Fall 1917

\title{
1917 Cedrus Yearbook
}

\section{Cedarville College}

Follow this and additional works at: https://digitalcommons.cedarville.edu/yearbooks

Part of the Higher Education Commons, Organizational Communication Commons, and the Public Relations and Advertising Commons

\section{Recommended Citation}

Cedarville College, "1917 Cedrus Yearbook" (1917). Yearbooks. 85.

https://digitalcommons.cedarville.edu/yearbooks/85

This Book is brought to you for free and open access by DigitalCommons@Cedarville, a service of the Centennial Library. It has been accepted for inclusion in Yearbooks by an authorized administrator of DigitalCommons@Cedarville. For more information, please contact digitalcommons@cedarville.edu. 


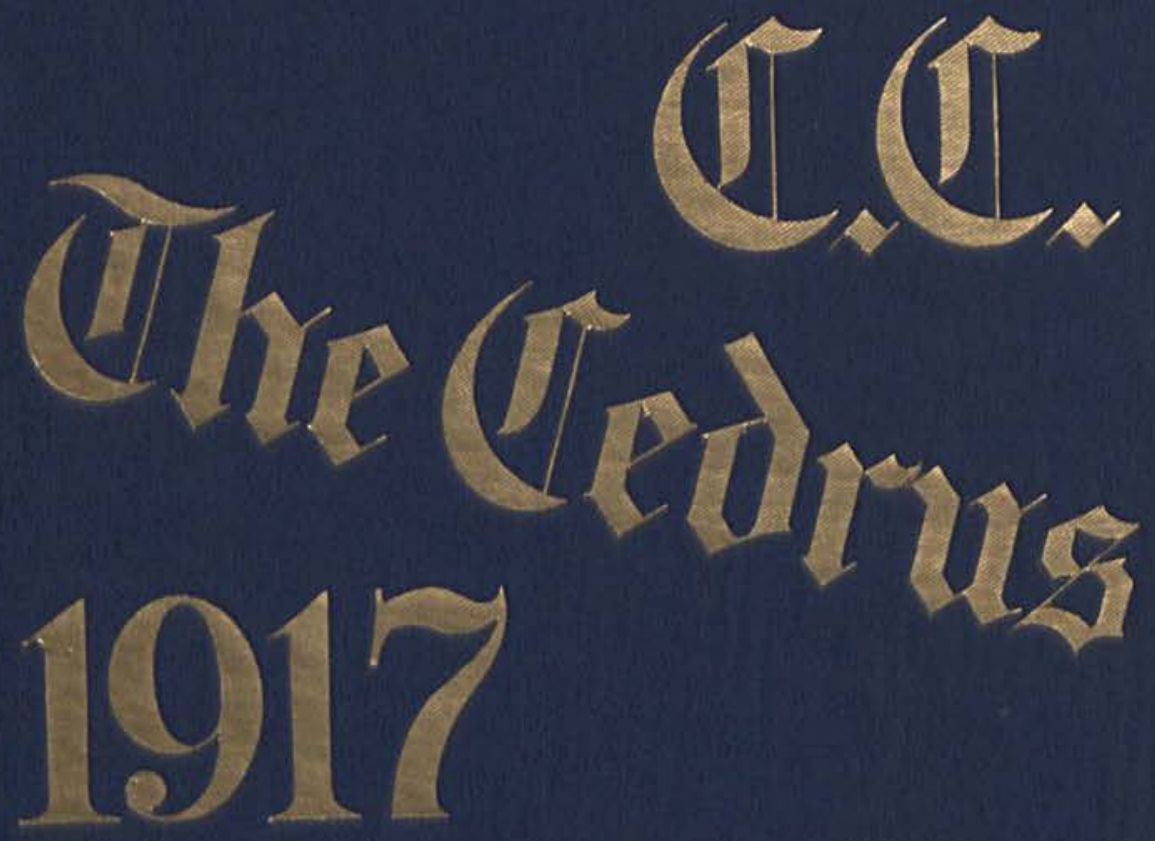




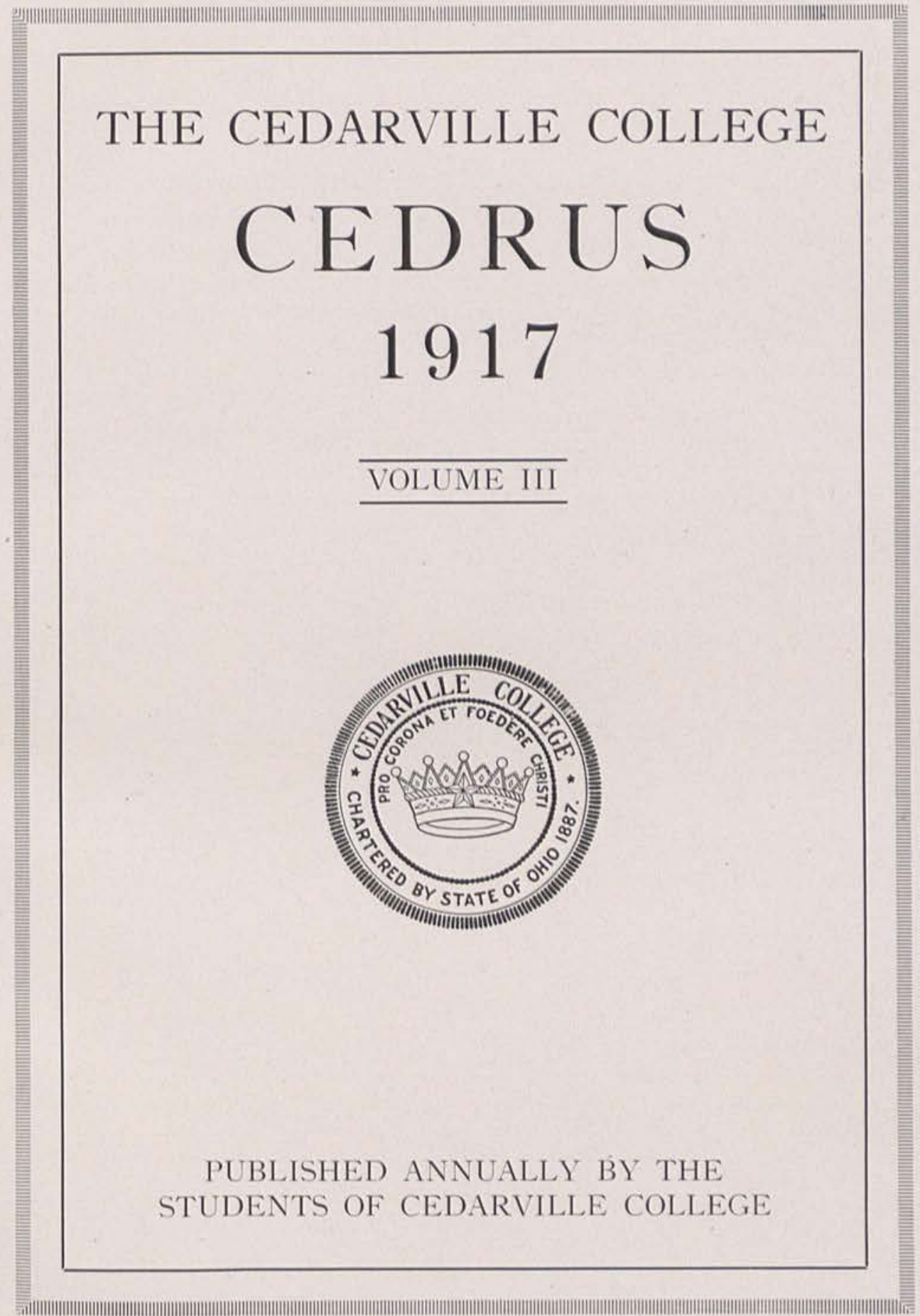




\section{Dedication}

TO Professor Frank A. selfish devotion and intense interest in student affairs and activities have won for him the love and confidence of the entire student body, this Cedrus is respectfully dedicated. 


\section{Introduction}

T $T^{\mathrm{E}}$ present to you with our greeting and good will this 1917 Cedrus. We trust you may find pleasure in the perusal of its pages, through which we have endeavored to give you a true insight into the life and spirit of the school.

We greatly appreciate the valuable assistance of the Faculty, and the hearty co-operation of fellow students. Space does not permit us to begin to extend complimentary notice to all who have contributed materially to the success of the Cedrus. We wish especially to thank the advertisers who have, by their patronage, aided us very substantially in financing this venture.

It has been our intention to please all; how well we have succeeded we of course cannot know. We certainly hope that our readers will find nothing to offend, somethings to amuse, and much to please and be treasured up in the years to come as reminders of the pleasant days we have all spent together, while endeavoring to fit ourselves for the greater activities which will soon be upon us.

THE STAFF. 

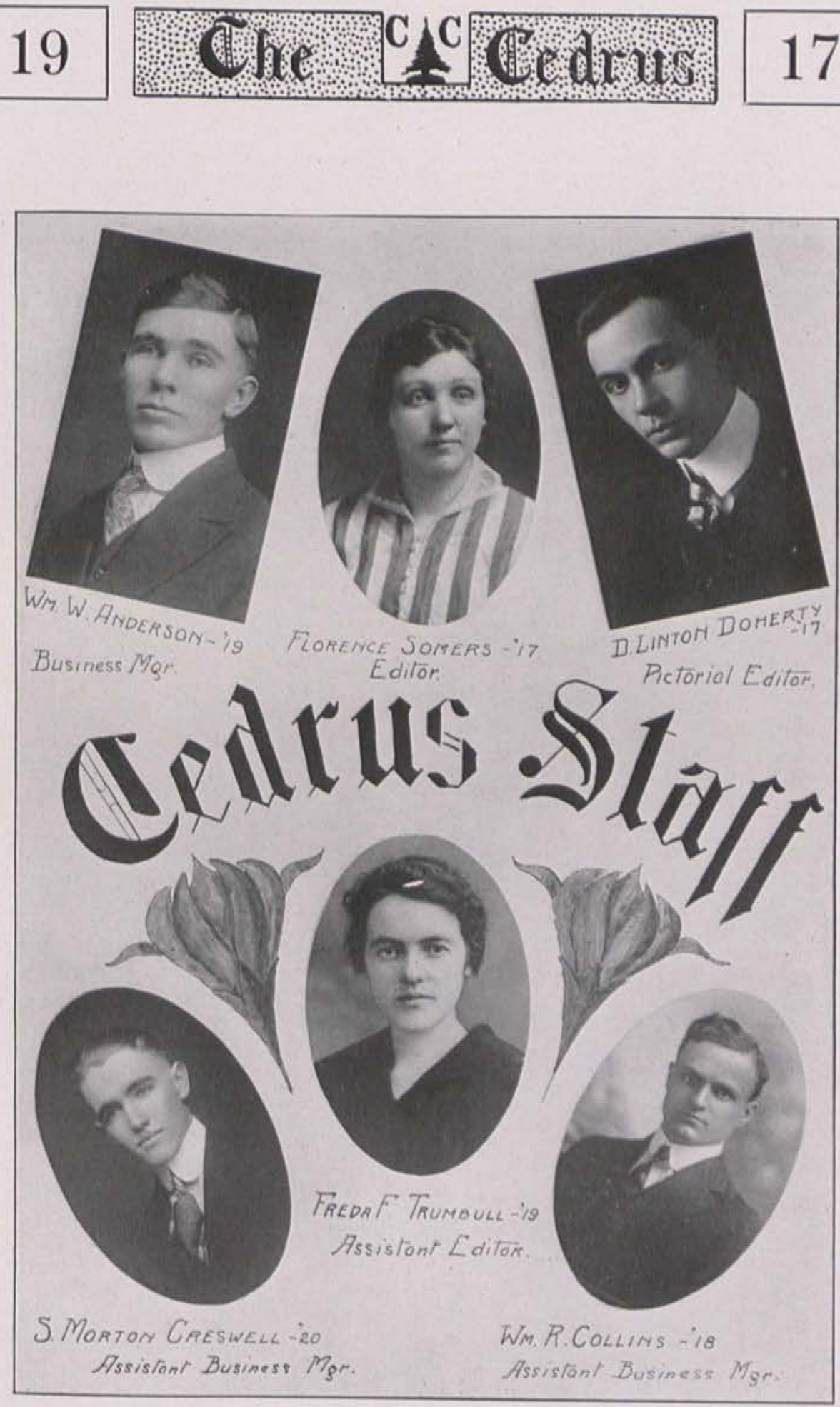


\section{9}
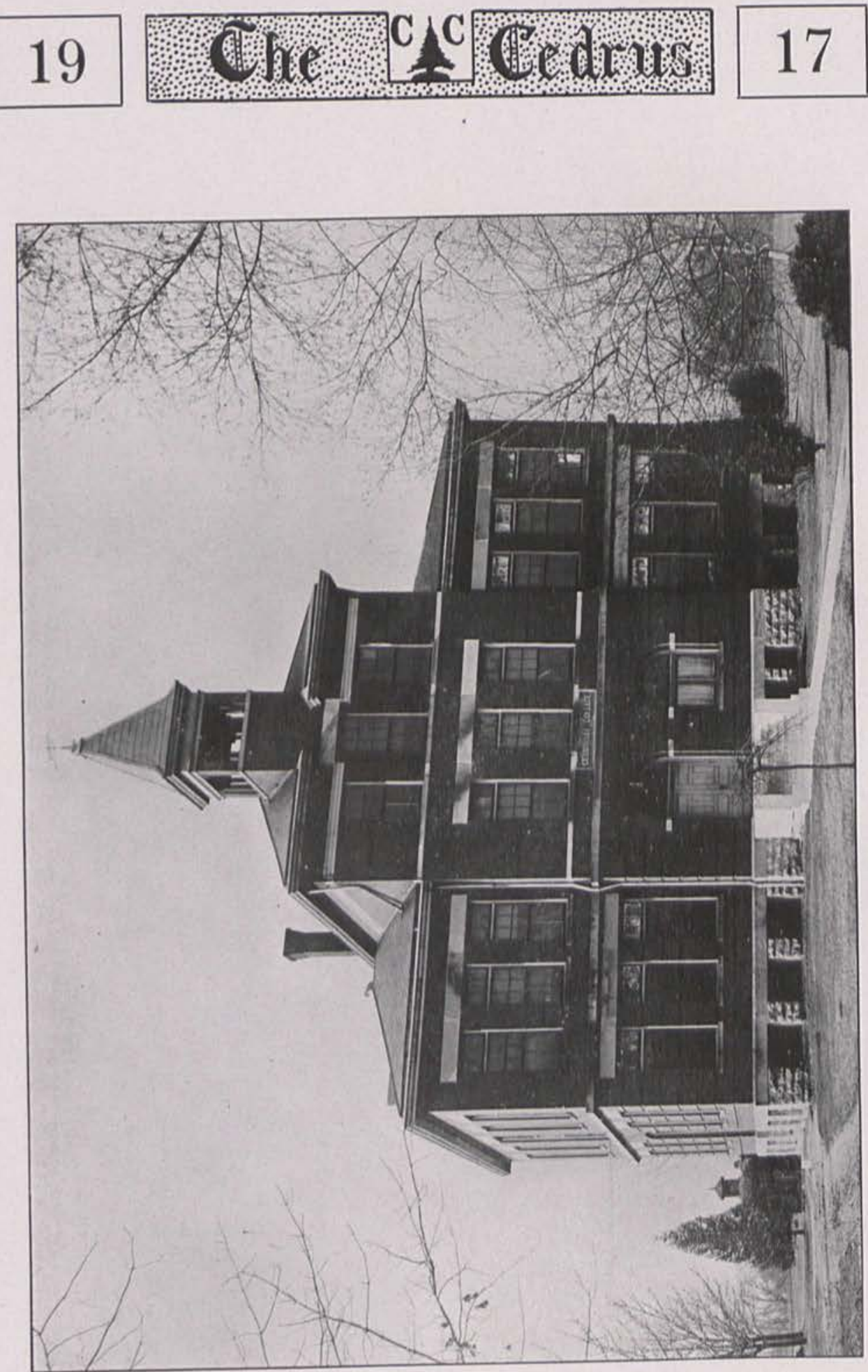

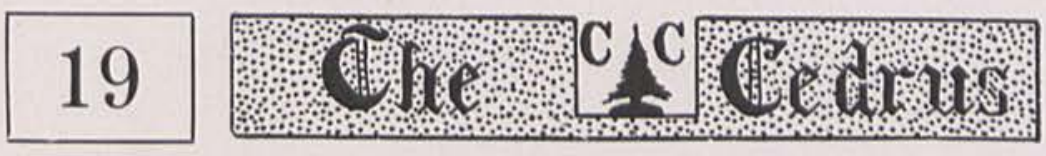

\section{Cedarville College History}

$\mathrm{C}$

EDARVILLE COLLEGE was chartered in January, 1887. It was opened for instruction, September 19, 1894, in the residence formerly owned by Rev. Hugh McMillan, D. D., where, half a century ago, he conducted an academy. In the second year the present main building was erected and entered. Rev. David McKinney, D. D., L. L. D., was the first president, and acted in this capacity for twenty-one years. Rev. Wilbert Renwick McChesney, Ph. D., D. D., was the first professor of the new college, and in 1915 succeeded Dr. McKinney as president.

The college is just completing its first $\$ 100,000$ of endowment and is starting on a campaign for the second $\$ 100,000$. We appeal to all who would invest their means for character, humanity, and the glory of God to give now to the endowment fund of Cedarville College. Sums small or large will be thankfully received and conscientiously applied as the giver directs. The following funds make up the endowment on hands:-

Peter Gibson . ........... \$20000 Thomas Gibson. ........... \$5000

Robt. M. Cooper ........ 4000

Friends ................. 7000

McLeod Memorial . .......... 8200

Saml. Price............... 3000

Philadelphia........... 5000

Alumni.................. $\quad 740$

A Friend ............... 5000

W. P. Haines . . . . 181.25

G. W. \& Mrs. Harper . . . . . 5000

James Burney Lyons ............ 700

Pittsburg................ 8000

Margaret A. Hunter. . . . . . . . . . 2000

George W. Brownell: ............ 200

Darlington .................. 1750

Friends . . . . . . . . . . . . 5190.75

Cincinnati Building. . . . . . . . . 20000

Teas Estate ................. 3800

The property and buildings in Cedarvile ase valut at sio0on. The Theological Seminary in logical Seminary in connection with the college has an endowment of $\$ 60000$.

Twenty classes of young men and women have been graduated totalling 181 alumni. These are located in 21 states and foreign countries, and are in all callings of life.

The college is recognized by Ohio State University and by the Department of Public Instruction of the State of Ohio, and by practically all of the leading universities.

In the summer of 1915 a summer school was added to the other lines of work offered by the college. The college and summer school offer all subjects taught in the modern first-class colleges. High scholarship, equal privileges, independent thought, and Christian character are the aims of Cedarville College.

The institution has three buildings, viz., College Hall, Alford Memorial Gymnasium, and Carnegie Library.

The location is beautiful, healthful and well-suited to the purposes of education.

The community is exceptionally moral and Christian in tone and loyal and devoted to the college.

The cost of an education in Cedarville is reasonable enough to be within the reach of all.

The atmosphere of the institution is democratic and congenial.

Its work is equal to that of colleges of high standing and receives the recognition and commendation of institutions and people of note. 


\section{9}

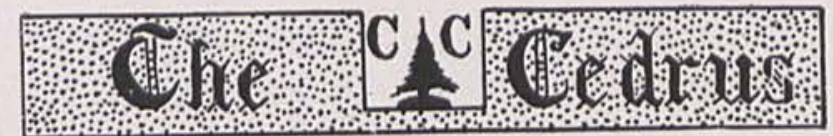

17

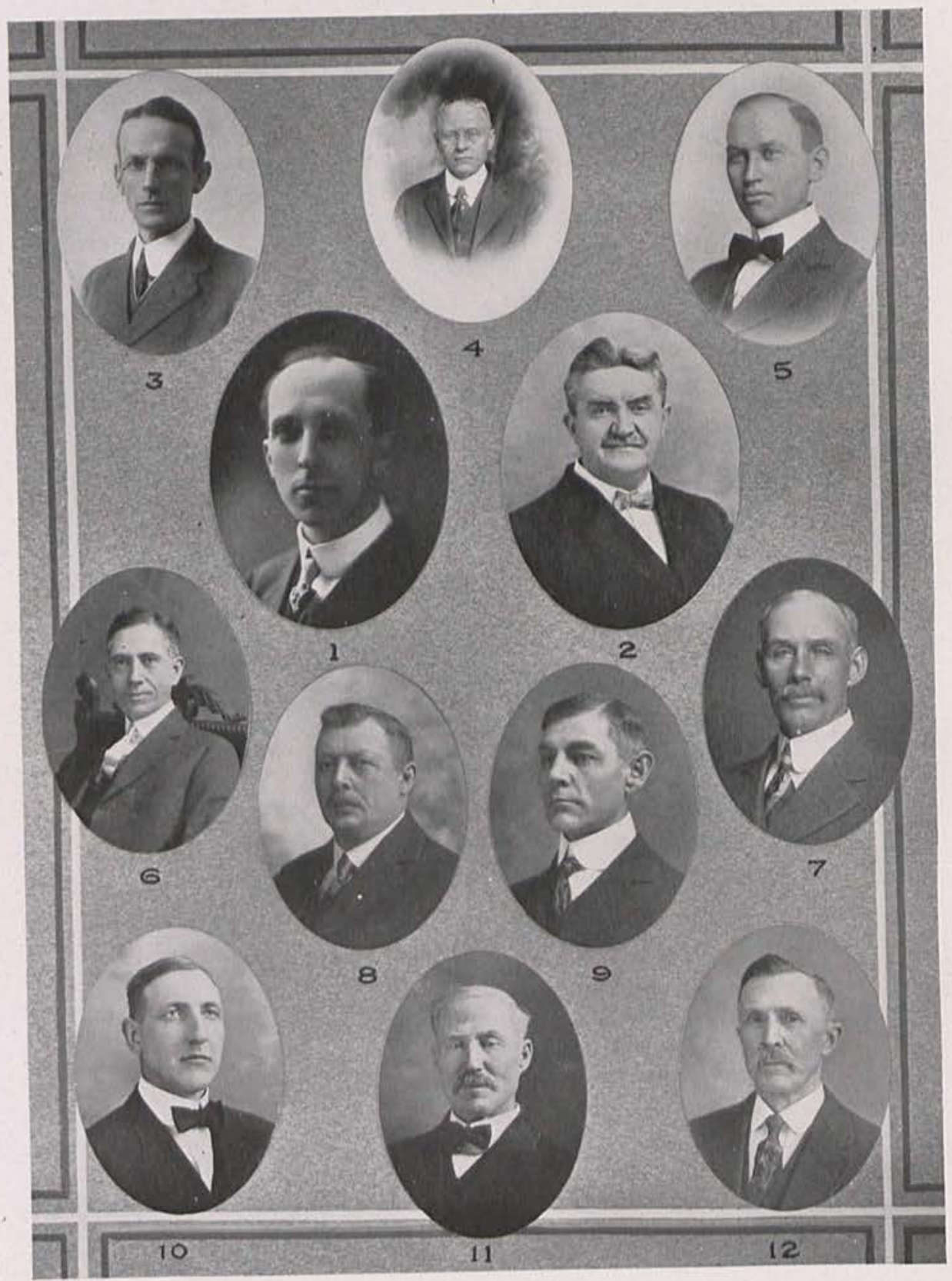




\section{9}

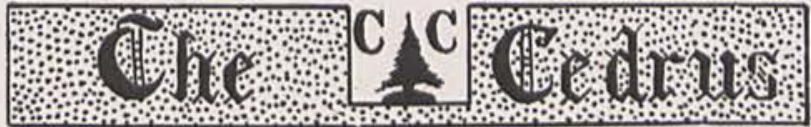

\section{Board of Trustees}

1. Rev. William R. Graham, A. B., '05, President

2. Rev. J. L. Chesnut, D. D., Secretary

3. Rev. Homer MeMillan, D. D.

4. Rev. David McKinney, D. D., L. L. D., A. B., '97

5. Joseph A. Finney, A. B., '06

6. Rev. W. R. McChesney, Ph. D., D. D.

7. J. H. Stormont *

8. O. E. Bradfute, First Vice President

9. Prof. S. C. Wright, A. B., '03

10. Prof. Frank A. Jurkat, A. M., Treasurer

11. James H. Creswell

12. Nathan L. Ramsey, Second Vice President

*Died October 23, 1916

\section{Women's Advisory Board}

$\mathrm{B}$

EAUTIFUL surroundings inspire one to think beautiful thoughts. This is what the Women's Advisory Board had in mind, when it organized in 1910. During the seven years of its existence, it has done much in beautifying the interior of College Hall. We feel that few organizations have contributed more to the welfare of the college than the Women's Advisory Board. 


\section{9}
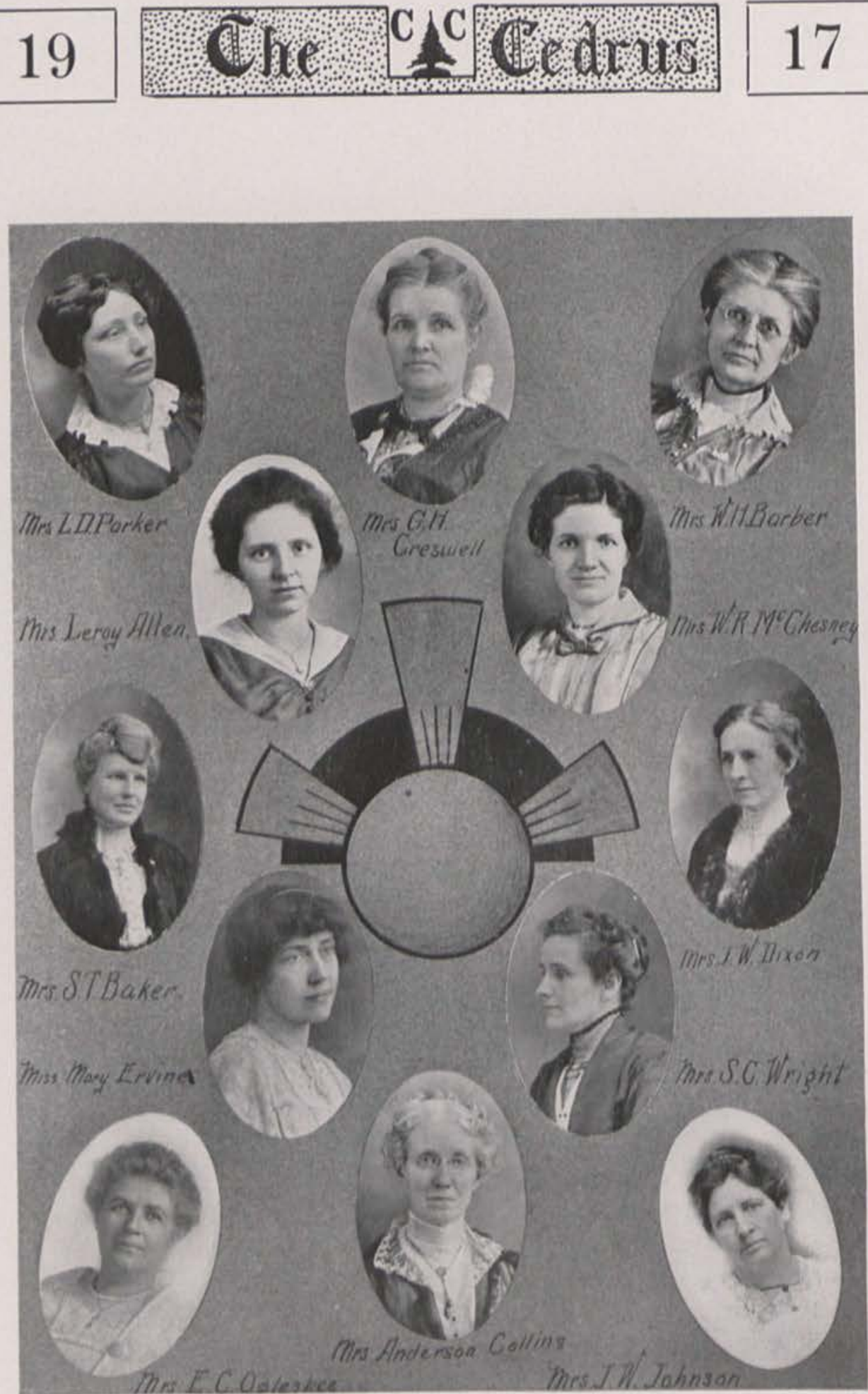


\section{9

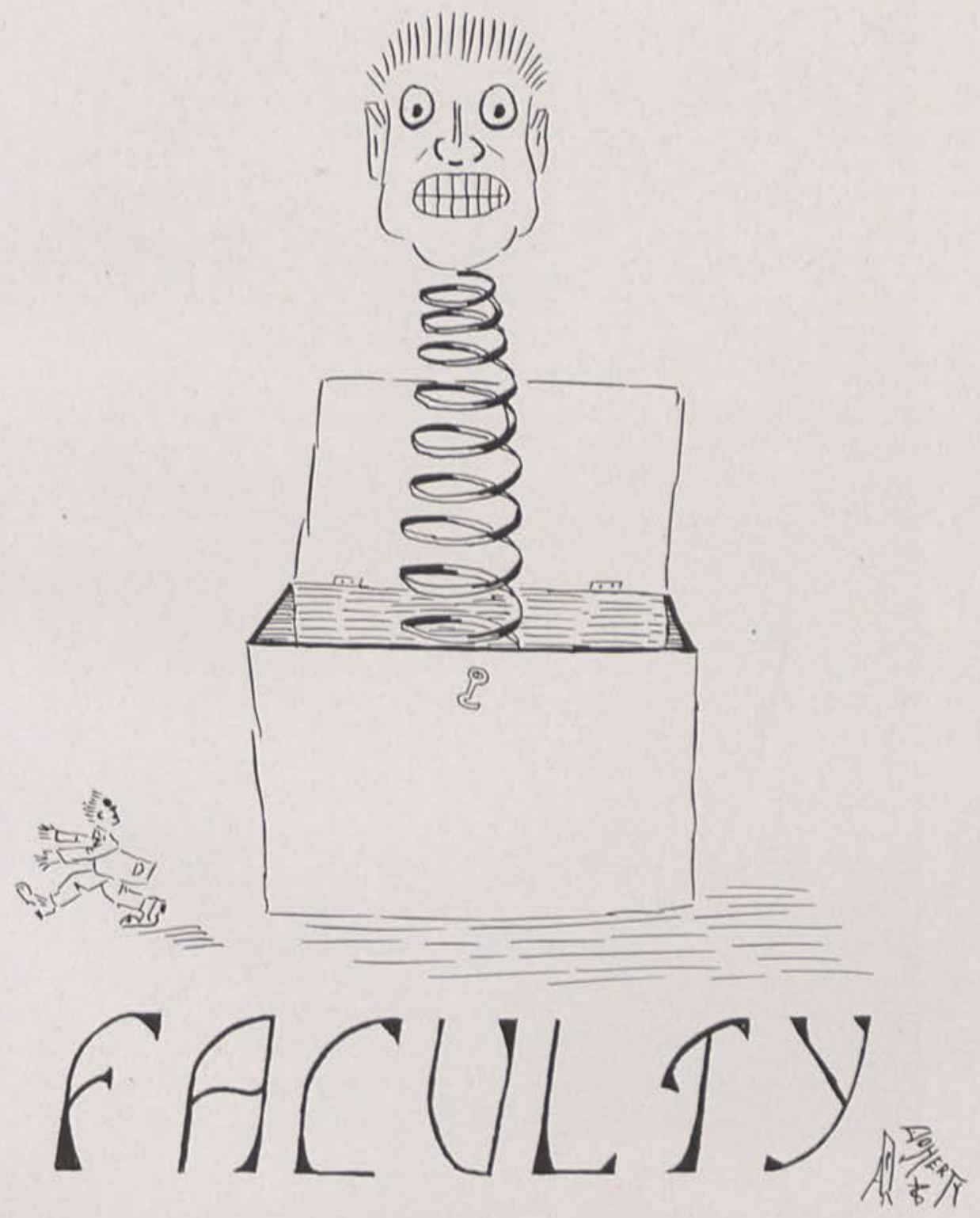




\section{9}
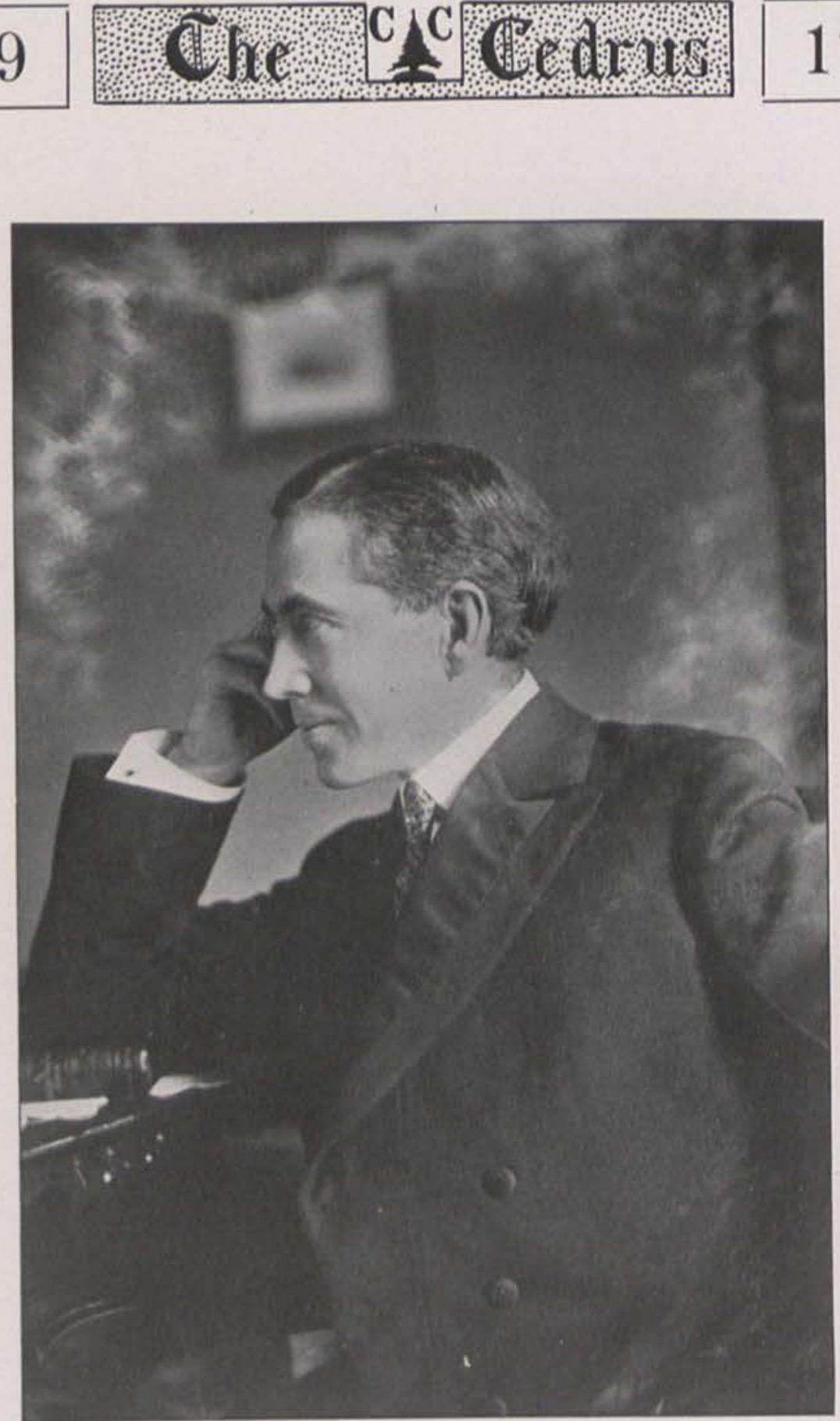

W. RENWICK MCCHESNEY President

Peter Gibson Professor of Psychology, Oratory and Greek. A. B., Franklin College, 1892; A. M., Franklin College, 1894; $\mathrm{Ph}$. D., Franklin College, D. D., Tarkio College, 1914. 


\section{9

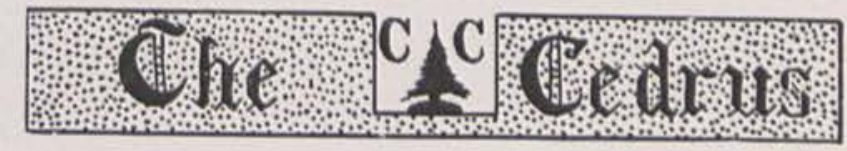

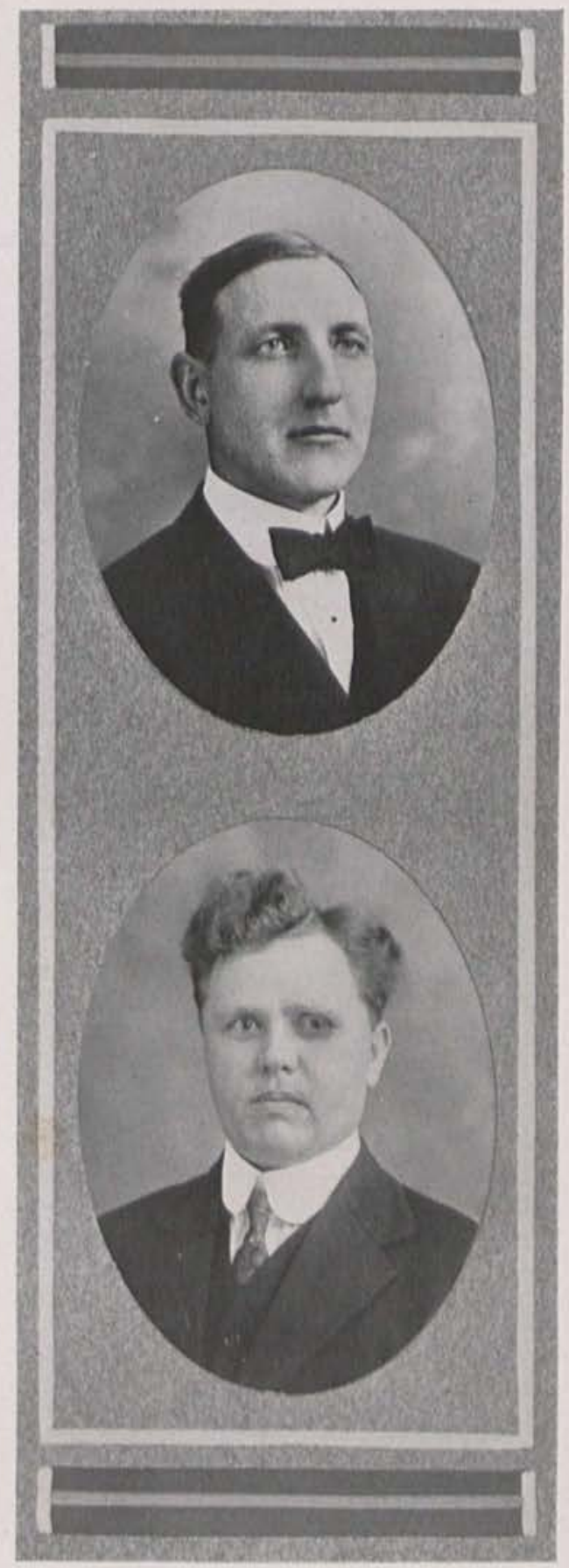

Frank Albert Jurkat.

Treasurer

Professor of Modern Languages,

Hebrew and History

A. B., Franklin College 1895.

A. M., Franklin College 1898.

\section{Leroy Allen \\ Dean}

Harper Professor of Economics and Sociology

Ph. B., Wooster University 1906.

Xenia Seminary 1914.

Attended summer sessions at Wisconsin and Chicago Universities. 


\section{9}
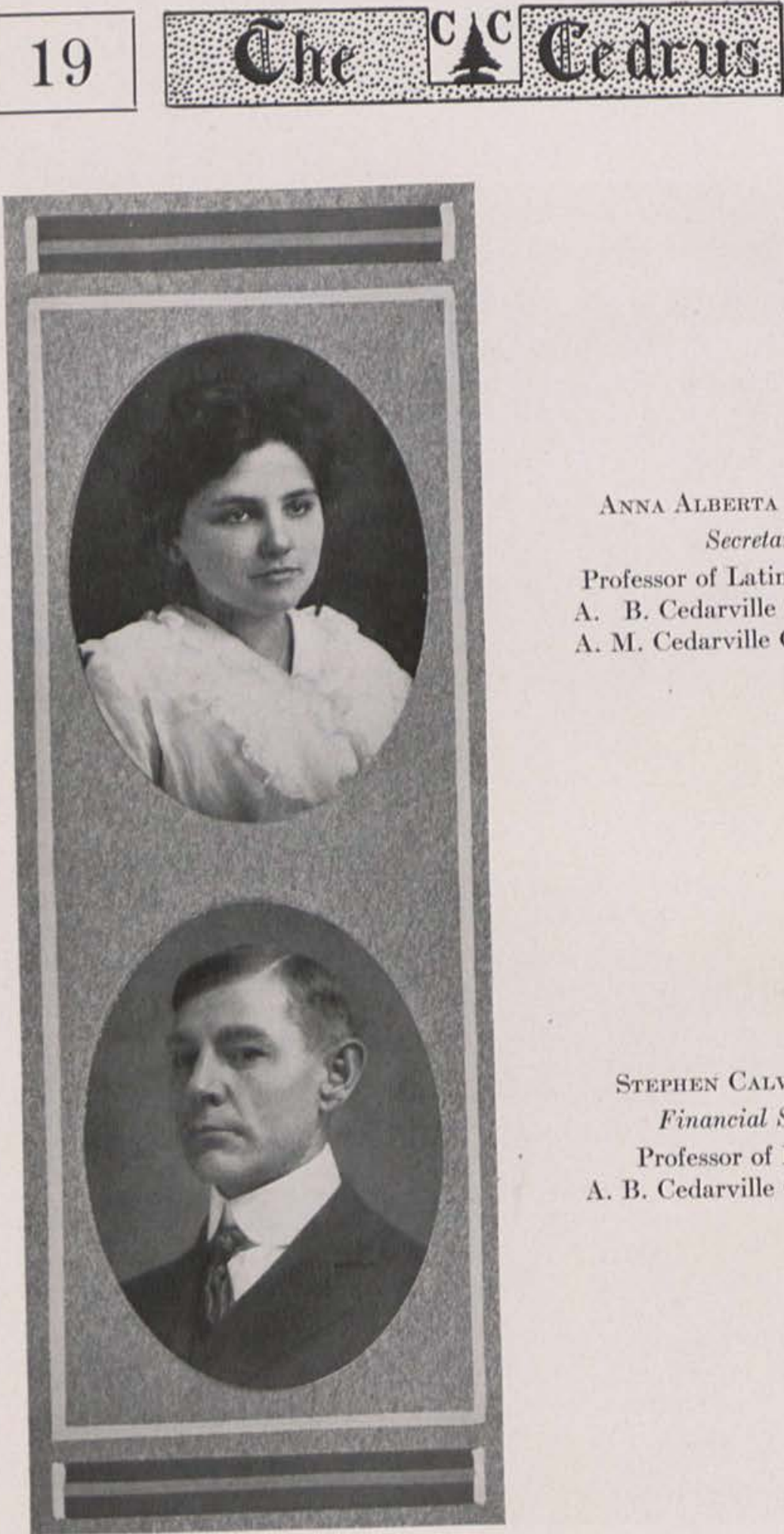

Anna Alberta Creswell Secretary

Professor of Latin and French A. B. Cedarville College 1910.

A. M. Cedarville College 1911

Stephen Calvin Wright

Financial Secretary

Professor of Education

A. B. Cedarville College 1908. 

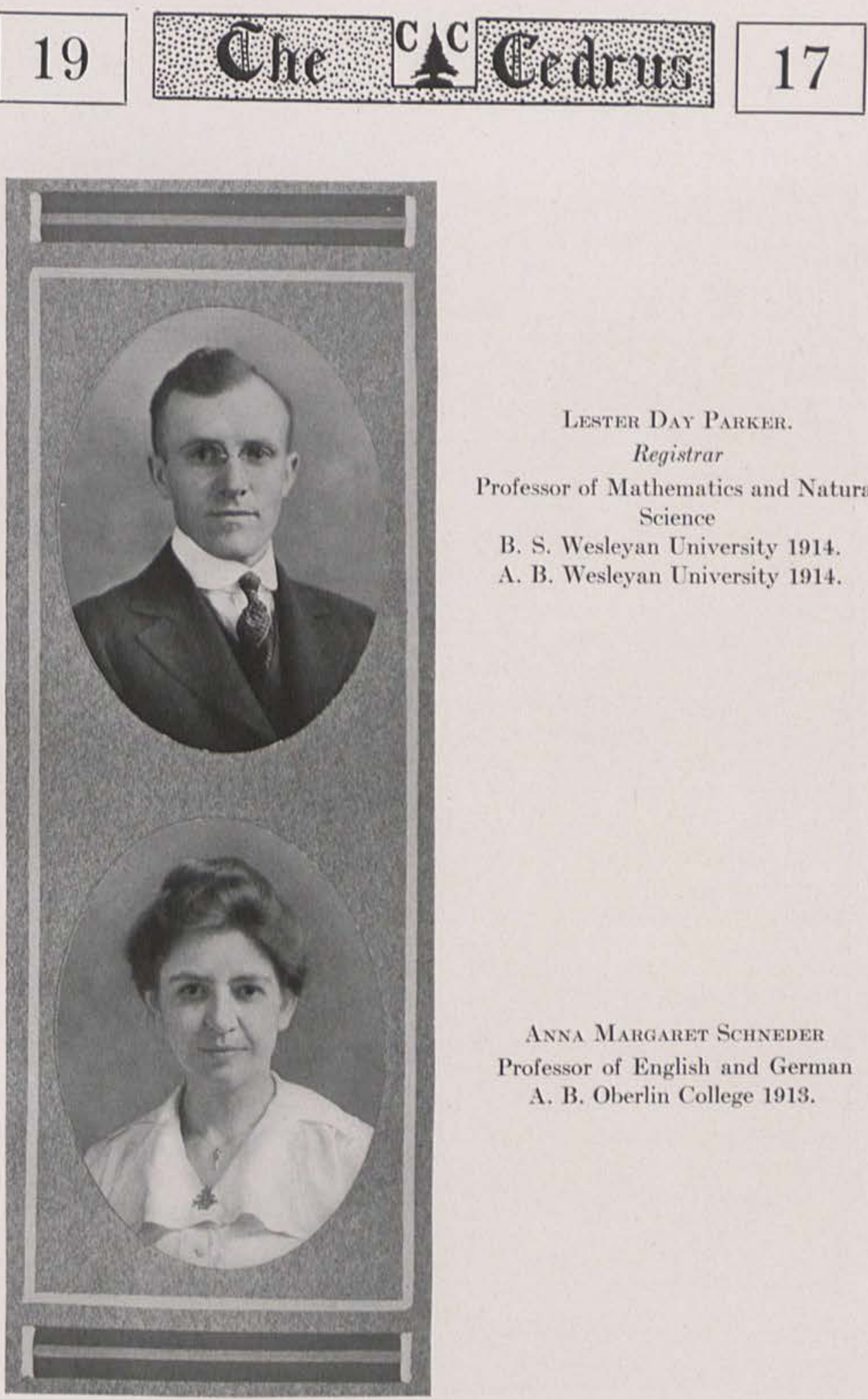

Lester Day Parker.

Registrar

Professor of Mathematics and Natural Science

B. S. Wesleyan University 1914.

A. B. Wesleyan University 1914.

Anna Margaret Schneder

Professor of English and German

A. B. Oberlin College 1918. 


\section{9}

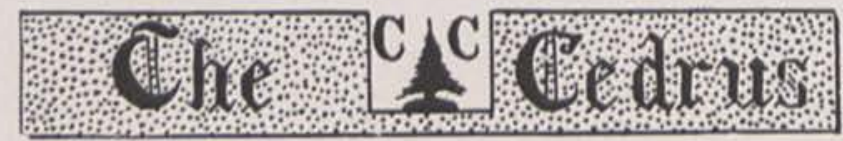

17

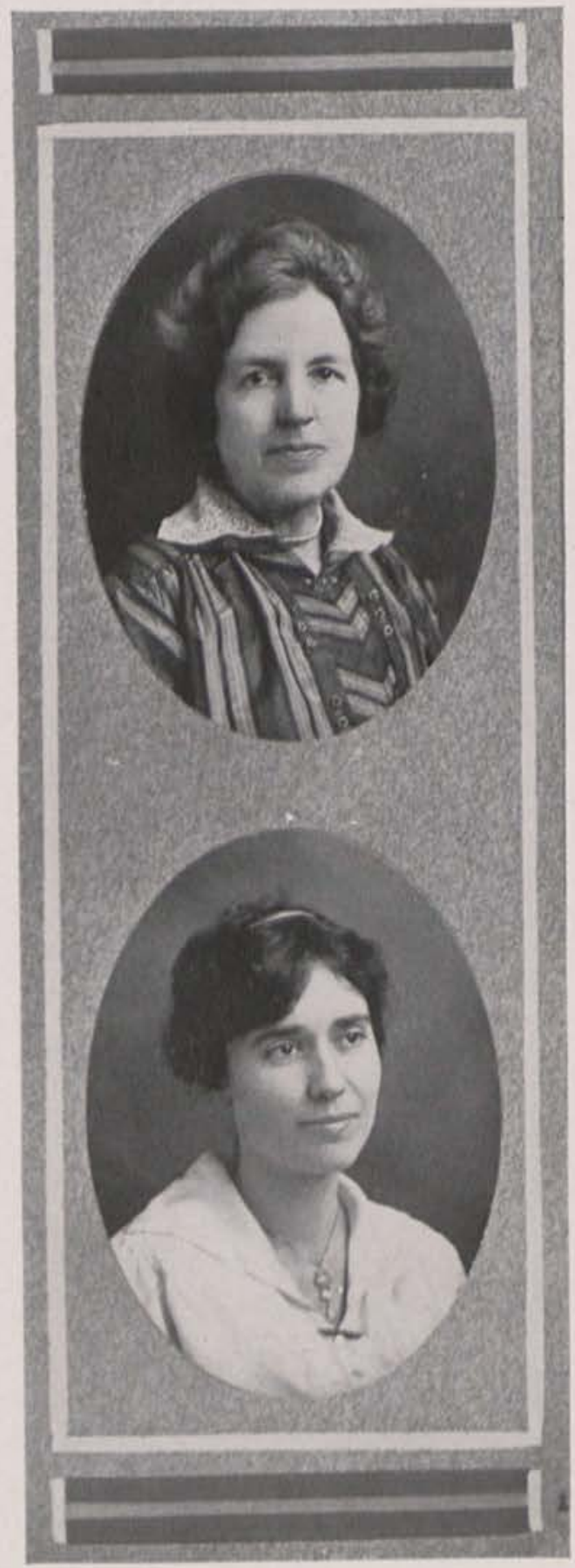

Mrs. Jessie Russell

Director of the Department of Music Professor of Music

Lorena Belle TAylor

Instructor in Household Economy

B. S. in H. E. Kansas State Agricultural College

Kansas, 1914. 

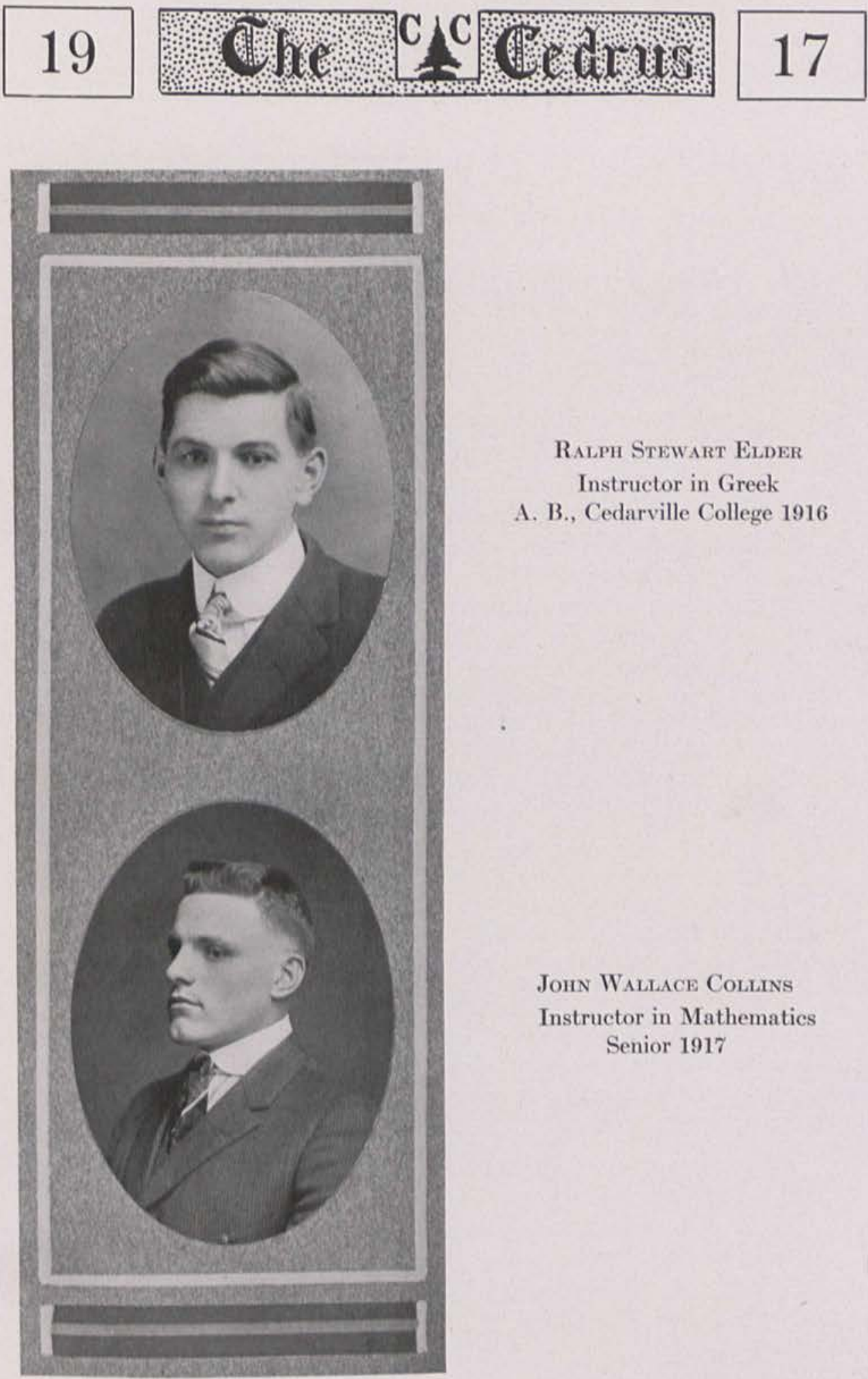

RaLPh Stewart Elder

Instructor in Greek

A. B., Cedarville College 1916

John Wathace Coluins

Instructor in Mathematics Senior 1917 


\title{
19
}

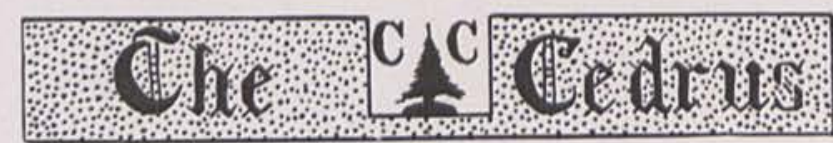

\section{"A Cedarville Contribution to the Cause of Patriotism"}

\author{
By Wilbur D. Nesbit *
}

\section{“ Paur Jflag and ftly fflag."}

Your flag and my flag,

And how it flies today

In your land and my land and half a world away.

Rose red and blood red

The stripes forever gleam

Snow white and soul white,

The good forefathers' dream.

Sky blue and true blue,

With stars to gleam aright;

The gloried guerdon of the day,

A shelter thru' the night.

Your flag and my flag,

To every star and stripe

The drums beat as heart beat and fifer's shrilly pipe.

Your flag and my flag,

A blessing in the sky.

Your hope and my hope,

It never hid a lie.

Homeland and far land and half the world around

Old Glory hears our glad salute

And ripples to the sound.

Your flag and my flag,

And oh, how much it holds;

Your land and my land secure within its folds.

Your heart and my heart

Beat quicker at the sight.

Sun-kissed and wind-tossed

The red, the blue and white;

The one flag, the great flag, the flag for me and you.

Glorified all else beside

The red, the white, the blue.

* Mr. Nesbit is a native of Cedarville. He was born here September 16, 1871.

Copyrighted by P. F. Volland \& Co., Chicago. Used and printed by permission of the publishers. 


\section{Che AC Codrus 17}

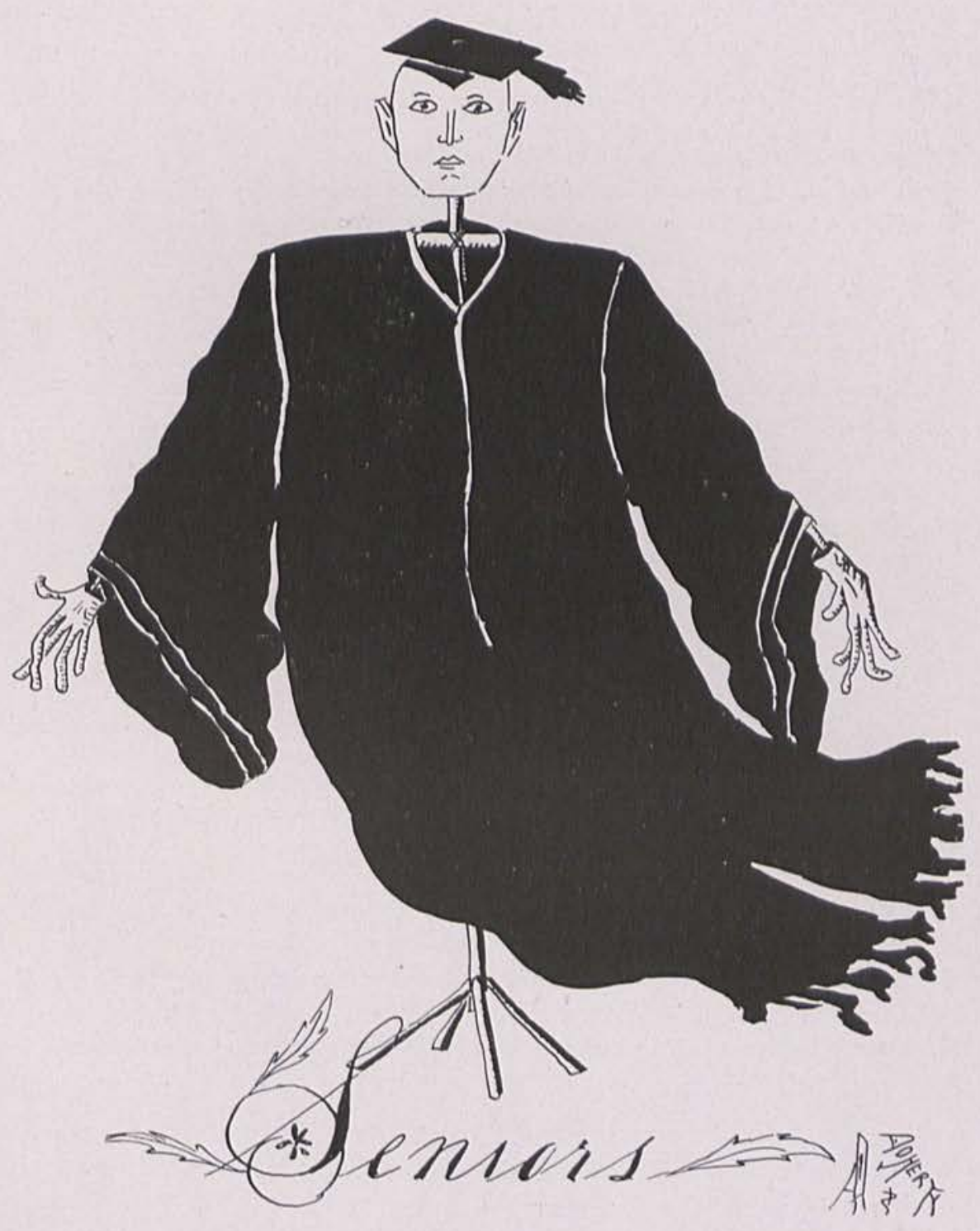




\section{9}

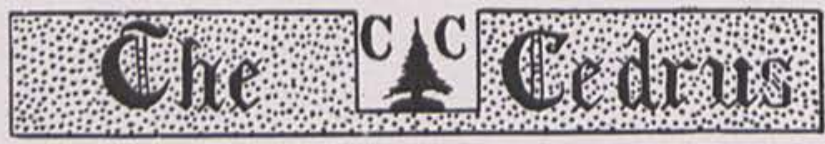

\section{Senior Affirmative Brief}

Proposition: Resolved that the class of 1917 is the best class that has ever trod the halls of Cedarville College.

\section{INTRODUCTION}

I-Statement of Admitted matter. A-There have been and are other classes with some members of ability. $\mathrm{B}-\mathrm{We}$ are not quite perfect.

II-Definition of terms.

A-The word, "best," implies that the class in question is of superior quality.

III-The question is therefore, "Is the class of 1917 the best class that ever trod the halls of Cedarville College.”

\section{The Affirmative answers YES, for}

A-The class of 1917 excels all other classes in weight.

B-The class of 1917 excels all other classes in scholarship.

C-The class of 1917 has better athletes than any other class.

D-The class of 1917 excels all other classes in good looks.

E-The class of 1917 excels all other classes in artistic temperament.
The Negative answers

$$
\text { NO, for }
$$

A-The class of 1917 does not excel all other classes in weight.

B-The class of 1917 does not excel all other classes in scholarship.

C-The class of 1917 does not have better athletes than any other class.

D-The class of 1917 does not excel all other classes in good looks.

E-The class of 1917 does not excel all other classes in artistic temperament.

IV-Through this clash of opinion we reach the following issues.

A-Does the class of 1917 excel all other classes in weight?

B-Does the class of 1917 excel all other classes in scholarship?

C-Does the class of 1917 have better athletes than any other class?

D-Does the class of 1917 excel all other classes in good looks?

E-Does the class of 1917 excel all other classes in artistic temperament?

\section{PROOF}

I-The class of 1917 excels all other classes in net weight, for

A-The total weight of the class is one ton, for

1. John Collins weighs 225 pounds.

2. Florence Somers weighs 195 pounds.

3. Anna Collins weighs 190 pounds.

4. The total weight of other members is 490 pounds 


\section{9}

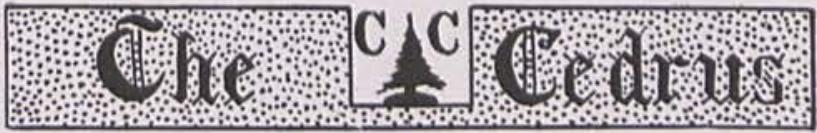

II-The class of 1917 excels all other classes in scholarship, for

1. Ruth Ramsay was never known to refuse to answer a question in class.

2. Donna Burns was never known to be late to a recitation.

3. Mary Chesnut even cuts chapel exercises that she may be better prepared on her lessons.

4. Mabel Stormont never received an average below 90 per cent.

III-The class of 1917 contains the best athletes of all the other classes, for

1. John Collins has played on every basket-ball and base-ball team in the college since his entrance.

2. Florence Somers played on the girls' basket-ball team 3 years.

3. Ruth Ramsay played on the girls' basket-ball team 2 years.

4. Donna Burns played on the girls' basket-ball team 3 years.

5. Anna Collins played on the girls' basket-ball team for 3 years.

6. Mabel Stormont played on the girls' basket-ball team for 2 years.

IV-The class of 1917 excels all other classes in good looks, for

A - Certain ones of the under-classmen have given their testimony, for

1. John Collins is considered the handsomest man in the college by a bonnie lassie. (Janet McClellan, Junior Class.)

2. David Doherty is considered the handsomest man in the college by a bonnie lassie. (Dorothy Smithson, Freshman Class.)

3. Anna Collins is considered the handsomest girl in the college by a bonny laddie. (Oliver Cornwell, Sophomore Class.)

B - There are two sets of beautiful dimples in the class, for

1. Every Collins has them.

$\mathrm{V}$-The class of 1917 excels all other classes in artistic temperament, for

1. Dave Doherty is the college artist.

2. Robert Hutchinson has taken unto himself a lovely wife.

3. Marie Payne and Mildred Trumbo are accomplished musicians.

4. Anna Collins is an accomplished singer.

\section{CONCLUSION}

I - Since the class of 1917 excels in weight;

II-Since the class of 1917 excels in scholarship;

III-Since the class of 1917 has the best athletes;

IV-Since the class of 1917 excels in good looks;

$\mathrm{V}$-Since the class of 1917 excels in artistic temperament;

Therefore the Class of 1917 is the best class that has ever trod the halls of Cedarville College. 


\section{9}

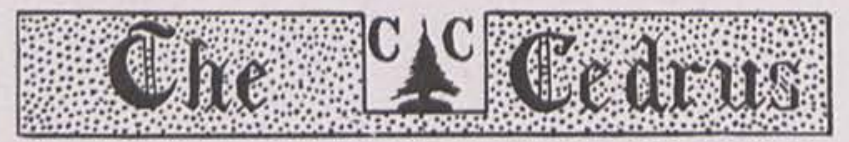

17

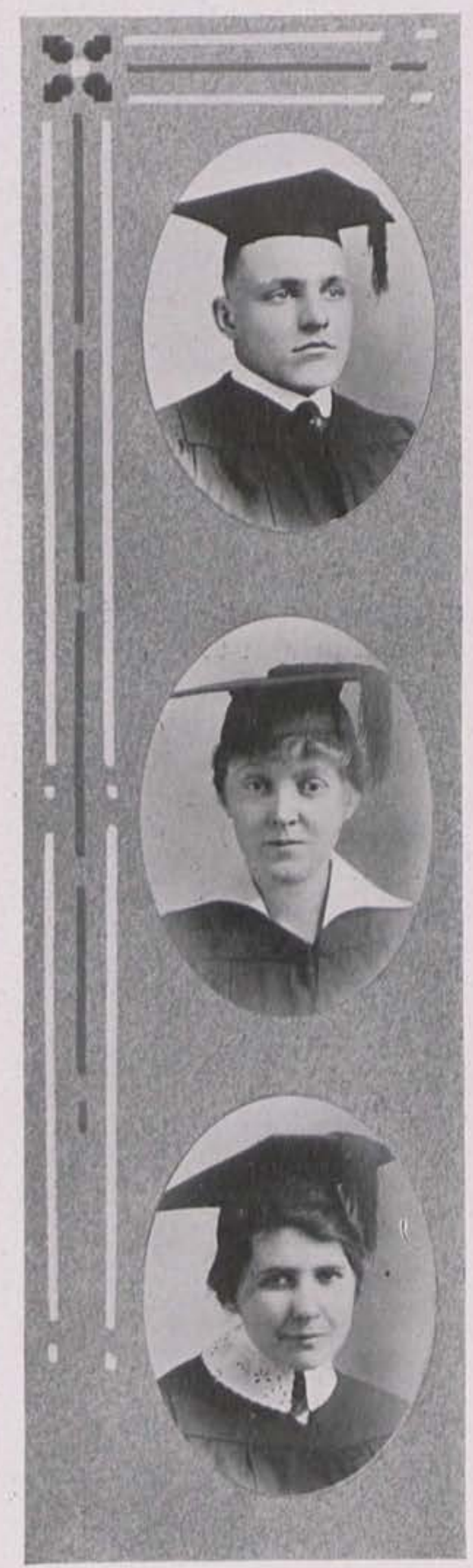

John Wallace Collins, A. B.

Home-Cedarville, Ohio.

Haunts - Usually found foraging in the pantry or warming his feet before Townsley's grate.

Habits - Studious and retiring.

Mary Elyzabeth Cheśnut, A. B.

Home-Cedarville, Ohio.

Haunts - Post-office, library, most anywhere.

Habits - Cutting Chapel. Prefers books to dates

Ruth Ramsey, A. B.

Home - Cedarville, Ohio.

Haunts-Usually found burning the midnight oil.

Habits - Takes things seriously. Often unexpectedly smiles. Writing to Amelia, Ohio. 


\section{9

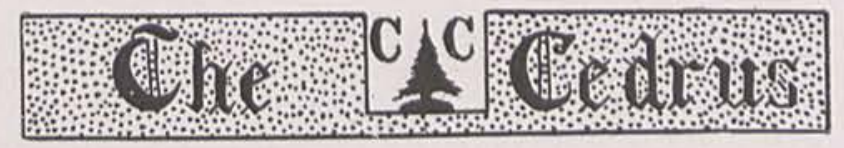

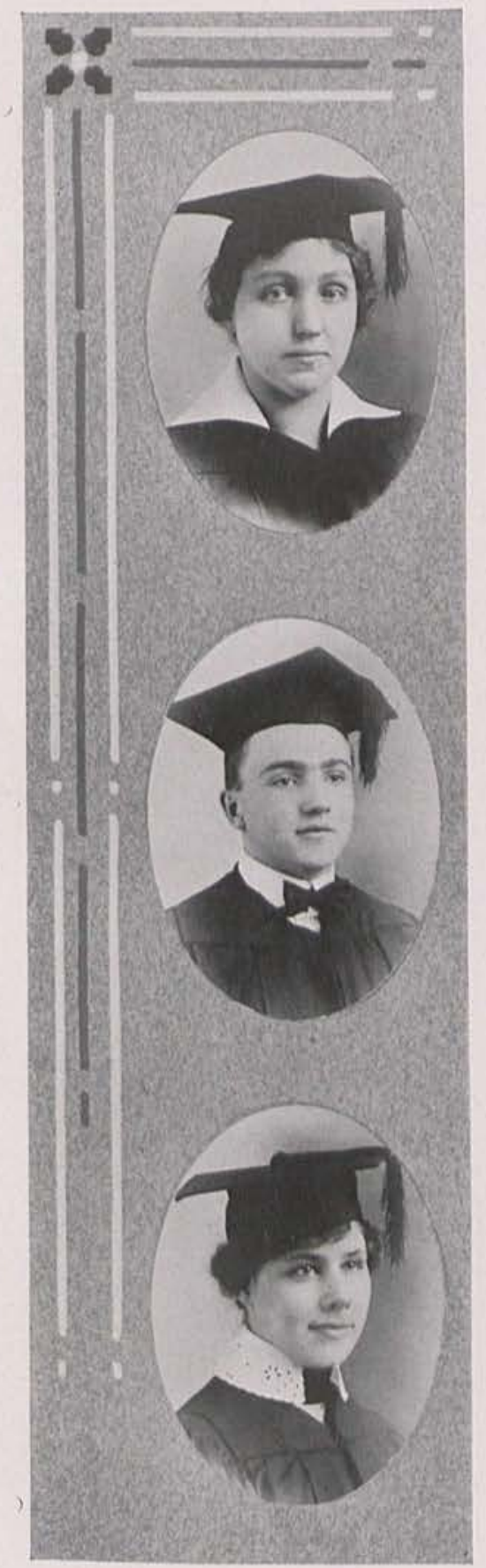

Florence Enid Somers, A. B.

Home-Republic, Ohio.

Haunts-At home, at the College sometimes, often down-town.

Habits-Reading anti-fat advertisements, writing for Cedrus, studying intermittently.

\section{Robert Linton Hutchinson}

Graduate student in Theology.

Home-Philadelphia, Pa.

Haunts - St. Johnsville, library seminary.

Habits-Loving his wife, drying dishes, feeding chickens.

Mabel Lillian Stormont, A. B. Home-Cedarville, Ohio.

Haunts - At home on the farm.

Habits - Often seen, seldom heard, never cuts classes or chapel. 


\section{9}
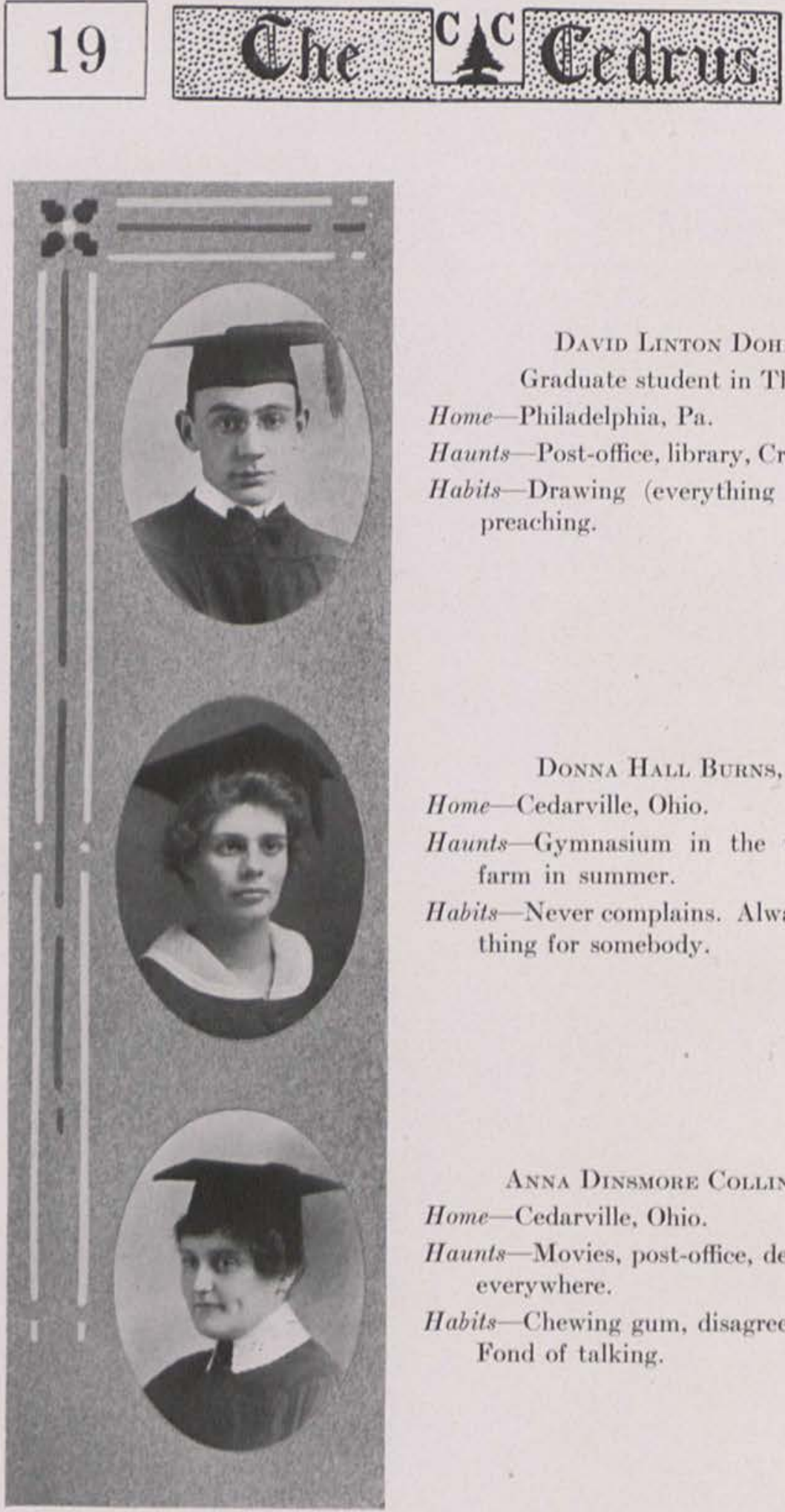

\section{David Linton Doherty}

Graduate student in Theology.

Home-Philadelphia, Pa.

Haunts - Post-office, library, Crawford's parlor.

Habits-Drawing (everything but a salary), preaching.

Donna Hall Burns, A. B.

Home - Cedarville, Ohio.

Haunts - Gymnasium in the winter, on the farm in summer.

Habits-Never complains. Always doing something for somebody.

Anna Dinsmore Collins, A. B.

Home - Cedarville, Ohio.

Haunts-Movies, post-office, depot restaurant, everywhere.

Habits - Chewing gum, disagreeing with Profs. Fond of talking. 


\section{9}
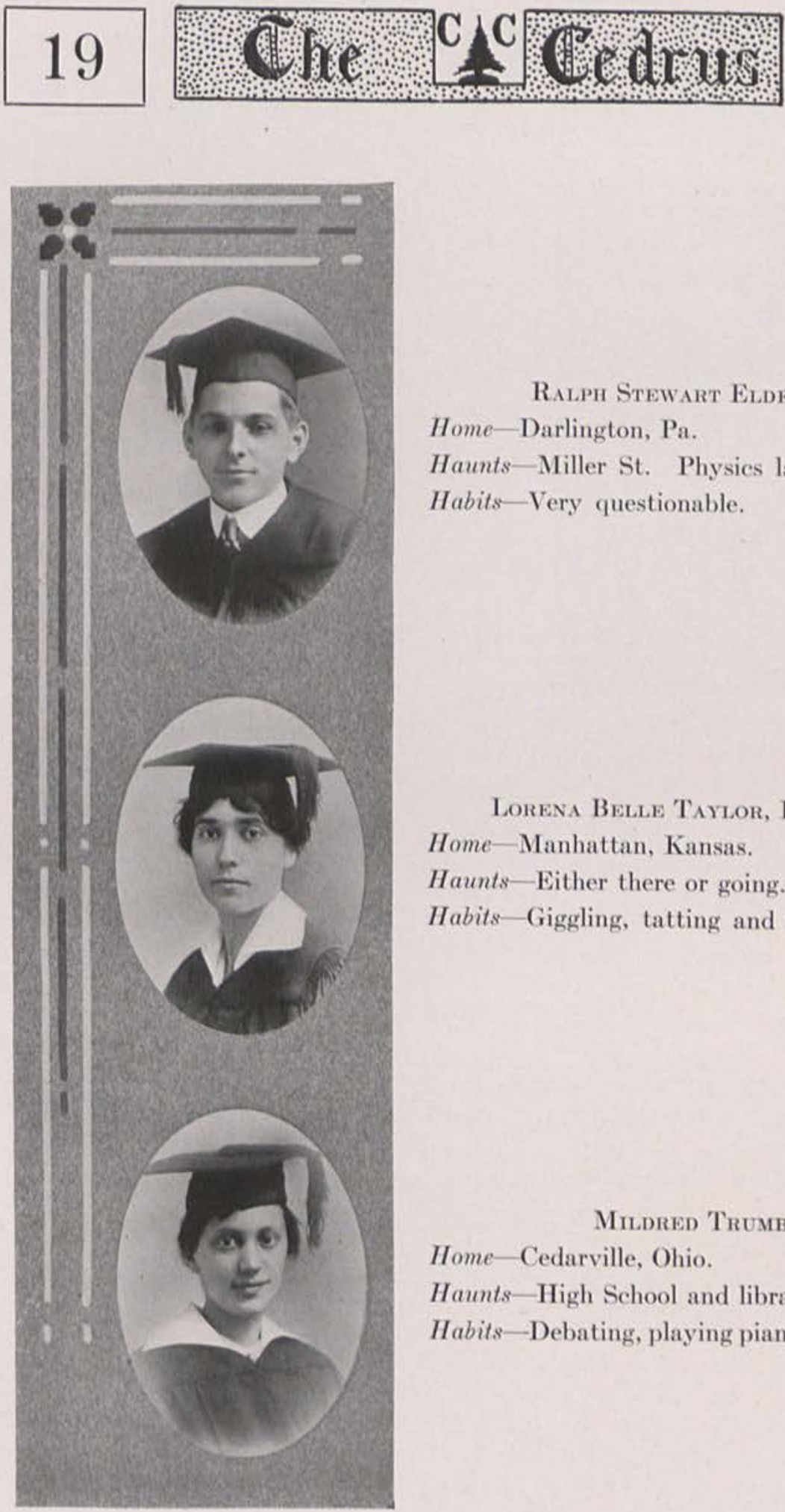

Ralph Stewart Eldeer, A. M. Home-Darlington, $\mathrm{Pa}$.

Haunts-Miller St. Physics laboratory. Habits-Very questionable.

Lorena Belle Taylor, B. S. in E. Home-Manhattan, Kansas. Haunts-Either there or going. Habits - Giggling, tatting and tattling.

Mildred Trumbo

Home Cedarville, Ohio.

Haunts-High School and library.

Habits - Debating, playing piano, very studious 


\section{9

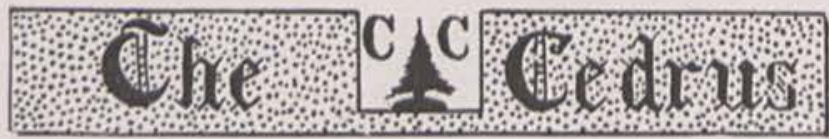

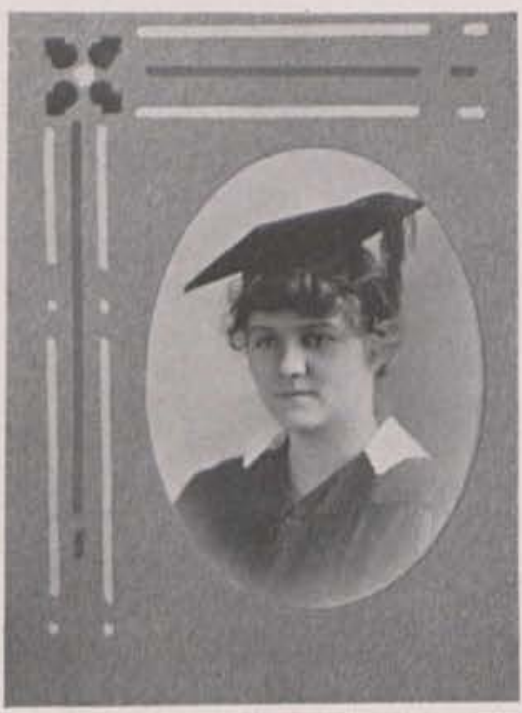

Mrs. Marte Payne

Home - Cedarville, Ohio.

Haunts - Kitchen and parlor.

Habits-Playing piano.

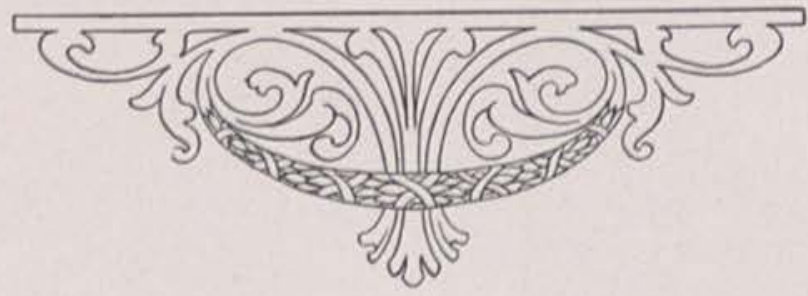




\section{9

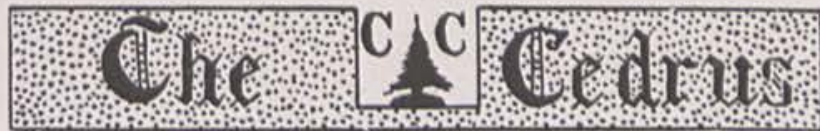 \\ 17}

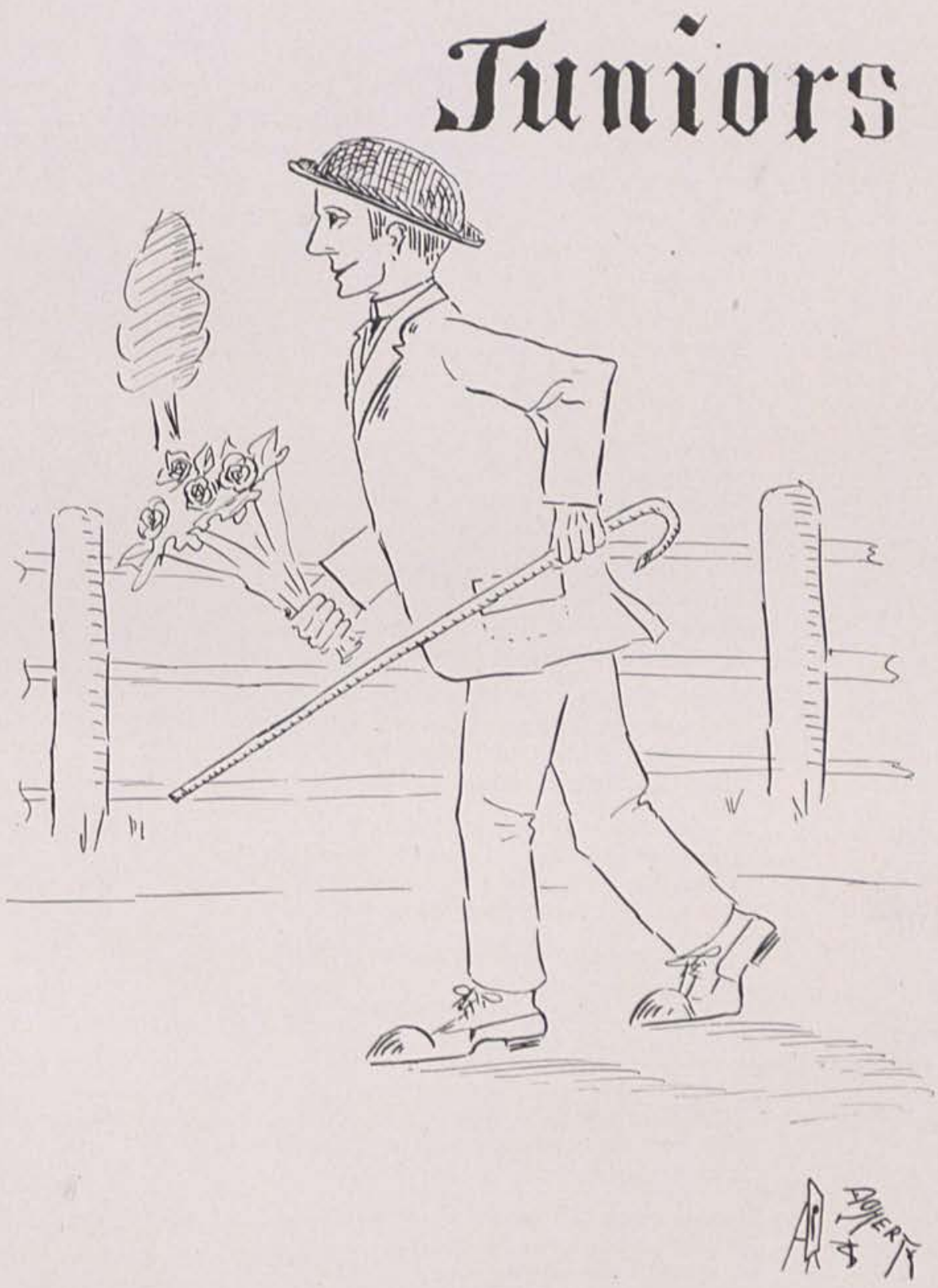




\section{Junior Jingles}

We know not what a day may bring;

The future's veiled from all;

So the past of the class of '18

We'll endeavor to recall.

So if you my gentle readers,

Will give me a little time,

I will tell you as I know it,

Our class history in rhyme.

The president of our worthy class,

Has received his share of fame,

On the basket-ball floor and class room too,

Bill Collins is his name.

When there is any music sought,

Our class is right there you see,

With a talented girl, you all have met,

Our own Helen Oglesbee.

A third classmate Ethel McCambell,

Is as quiet and good as you'll find;

She's always on time at classes,

Her books never left behind.

James Chesnut, an all around chap,

Is a special student of Greek,

A student of human nature too.

They say, seven nights in a week.

A girl whom every one adores,

For some joke she's always telling,

A scholar always busy at work,

Her name is Janet McClellan.

And should you seek an authoress,

We need not hesitate,

For Irene Wright would fill the place,

And do it up to date.

And then there is Tom Kennon,

Who is our athletic star,

The best natured man on the team they say,

And his praises are lauded afar.

Last on the list of these great names,

Is the tiniest one of our class,

A student of excellence and worth,

Olive Northup our country lass. 

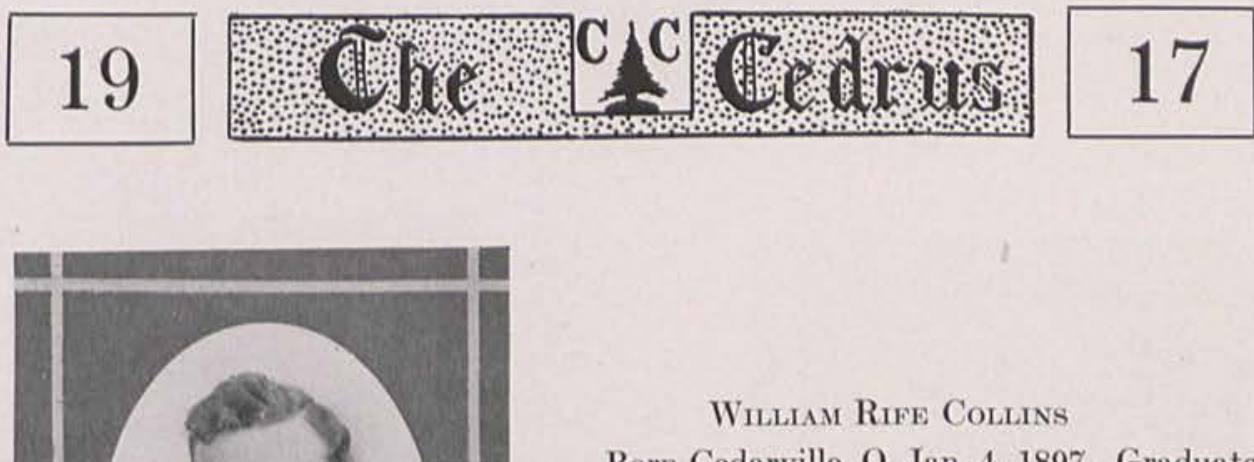

Born Cedarville, O. Jan. 4. 1897. Graduated Prep. Dept. 1914. Basket Ball '12-'17. President of the Class. Mgr. of Cedrus 1916. President Y. M. C.A.

"I have no secret of success but hard work."

\section{Helen Pauline Oglesbee}

Born Cedarville, O. Sept. 30, 1896. Graduated Ced. H. S. 1914. Graduated from C. C. in music 1914. Basket Ball 1916.

"Softly her fingers wander o'er

The yeilding planks of ivory floor."

\section{NAOMI Irene Wright}

Born Idaville, Ind., August 14, 1896. Graduate Ced. H. S. 1914. Basket Ball '15-'17.

"And to her eyes there is but one beloved face on earth." 


\section{9}

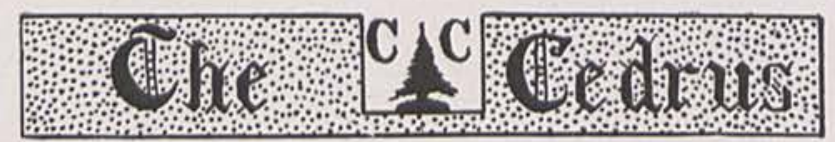

17

\section{Janet Eliza McClellan}

Born Xenia, O., Aug. 24, 1894. Graduated Beaver Creek H. S. 1911. Basket Ball '15-'17. President Y. W. C. A. 1917. President of Philosophic Literary Society 1916.

"Blest with a good reason and sober sense."

\section{- Carrie Olive Northup}

Born Clifton, O., March 5, 1897. Graduated Clifton H. S. 1914. Treasurer Y. W. C. A.

"Good nature is the beauty of the mind."

Mary Ethel McCampbell

Born Cedarville, O., Aug. 8, 1895.

"How poor are they who have no patience." 


\section{9}
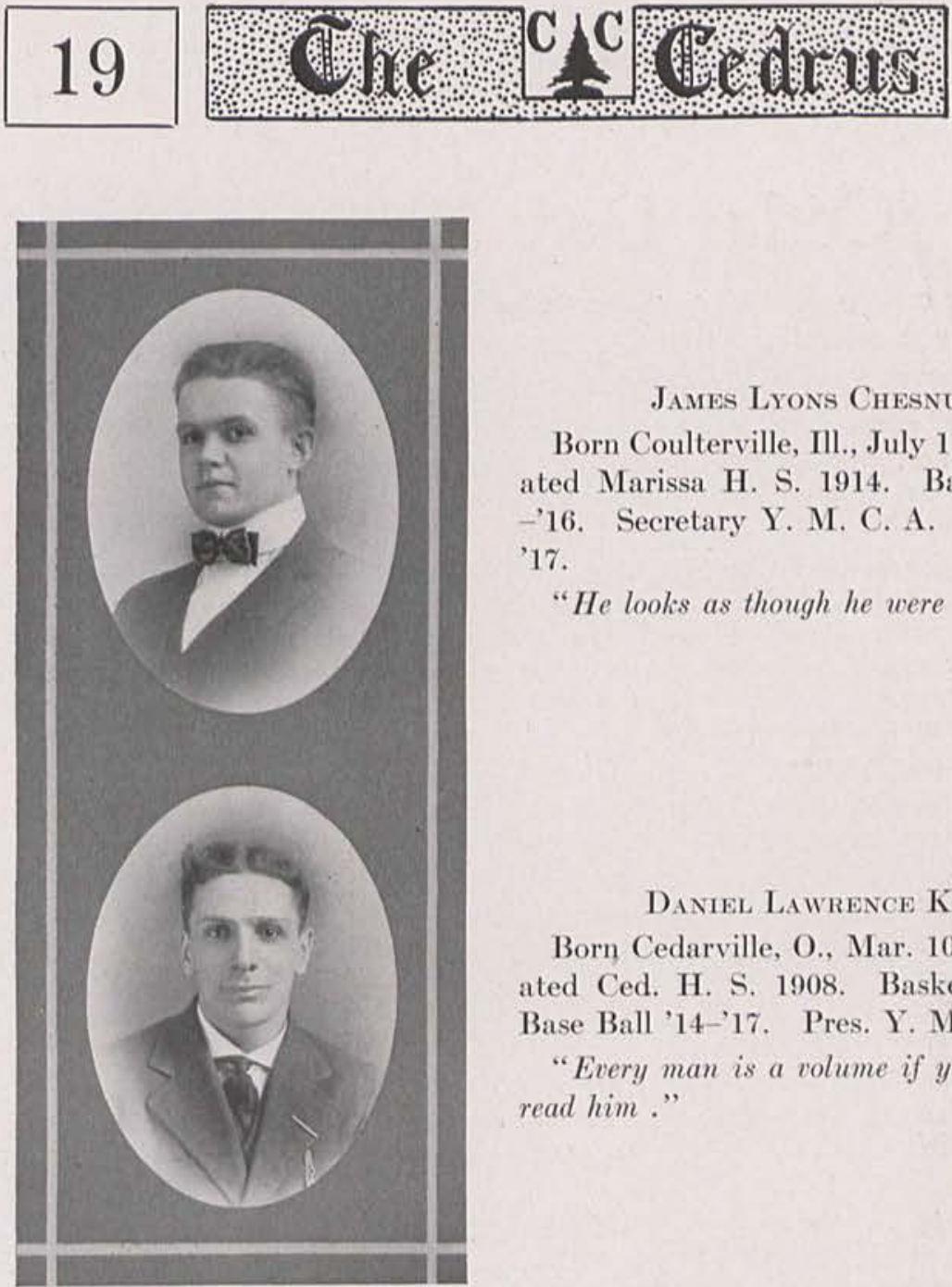

James Lyons Chesnut

Born Coulterville, Ill., July 11, 1897. Graduated Marissa H. S. 1914. Basket Ball 1915 -'16. Secretary Y. M. C. A. Base Ball '15'17.

"He looks as though he were in love."

Daniel Lawrence Kennon

Born Cedarville, O., Mar. 10, 1890. Graduated Ced. H. S. 1908. Basket Ball '14-17. Base Ball '14-'17. Pres. Y. M. C. A. 1916.

"Every man is a volume if you know how to read him ." 


\section{Cedar Day 1916}

$\mathrm{T}$

WE college campus decked in all its spring beauty, formed an ideal setting for the most delightful Cedar Day in the history of Cedarville College. Between seven and eight hundred interested spectators gathered around the arena to enjoy the stunts, May Pole Dance and Cedar Day Oration.

The program of class stunts was unusually original and pleasing. The Seniors presented two scenes from, "The Comic Supplement: The Captain Experiments with Baldine, and The Whole Blooming Family."

The Juniors dramatized a thrilling scene from "Lord Ullin's Daughter," which was followed by a still more thrilling scene from contemporaneous history, when the Sophomores pursued and captured Villa. Cowboys and girls on horse and pony, heavily armed, finally brought low the object of their pursuit. A well equipped Red Cross Ambulance manned with a corps of Red Cross nurses was on the scene to pick up the wounded and dying and carry them off the field.

"The Freshmen's Delight" was the last thing to be thot of in connection with our demure little Freshmen, for "The Delight" on this particular occasion was an old-fashioned square dance, which served however to delight the audience as well as the Freshmen.

The students in the music department gave an exhibition of musical ability and skill which we think even our efficient instructor in Music had never discovered. The "Orchestral Selections" were played upon instruments which were indeed fearfully and wonderfully made, many of which might have looked more at home in the Domestic Science department.

The ceremonies in Connection with the planting of the tree were in charge of the Sophomore class, and in honor of the Cedar Day Orator, Mr. James L. Chesnut Jr., member of their class, they chose to plant a chesnut tree instead of the evergreen.

The May Pole Dance was very beautiful as the girls in rainbow dresses and the boys in white attire danced in honor of the May Queen, Miss Dorothy Collins. The queen was lovely in her flowing robes of white, attended by her ladies in waiting and surrounded by her small pages.

After the festivities of the morning the delighted spectators enjoyed an abundant pienic dinner at the Alford Memorial. The college students had as their honor guests the Seniors from many of the neighboring High Schools and the members of the General Synod of the Reformed Presbyterian Church which was in session in the city at that time. Following the repast several friends of the college gave brief, interesting, after dinner speeches.

In the afternoon the college base-ball team met and defeated the Jamestown Athletics in a hard fought game, by the score of 7-2.

The entertainment presented by the Y. W. C. A. formed a fitting climax to the festivities of the day. With the assistance of some members of the Y. M. C. A., they presented a three act comedy "The Elopement of Ellen," and a splendid program of readings and music.

Cedar Day has a place in the heart and life of this community, which it can never lose if all Cedar Days are as successful as that of 1916. 


\section{9}
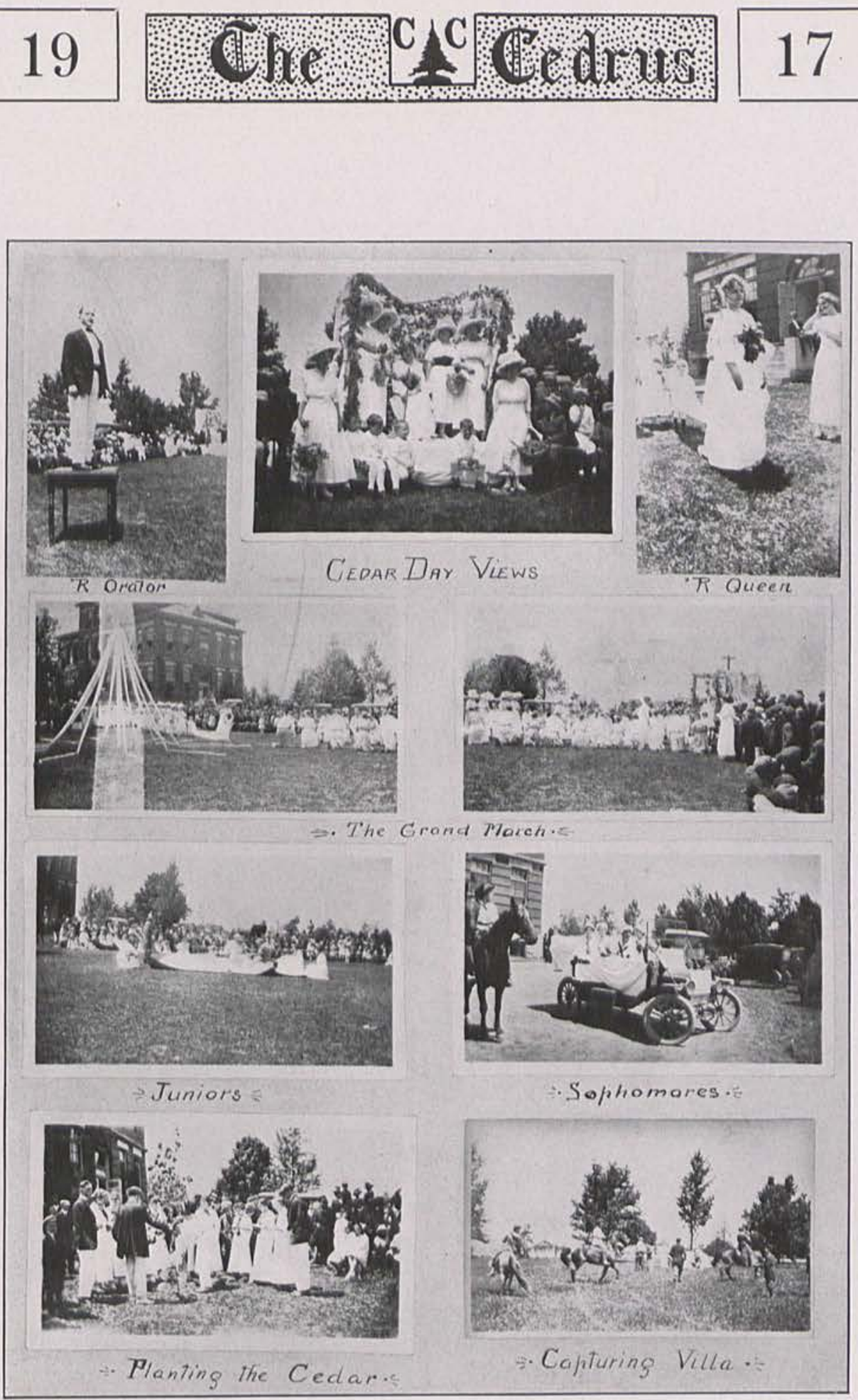


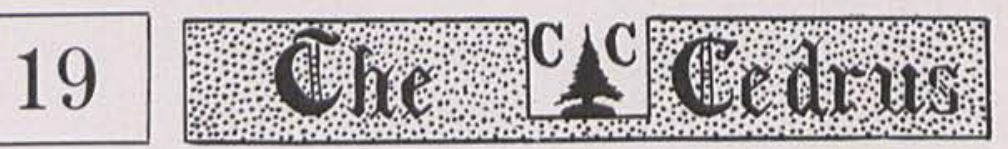

17

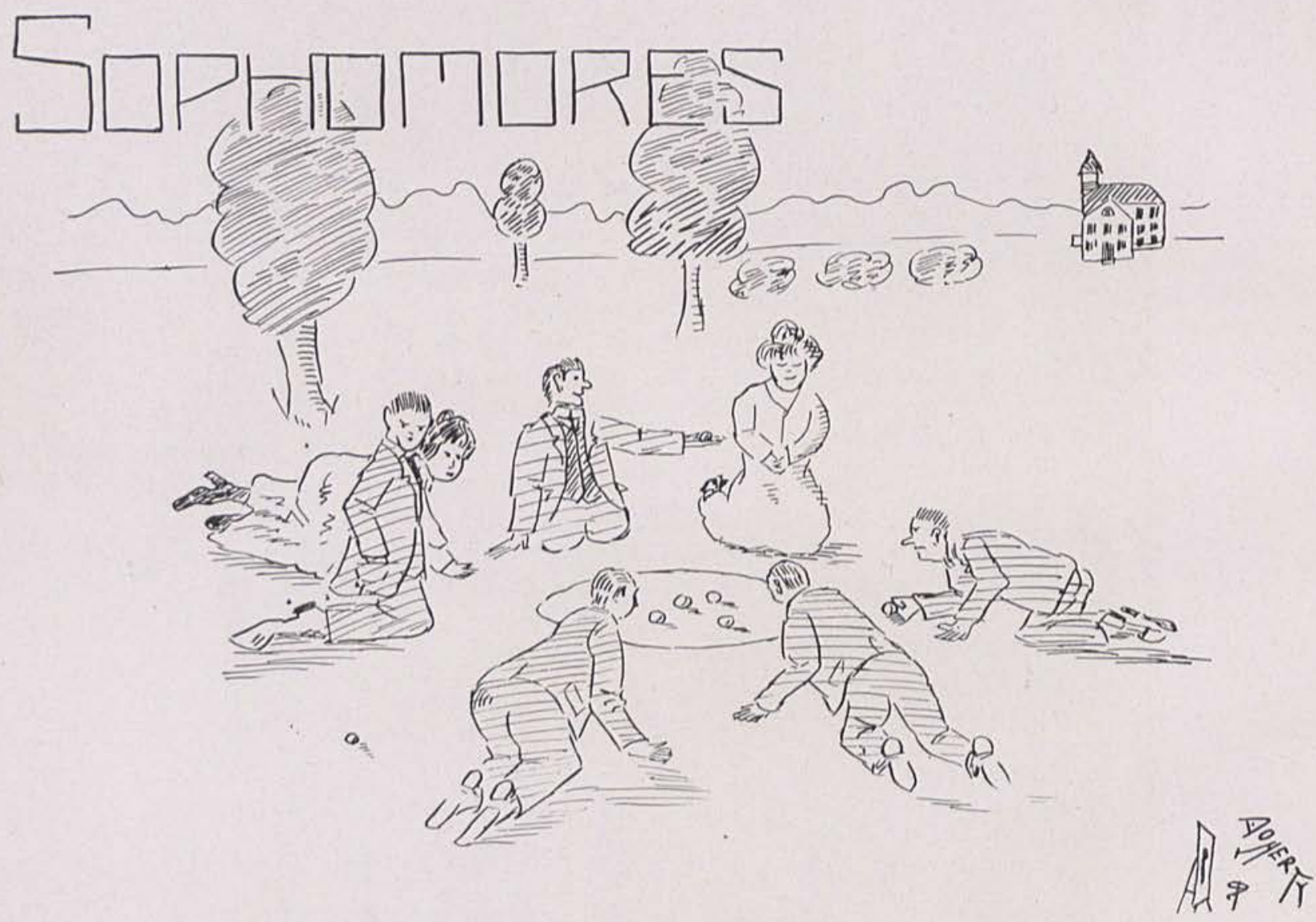




\section{9

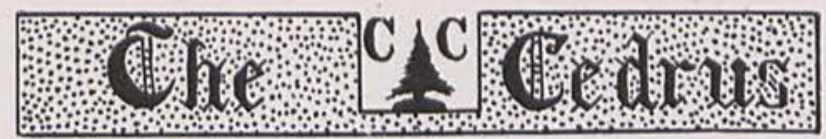 \\ 17}

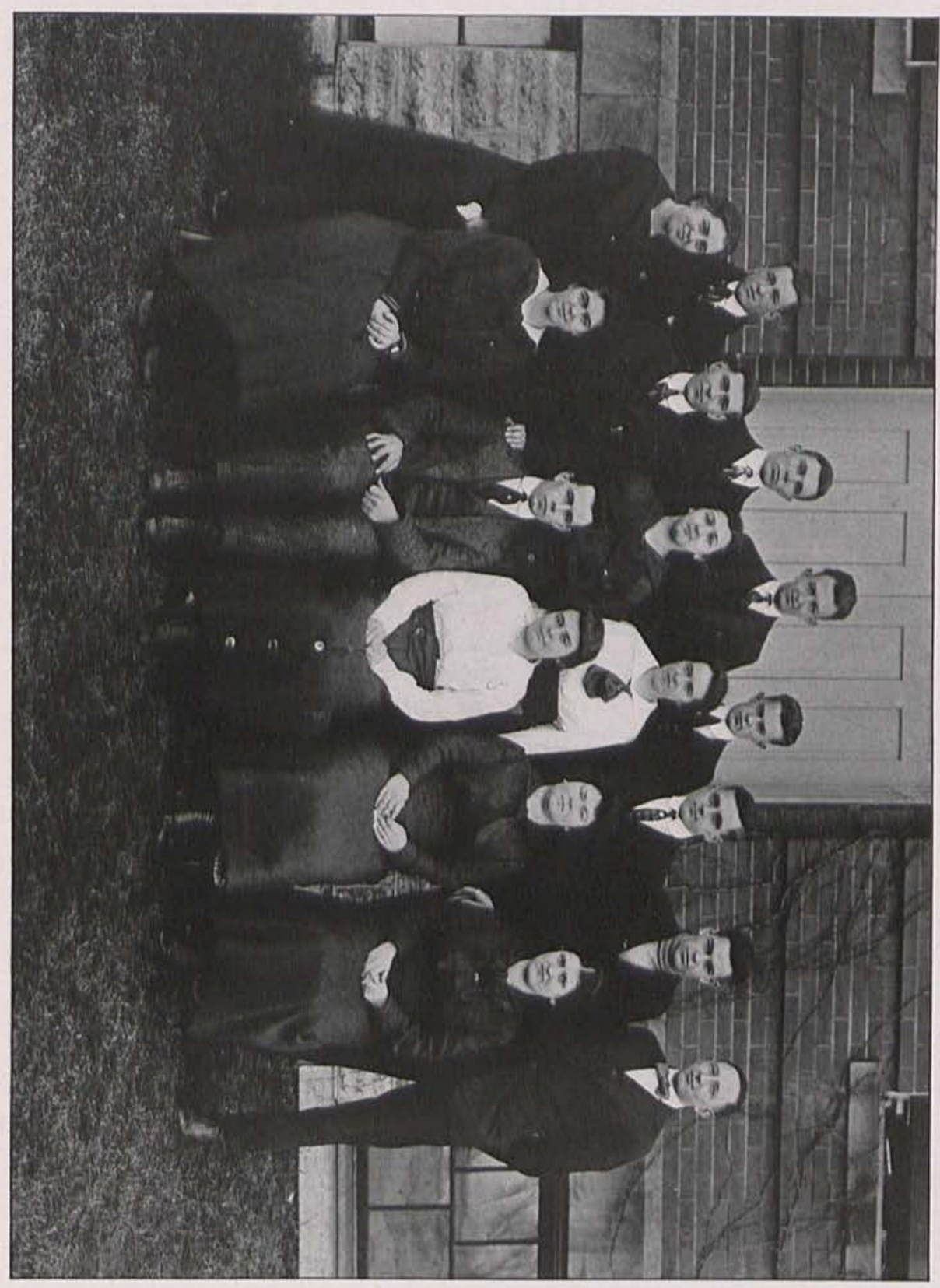




\section{9}

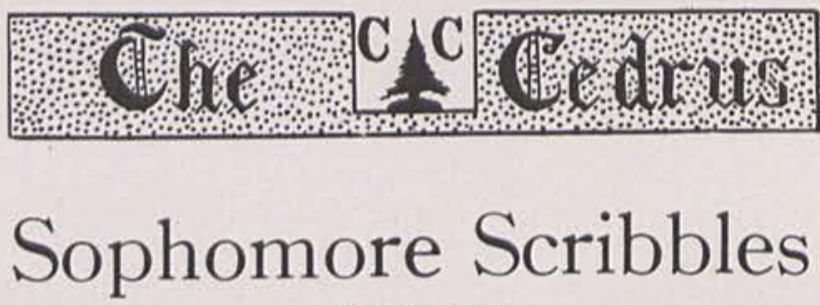

1916-17

\section{Sophomore Scribbles}

\section{$1916-17$}

$\mathrm{O}$

CTOBER - School today as usual. Evening came apace and "Old Sol" crawled under the covers of his woolly western bed, as if to say, "Now the day is done." He oughta stuck around, for he sure missed the fun, JuniorSenior spread was noised abroad. Having located the place of the spread at a Xenia avenue mansion, some of us climbed through a rear window and interrupted largish Senior and two elderly damsels cooking wieners. They slammed the dining room door in their retreat. Guess they thought it was the Kaiser!

We then withdrew to the front yard. Received a hot and cold water bath; also soft tomato for eye-brow shampoo.

Auto raid concluded the episode, and so to bed.

Successfully flunked in studies next day, much to the surprise of the Profs. NOVEMBER - All invited out for Thanksgiving. Some eats! Wasn't even a shadow of turkey left after we got through. Felt the effects for weeks afterwards.

DECEMBER - Scarlet fever scare! While at the home of one of our classmates enjoying one of our infrequent spreads, the joyful news came that the college was under quarantine for at least two weeks. Much telephoning to confirm the news. Then exclamations of joy and frantic huggings among all present.

JANUARY - Back again rested and refreshed. Nothing but hard grinding from this on, to make up for what we didn't do before the holidays.

As exams approach the Profs. wear a fierce aspect and the students a more worried look. Hope for the best! If we all pull through we'll celebrate with another spread.

FEBRUARY - We have all received our grades and have made out our schedules for another semester's work.

Had a fine lecture in chapel. The speaker hit everybody in the college but us. We did'nt need it.

Dr. McChesney had to lecture the Freshmen for breaking college rules. Why can't they follow in our foot-steps and keep out of trouble?

MARCH - Who said our class has lost its pep? Just because we are so industrious and always have our lessons so well prepared is no sign that we don't like a little fun.

We had another spread the other night. Some more eats! Say if you don't think our Sophomore girls can cook, you ought to come and see (that is, providing you were invited, for it wouldn't be healthy for you otherwise.)

What do you think? The editor said we had to cut this thing short, but I can scarcely quit until I present to you a poem selected from the Sophomore scrap-book entitled, 


\section{CONTRAST}

"I fear I'll do to much," the Freshie said;

"I'll more than earn my way;

$I$ don't intend to bust my hames,

Studyin' every live long day.

For such a stipend as I get

In this awful busy place

And if the Profs can make me sweat

They'll have a merry chase."

"The day is far too short," the Sophomore said,

"For all I wish to do

The hours fly past and day light's gone

Before I'm half way through

And tho' my way looks pretty slick

I'll work like old Sam Hill

Till Prof. observes that I'm a brick

And can do what e'er I will.

You see the Profs were keeping tab

As professors always do

To Freshie said, "Young lad look here!

We have no use for you.

The lad who fears he'll do too much

With tramps will roam the pike

And when he's old, he'll be in touch

With poor farms and the like."

To Soph' he said, "Tve marked your gait

Since first you came last year

And early you have toiled and late

Naught but your praise $I$ hear.

For all the time and every day

Such lads Professors seek;

And I will now increase your grades

By fifty points each week." 
19

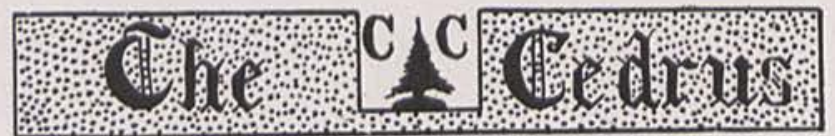

17

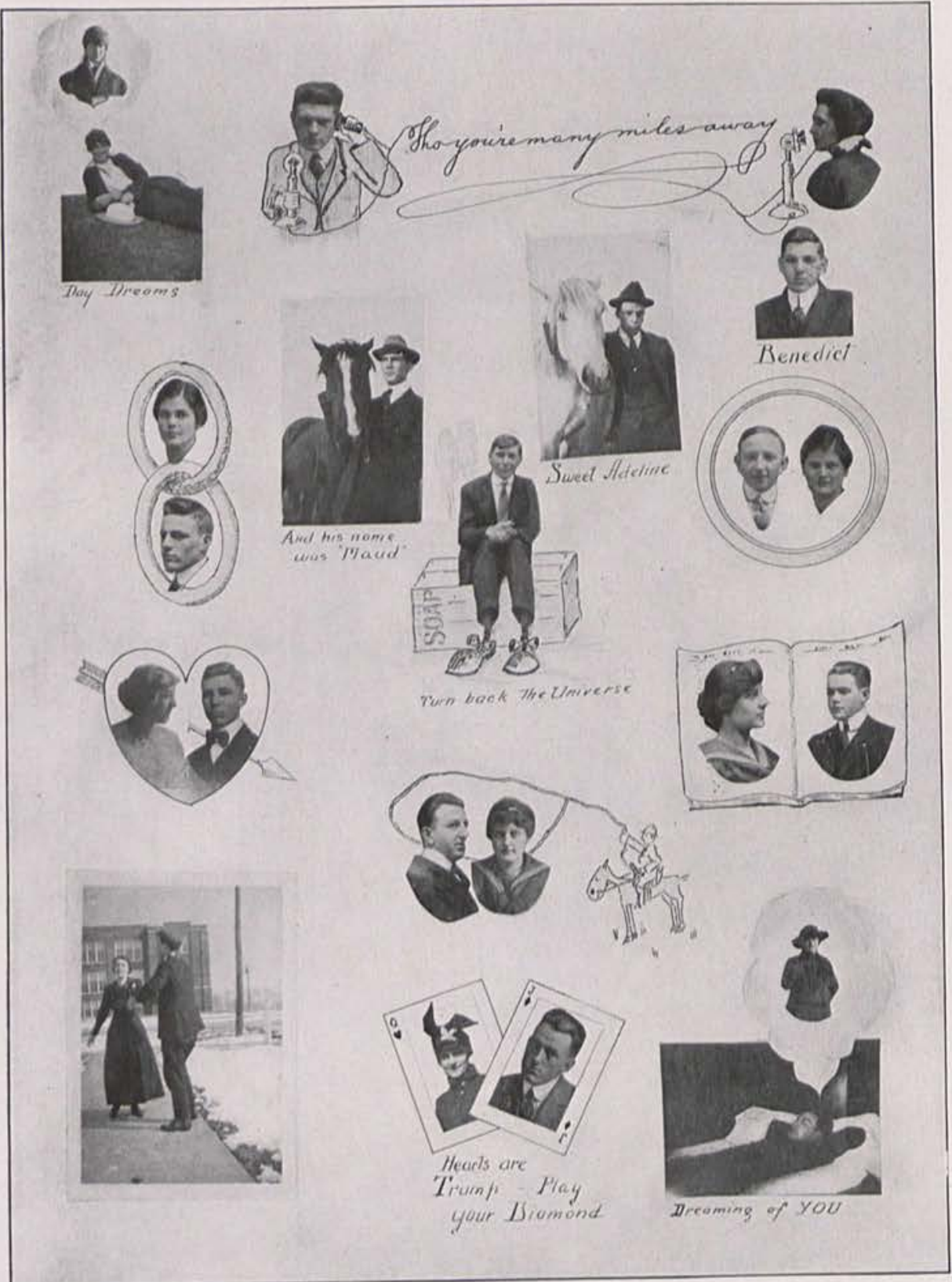




\section{9}
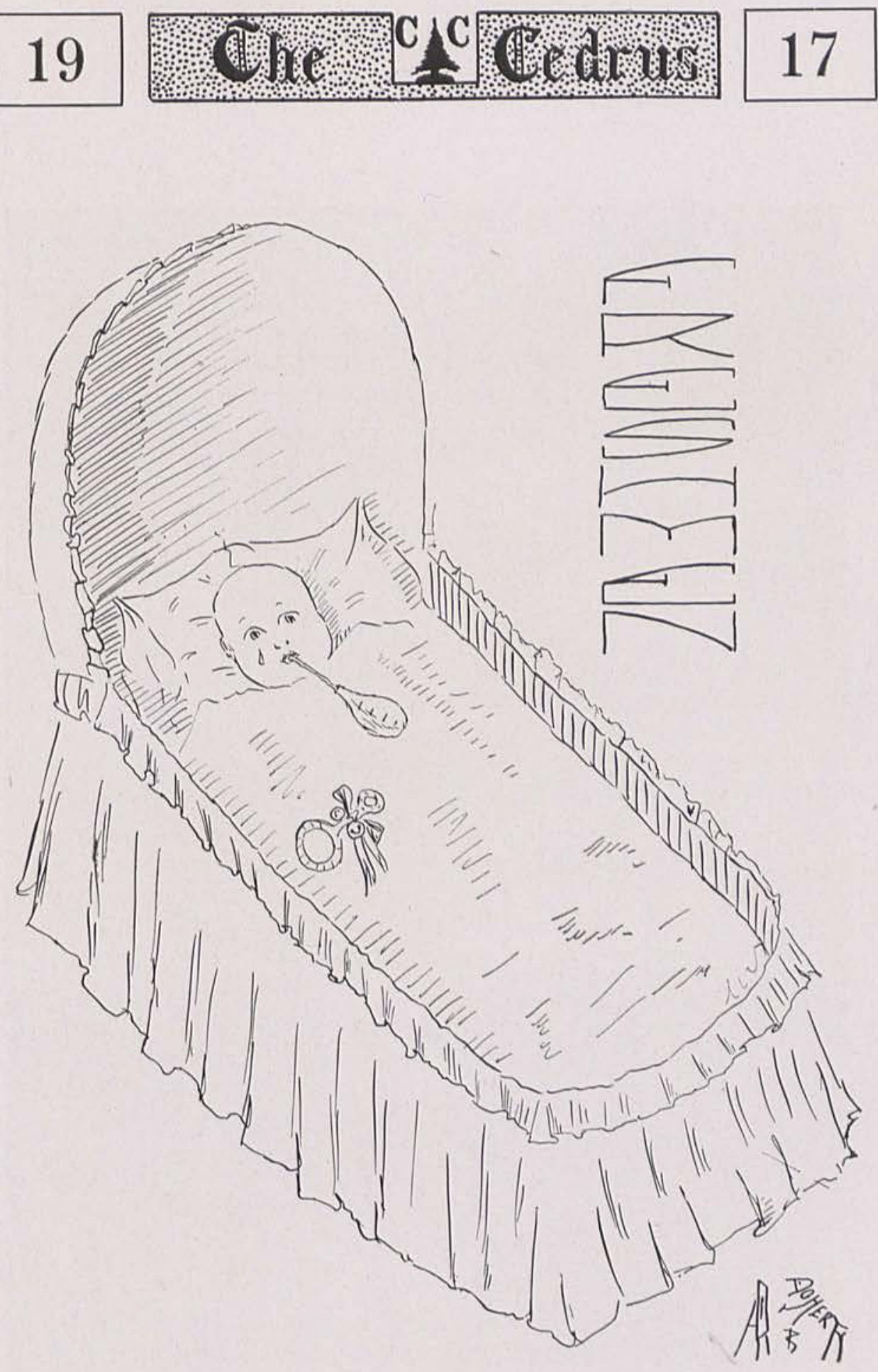


\section{9}
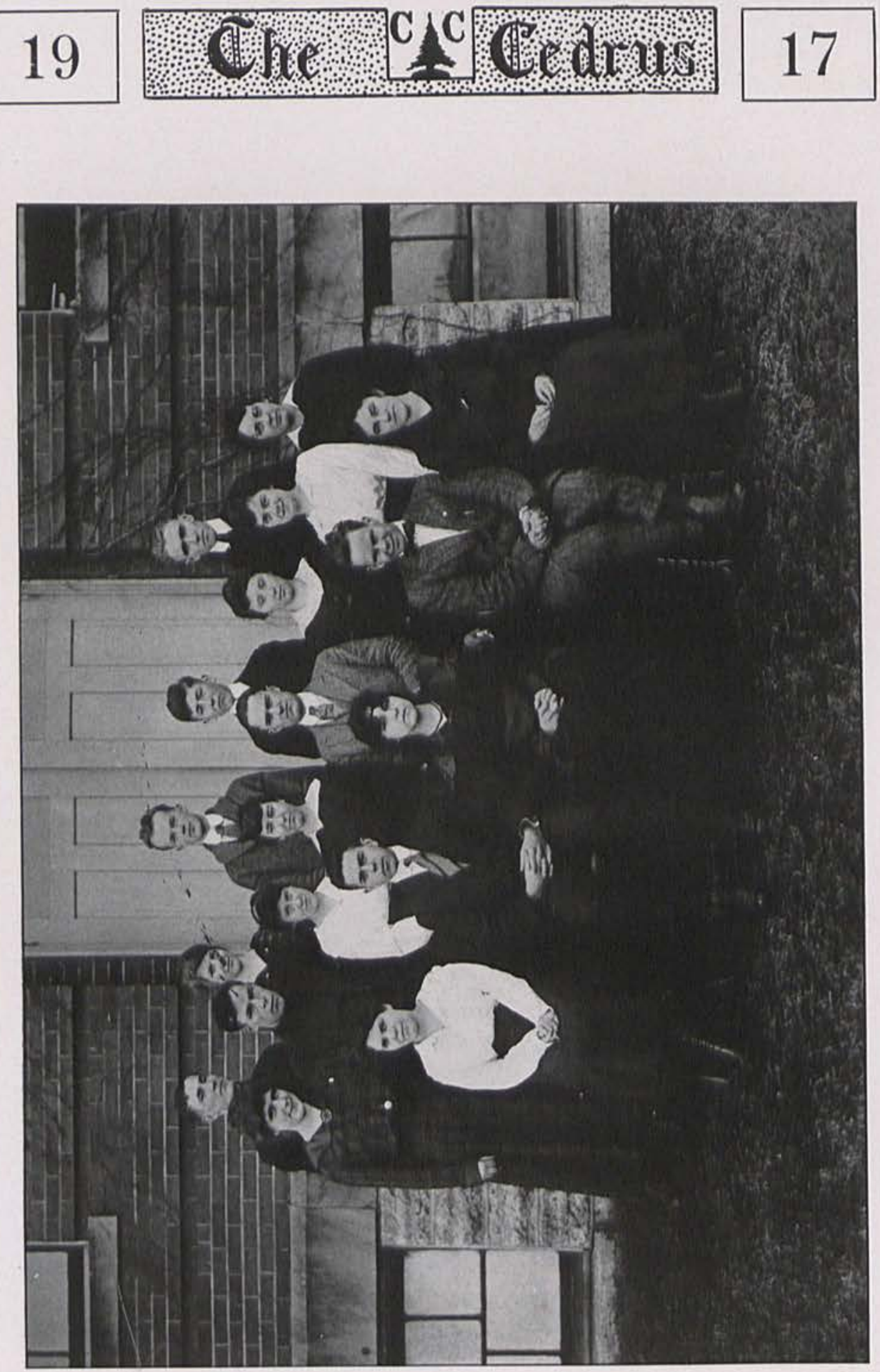


\section{9}

\section{Freshman Class History}

$\mathrm{W}$

E, the Freshman class, ever since September have lived the modest and secluded lives that all truly great people live, but the other classes have now become so loud in their praises of us that we feel we would be doing the College an injustice to remain quiet any longer.

Of course, you will not think for one minute that we are boasting, when we tell you that four of our boys are members of the second basket ball team. Furthermore, we feel that it was the second team that enabled the first team to be prepared to win the Antioch game as well as many other games this season. Oh, of course we are very proud of our boys, but far be it from us to boast about it. We'll let others do that. Also three of our girls played on the girls' team. They were some players, too! In fact they - but there! We positively will not blow our own horn!

Our class is undoubtedly the best and most congenial class in school. At least the other classes must think so, for they usually try to "join" us when we have a spread or when they "think" we are going to have one. Say, when it comes to "Spreads" the Freshies cannot be surpassed, not even by the Sophomores.

One more worthy thing of mention is that several of the most brilliant students in college are members of our class, but in our modesty and humility, we did not dream of such a thing until the faculty informed us. However we were not surprised (being naturally bright.)

We are sixteen in number, yes sweet sixteen, and each member will always be loyal and true to the scarlet and black, for we love our class and the college of which it forms a part.

Ah. distinctly I remember it was in the fair September

When each fresh and green young member cast a shadow on the door!

Eagerly they came to college, eagerly they sought for knowledge,

From east and west and north and south the students all did pour.

E'en the rare and radiant Louisa - all who knew her did adore

Even then and-evermore.

And the glorious, glad uncertain Ellen, giggling more than working,

Thrilled all-filled Morton with fantastic terrors never known before,

And another one named Horton, shared the same fate then as Morton,

And thots and dreams of love into his beating heart did pour-

All inspired by one named-Millie - she it was and no one more,

Same old story - evermore.
Presently then bye and bye came Reba Harbison sweet and shy,

Helen Bradfute stately and pretty and Deane with knowledge in store.

And the fact is, next came Duncan, always passing never flunkin,

And Anderson with loyal heart making friends there by the score,

$\mathrm{Oh}$, they'll never be forgotten - tho their absence we deplore,

All of them-forevermore.

Clark was next who came to town, followed by Elwood the college clown,

Then there came jolly Rebecca our friendship to implore,

Dorothy Smithson charming and rare was another who entered there,

Lastly came Polly who tho loyal to the core, was rather fond of a Sophomore,

But all thru the annuals of the past we find the same old story o'er and o'er,

And thus 'twill be forevernore.

(With sincere apologies to Poe.) M. G. 


\section{The Summer School}

$\mathrm{H}^{\prime}$

ISTORIANS tell us that there were two French Revolutions: the first one peaceful, which turned France from an absolute monarchy into a limited monarchy: the second one violent, which overturned the monarchy and established a republic.

No greater contrast can be imagined than that between the Summer School of 1915 and that of 1916 . In 1915, there was tumult every night; whether chicken roasts, marshmallow roasts, receptions, parties, watermelon rollings, spreads, or picnics. Every evening after supper about a hundred of them could be seen down at the station waiting for the $6: 20$ and the $6: 49$. In 1916, not a soul was to be seen there but Neff, parading the macadam in solitary grandeur. The rest were studying.

But Neff had his lessons just the same. Perhaps he was looking, in vain as it resulted, that some of the 1915 paraders would loom up before him.

Instead of them we had Eckelberry the sociologist: Dunn the mathematician: Sayre the "scrap" expert: Hill, the big man: and McCall, who handed in his, work typewritten. Billings and Miss Lunn and Day revived the glories of former days, while Burns turned from teacher to student and did a year's work of French in six weeks. Time would fail to tell of the others, but you can get their names out of the catalog, and a catalog can be got at the price of a postcard.

But what we started to say was that the squad was as quiet as the 1915 crowd was stirring. They worked like demons. It was a new experience for some of the teachers to have a class take an assignment, no matter how long, without a murmur; and come up the next day prepared to recite the last topic just as well as the first. And the summer was hot, the hottest one in forty-six years. We hope that it will be forty-six years before we have another one like it. Maybe Hughes's campain* speeches had something to do with it.

*"Campain" is simplified spelling for "campaign." 

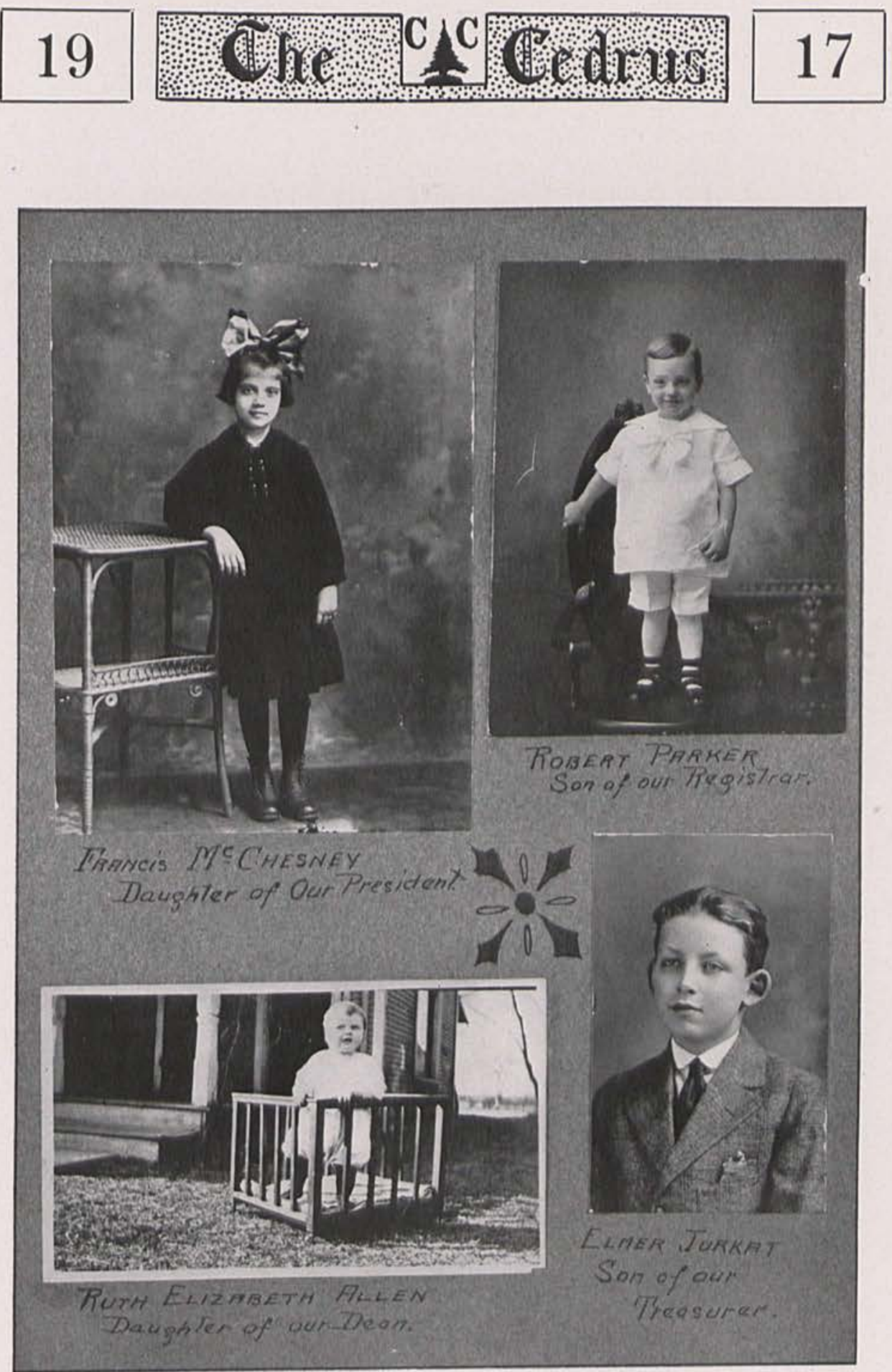


\section{9}

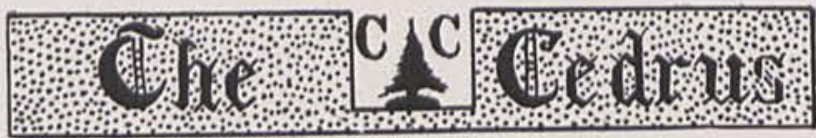

\section{Time: Seven Minutes}

$\mathrm{T}$

HE sharp jingle of the telephone is startling in the dead of night when there is no other sound. John Mason awoke from his sleep with a start. His hand shook as he took down the receiver.

"Hello!"

"Hello! Is this Mr. Mason the cashier?"

"Yes, Who is this?

"Not so fast, please. My business with you is strictly private. Are you alone in the room?"

Coming to him as it did, the question seemed a bit uncanny.

"I am," he answered, glancing around a bit apprehensively as tho' he did not feel quite sure about it.

"Well, this is from the bank. Understand?

"I do not understand. The bank closed at four o'clock; I locked the door myself and no one else has a key. Who are you anyway?"

"Ah! softly please. Don't be inquisitive."

"Then what do you want?"

"Now you-are-talking. First, though, let me tell you something. You know that powder you have stored in this basement ready for the hunting season?"

"Well, what of it?"

"Make quite an explosion wouldn't it?"

"It would wreck that whole building."

"Yes, Well, just at this moment one end of a good fuse rests in that powder and the other end is on your desk within three feet of my hand. Do you see? Hello! Hold on now; don't get excited; a fuse doesn't hurt as long as it isn't lighted. Just wanted you to see what might happen if things didn't please the people in control here, that's all. Still I have something more to say to you. We have a little work here that requires the opening of this safe. Hello! are you still there? Alright. We seem not to have got the combination, and prefer to call in the engineer rather than blow up the boiler. I'm sorry to disturb you, but we have tried to be as considerate as possible. You'll find a cab at your side door. By smart driving you can get here in six or seven minutes from the time you leave the phone; but, mind, that will not give you time for any trips to a police station or any other nonsense. If you are with us in exactly seven minutes from the time you leave the 'phone well and good, if not-hello! are you still listening?"

John Mason promptly answered that he was listening, tho' he did not feel quite sure whether he was hearing with his ear or his imagination.

The situation was a new one to him and in order to gain time for thinking it over, he tried to talk with his strange interviewer with one side of his head and think with the other. The warning was prompt.

"Cut it out! Are you there? For if you aren't the fuse is off. 


\section{9}

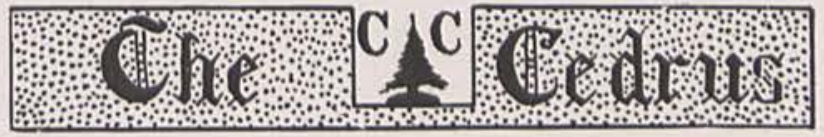

"All right! I'll come!" he shouted and hung up the receiver.

What could he do to arouse his house-hold and the servants without taking nearly all of his seven minutes?

While in the act of doing so, a cab pulled up. He got in and was whirled to the bank.

A glance around showed Mason that the bank was still unwrecked, so it looked as tho' he had arrived on time.

Being afraid to enter, Mason tho't it best to wait outside, Neither burglar nor explosion came to reward his caution, however, and curiosity getting the better of him, he telephoned the police, and upon their arrival, after explaining to them that he was the one who sent in the call, they all entered the room.

In the center of the room lay the door of the safe where it had fallen when blown open. The money and valuables were missing. Evidently it had been a deliberate job, where every paper was examined and its value carefully determined.

"And only to think," exclaimed Mason, "that they did it all in the few minutes I was coming from my house here! I'm certain they were gone before I arrived."

"Nonsense," said the chief. "My opinion is that the safe was blown and the job done when they called you. They were off as rapidly as you were, after they once got you started. Strange though, that they went to the trouble of sending that cab for you if they hadn't some other object."

Just then the telephone rang again with a suddenness that gave them all a start.

"Hello! Who is this?" answered Mason.

"Is this Mr. Mason's bank?"

"It is. What's wanted?"

"Well this is your residence. I just wanted to tell you that we had a little business here which we tho't could be done better in your absence. We wanted you to take a little trip and felt sure you would manage to take the police along with you. We are all three here now and have managed not to disturb your family in the least. You and the police may return when you are ready. Thanks, good-bye."

John Mason and the officers looked at each other in blank astonishment for a full minute, then the chief exclaimed;

"Well, that was a slick job!"

"It certainly was," replied the crestfallen John Mason as he turned out the lights and walked thru' the door.

REBECCA MARSH '20. 


\section{9}

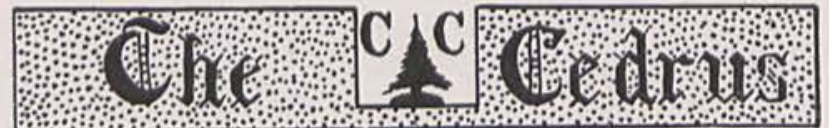

17

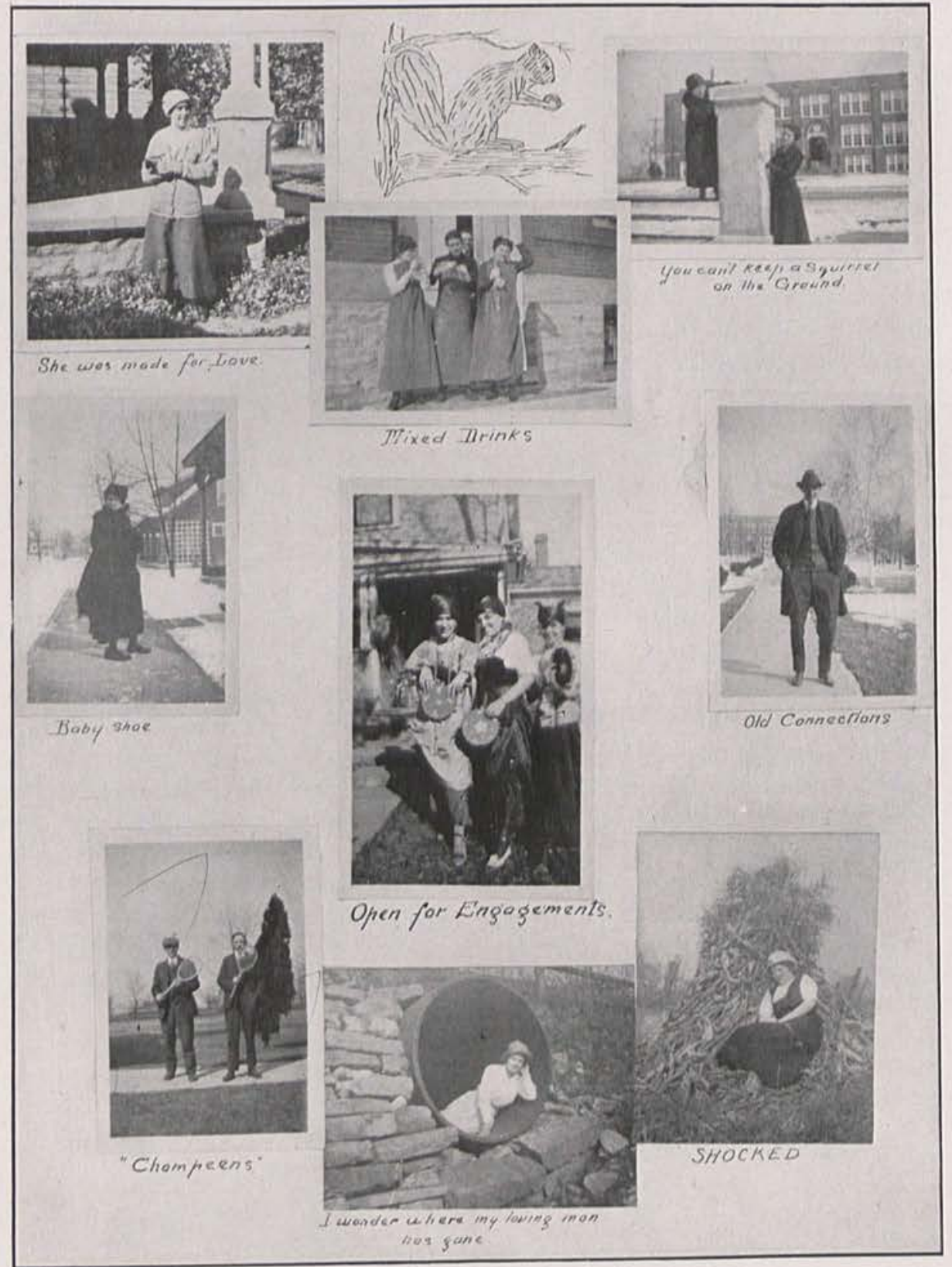




\section{9}

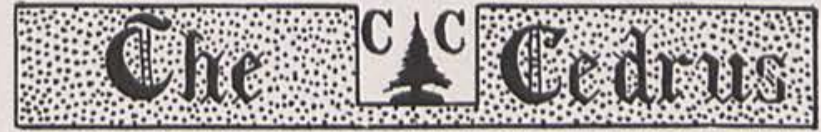

17

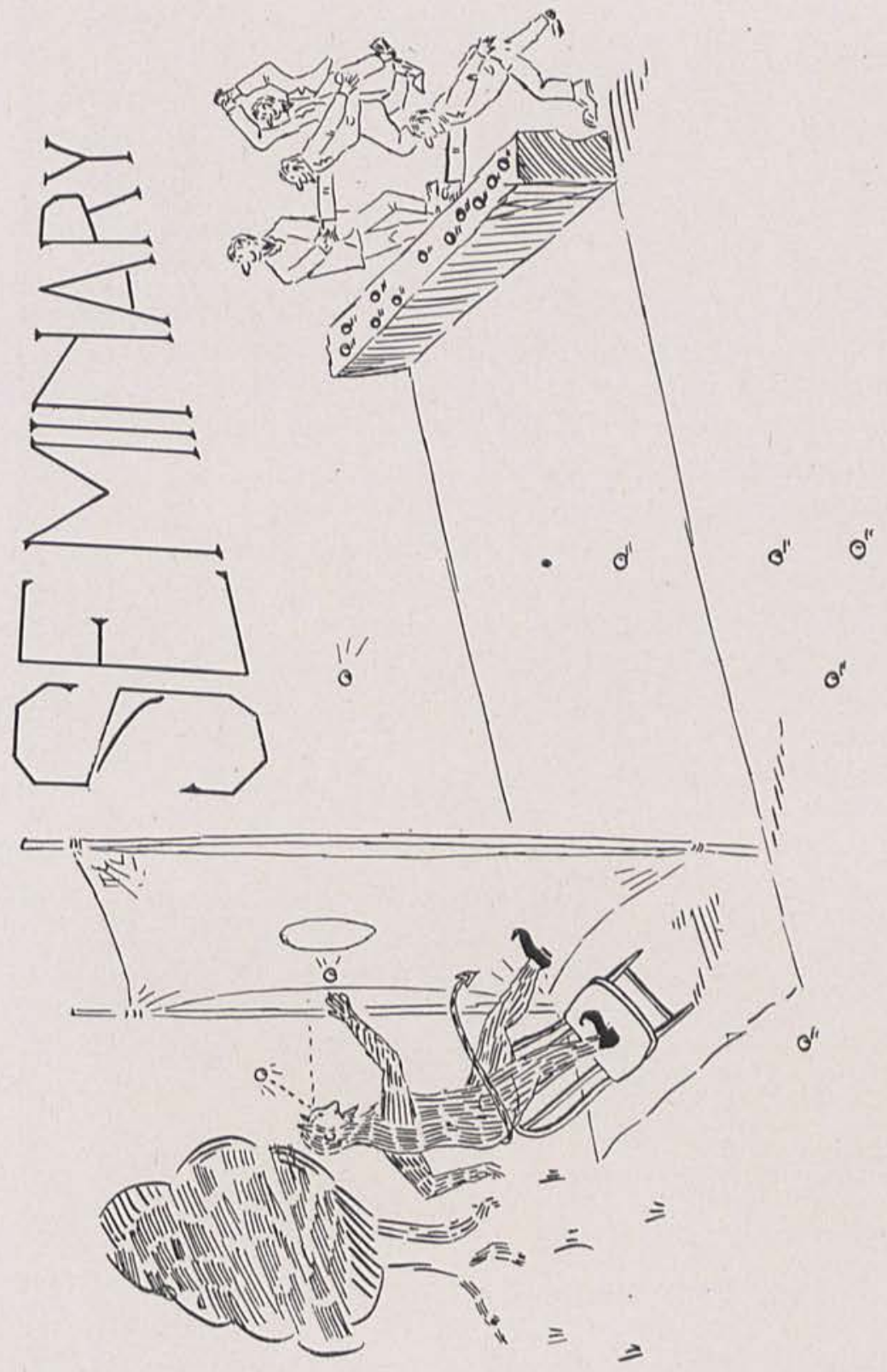




\section{9}
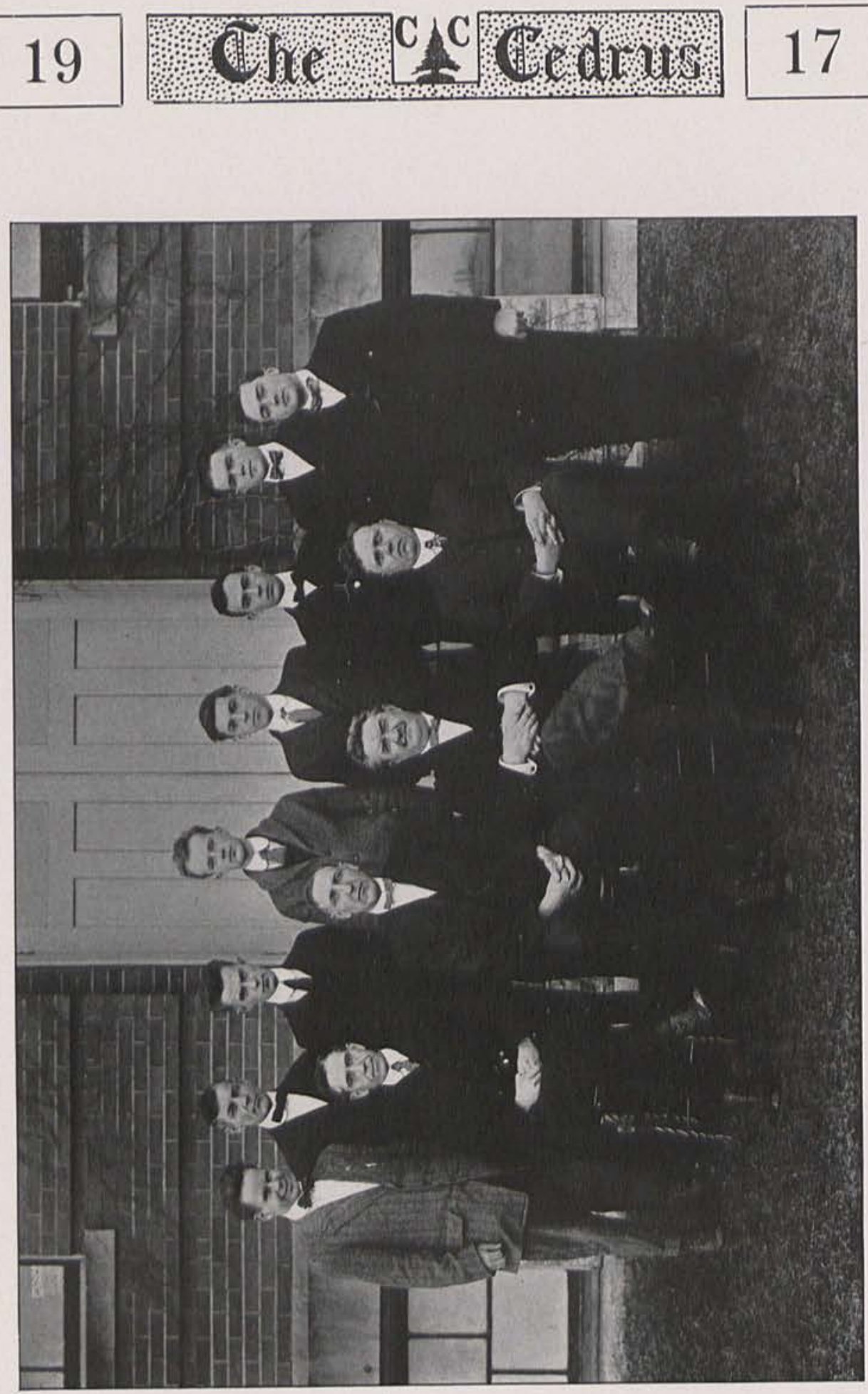


\section{College Life}

In September, we assembled,

An earnest and studious band,

For another year at dear Cedarville

The very best school in the land,

As Freshmen and as Sophomores, As Juniors and Seniors, too,

Tho' we came with various plans

And preparations for life in view;

Yet each one has striven to be

Unselfish and kind and true.

Old friendships have been strengthened

While others were formed anew.

$\mathrm{Oh}$, let us endeavor to finish

This year as we have begun;

And always to think of the other

Whether at work or in fun.

Let us cheer for President McChesney

And for the faculty, one and all;

Then let us go onward and upward

Ever ready for duty's call.

MARGUERITE GILKEY.

\section{"Cedarville's a College"}

Cedarville's a college in a grand old State,

Builed by the hands of a Ruling Fate,

Guiding earger students through the open gate

Of dear old Cedarville,

Fitting them for champions of the truth and right,

Arming them completely for the coming fight,

Leading them to victory over wrong and might,

At dear old Cedarville.

Chorus:-

Senior, Freshman, Soph., and Junior, too,

Join your hearts and efforts, and in everything you do,

"Onward! Upward!" be your motto still,

Follow close the leading of your dear old Cedarville.

Cedarville's a college full of joy and song,

Work combined with pleasure through the whole day long,

Happiness and gladness e'er to her belong.

To dear old Cedarville

Harmony and unity do there prevail,

Bitter strife and enmity shall ne'er assail,

In all that's great and glorious, she cannot fail,

Not dear old Cedarville.

Chorus:-

Cedarville's a college that shall ever stand,

Shedding light and glory over all the land, Reaching out to everyone a helping hand,

From dear old Cedarville.

Many be the victories that are in her way,

Many be the triumphs of the coming day,

Many be the students who shall always say,

"Our dear old Cedarville!"

Chorus:- 


\section{9}
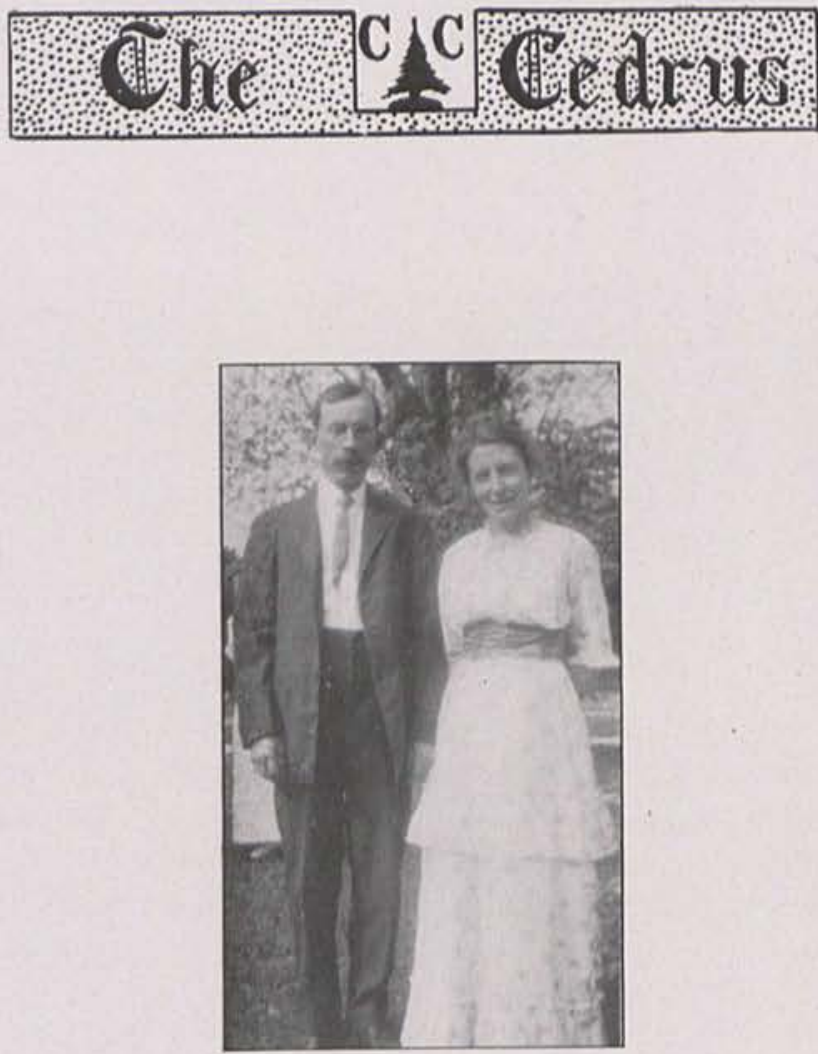

Mr. and Mrs. Stewart Townsley

We can live without art, We can live without books, But where is the man

That can live without cooks.

E do not feel that this annual would be complete without paying in its pages a tribute to Mrs. Stewart Townsley, who has kept the club for the last six years. It is with regret that the college students learned that Mrs. Townsley will not keep the club after this year, but the memory of her unfailing kindness, with which she received all who came into her home, will not fade from their minds. Mrs. Townsley is a splendid cook but that is not the best part. The cheer and sunshine which she served with the meals made even "blue Monday" assume a rosy hue. We feel that altho' she will not be so intimately connected with the college life after this year, that still she will be interested in the students and they can still claim some of the love and sympathy which she has shown for them heretofore. 


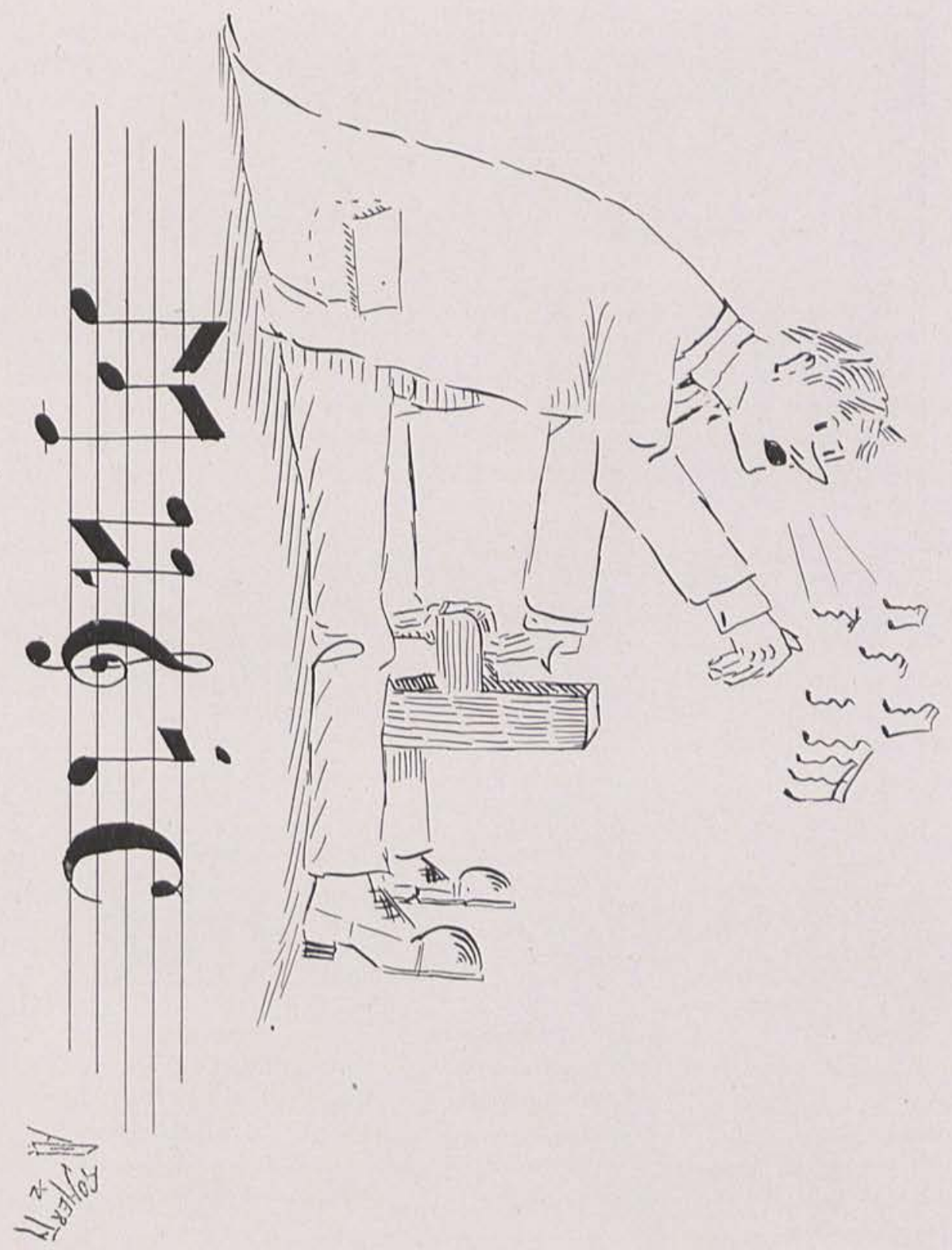




\section{9}

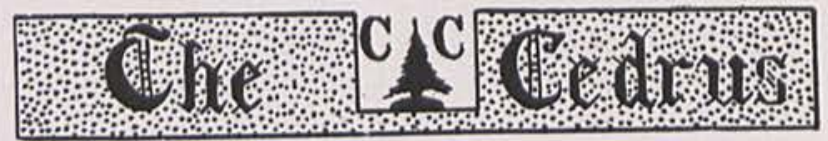

17

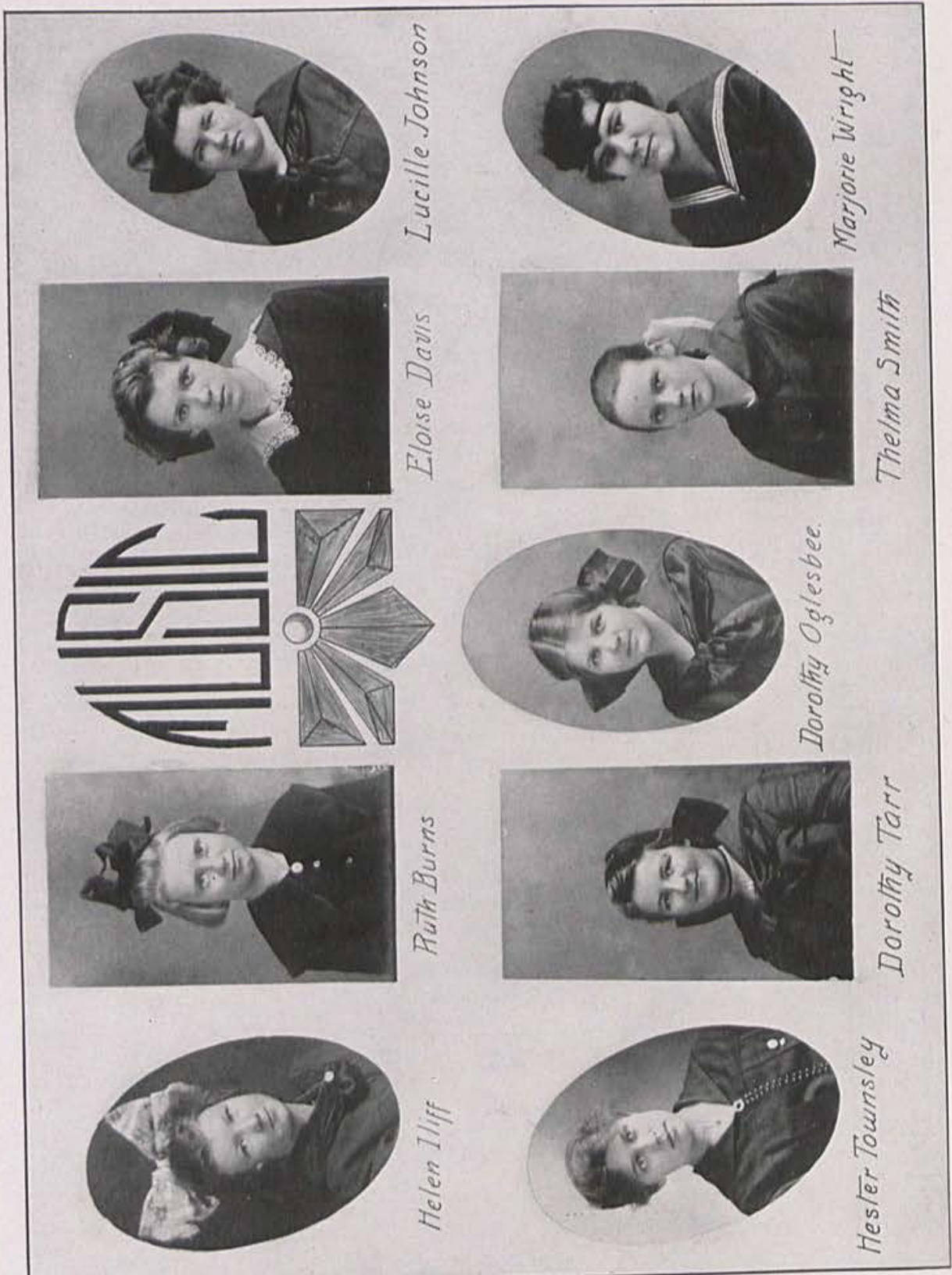



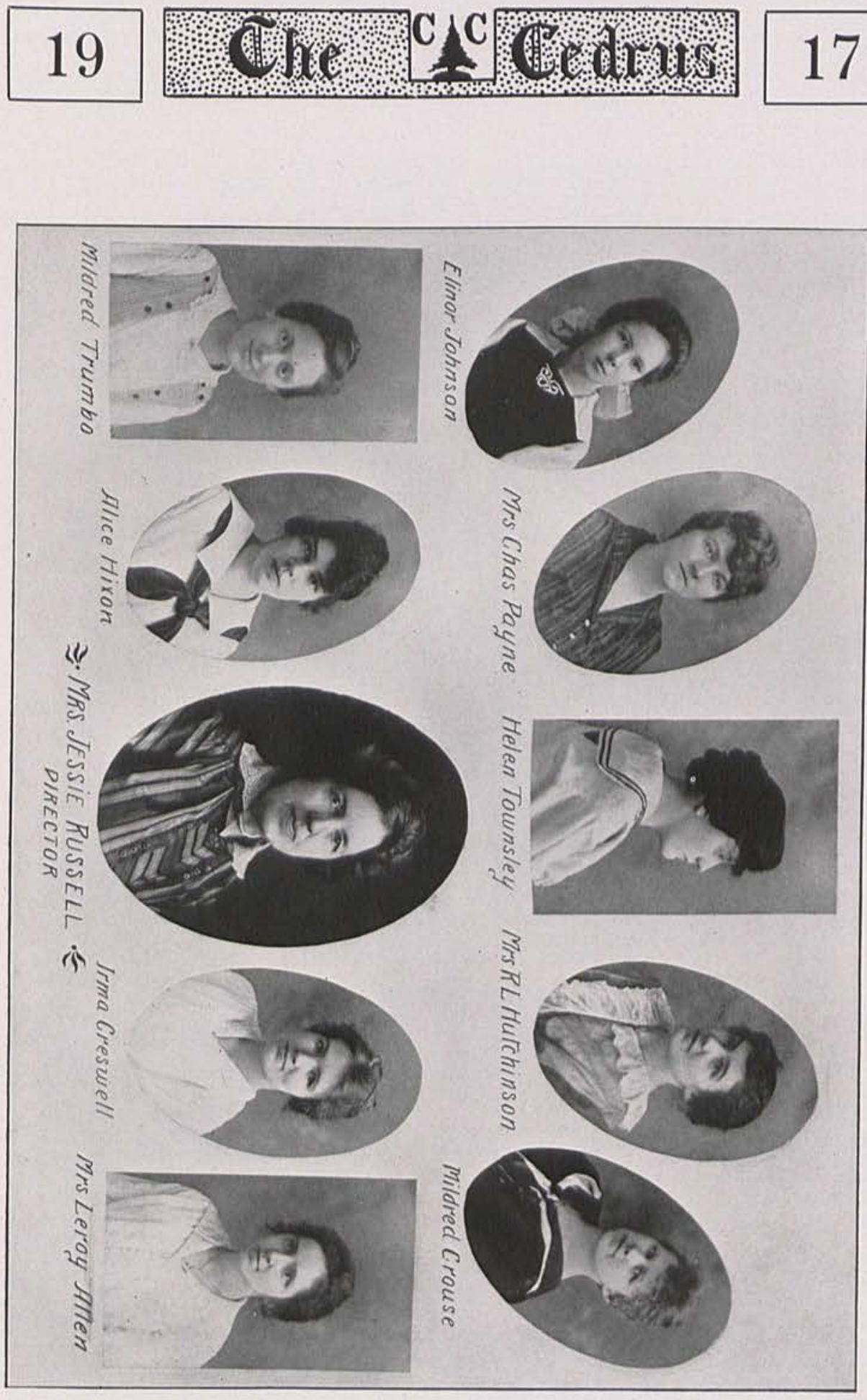


\section{9}
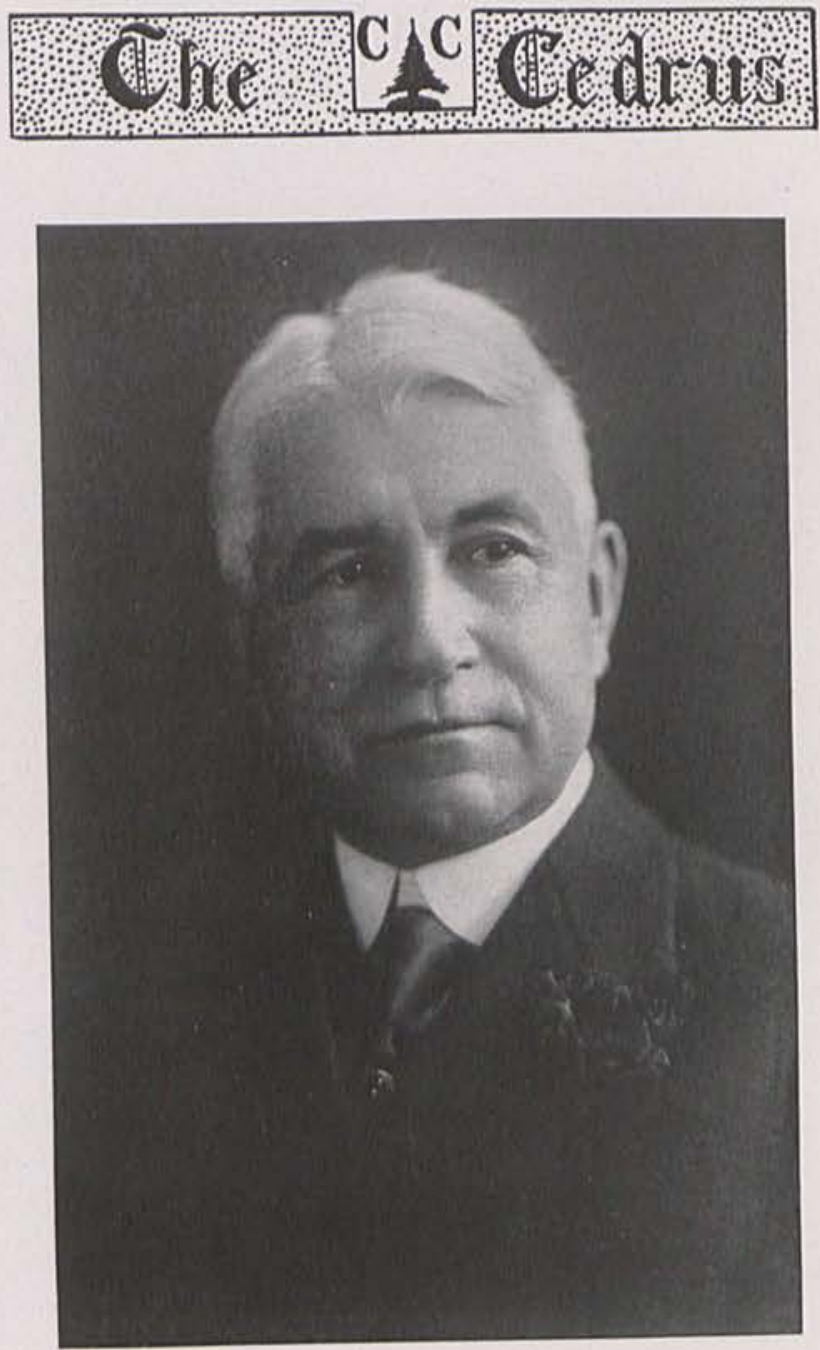

\section{Alford Memorial Gymnasium}

LFORD MEMORIAL GYMNASIUM was presented to our college in 1902 by Mr. W. J. Alford, as a memorial to his parents, Rev. and Mrs. John Alford.

As everyone knows, "All work and no play makes Jack a dull boy." Perhaps that is what the donor of our gymnasium thot when he presented it to the college. We have truly appreciated his gift. Many a time have the walls of the old gymnasium rung with the laughter and shouts of the students as they forgot for a few hours the cares of the class-room. The athletic victories that have been won on its floor have enabled us to win intellectual victories elsewhere; and even our defeats have not been total losses, for they have enabled us to gain self-control and show a game spirit, even when our plans were not always crowned with success. 


\section{9}
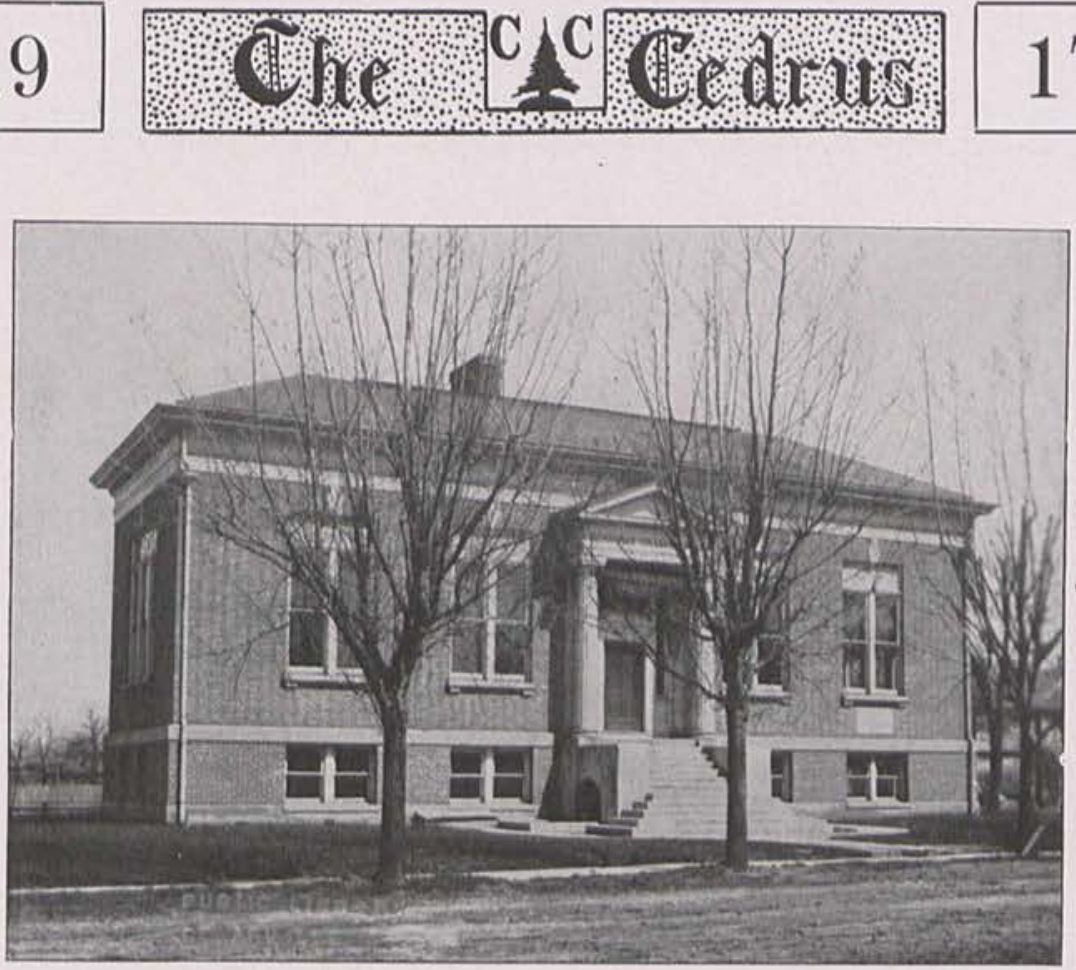

CEDARVILLE COLLEGE LIBRARY

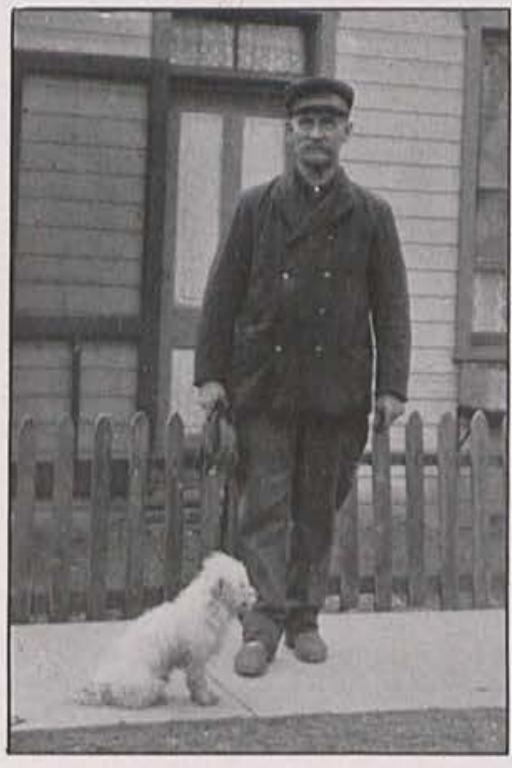

MR. GRINDLE

\section{Our Janitor}

There is not much one need say of a man like this, for his actions speak for him. But we feel that our Cedrus would not be complete without telling you something of the man.

His is the happy possession of a big heart and a great good nature. $\mathrm{He}$ is a man always cheerful at his work, no matter whether the day be bright or cloudy

It is Mr. Grindle that on cold winter mornings fires the furnace to keep our intellectuality from freezing. It is Mr. Grindle who does all of our college housekeeping. There never was a spread at the college, when Mr. Grindle was not there, doing all he could to help the boys and girls have a good time. $\mathrm{He}$ is a friend of every college student, always helping us out of difficulties.

In fact we feel that the college work could not move along so smoothly without the assistance of $\mathrm{Mr}$. Grindle. 


\section{9}
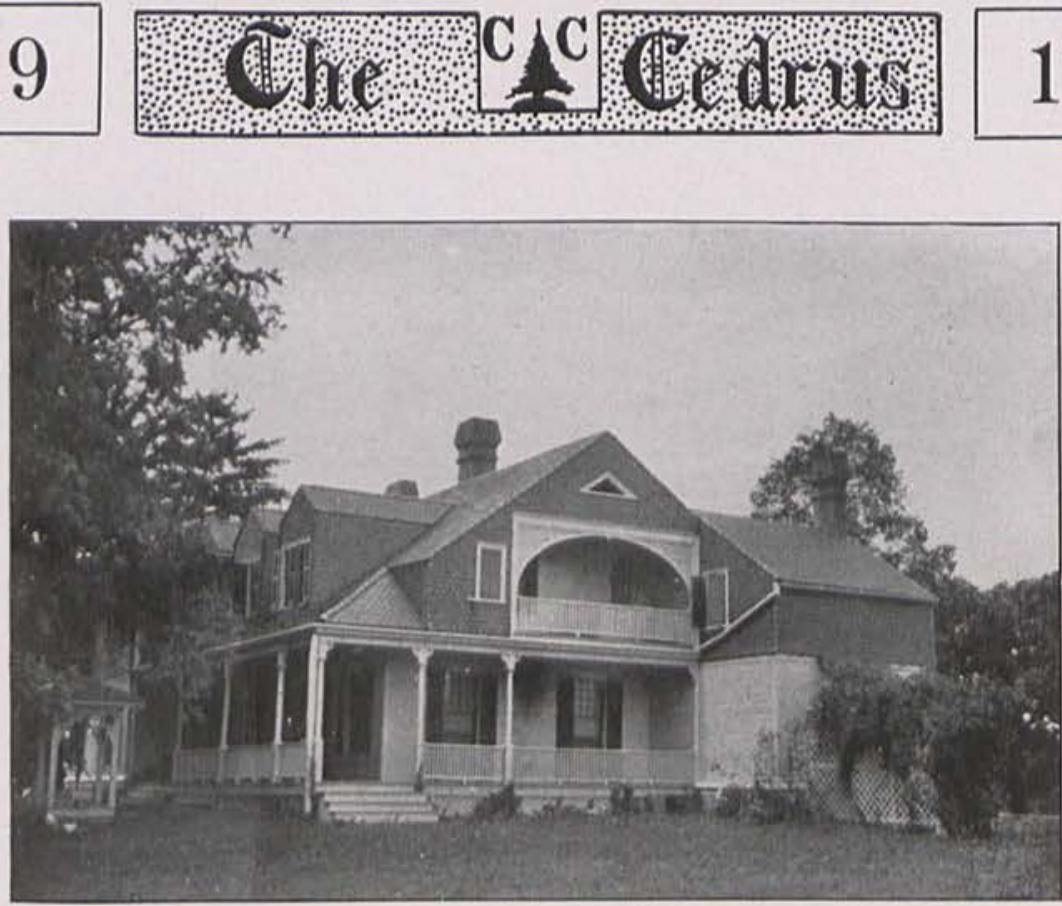

WHITELAW REID HOMESTEAD

\section{Life of Whitelaw Reid}

$\mathrm{W}$

HITELAW REID was born, October, 1837, at what is now known as the Reid Homestead, two miles west of Cedarville. He was a very delicate child but possessed unusual intellectual ability. He was a great lover of books and before he was ten years old was a voracious reader. He was thorough in all that he did and at the age of fifteen entered college a better scholar than his higher classmen. He graduated from college in 1856. His commencement oration was beautiful, his rhetoric and style were classical. He stepped out into the world ready for life's battles, with a noble ambition and will power, that made him a winner in every position of life which he occupied.

He became a teacher, reporter, army correspondent, congressional librarian, editor of New York tribune, candidate for vice president, representative of United States to coronation of King Edward, minister to France and United States embassador to England. He served many years at the latter place.

He died in London, December 12, 1912. His funeral was held at Westminister Abby, an honor never before given an American. It was attended by king and nobility of England and representatives of all nations of the world. The English Government sent the body home to New York on a large battleship. His funeral at New York City was held in the Episcopalian Cathedral on Morning Heights. His funeral here was attended by the President, Cabinet, Judges of Supreme Court, Congressman and representatives of all nations of the world. He rests in Sleepy Hollow, Tarrytown, New York, within two feet of the grave of Washington Irving, where he quietly awaits the Resurrection Morn.

REV. PARKS JACKSON. 


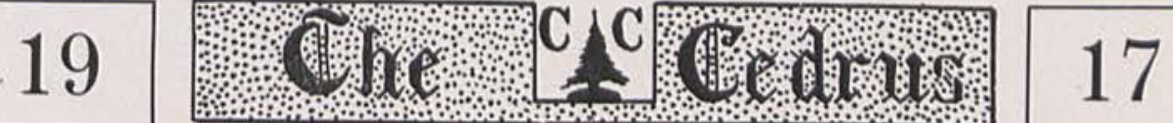

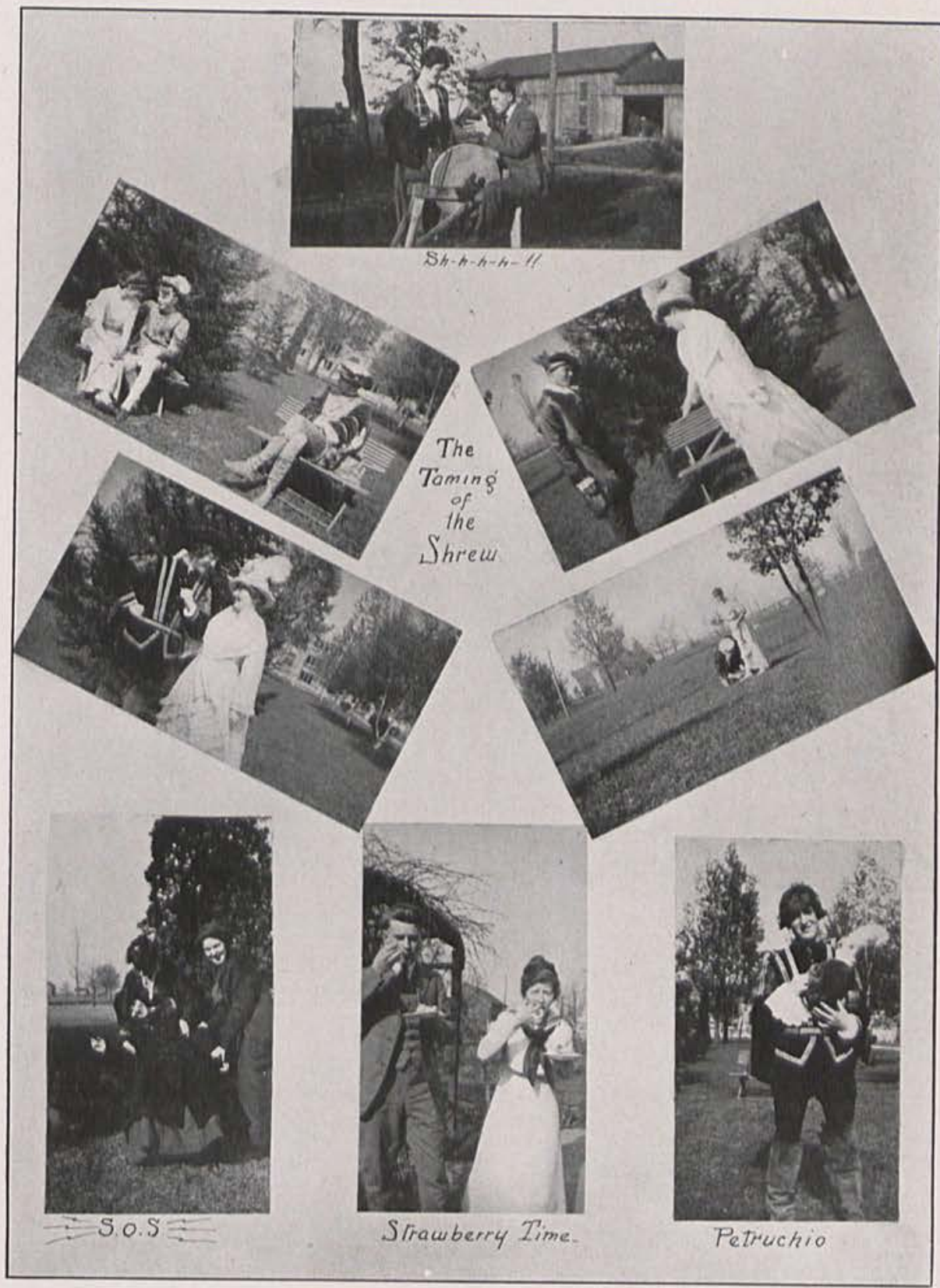




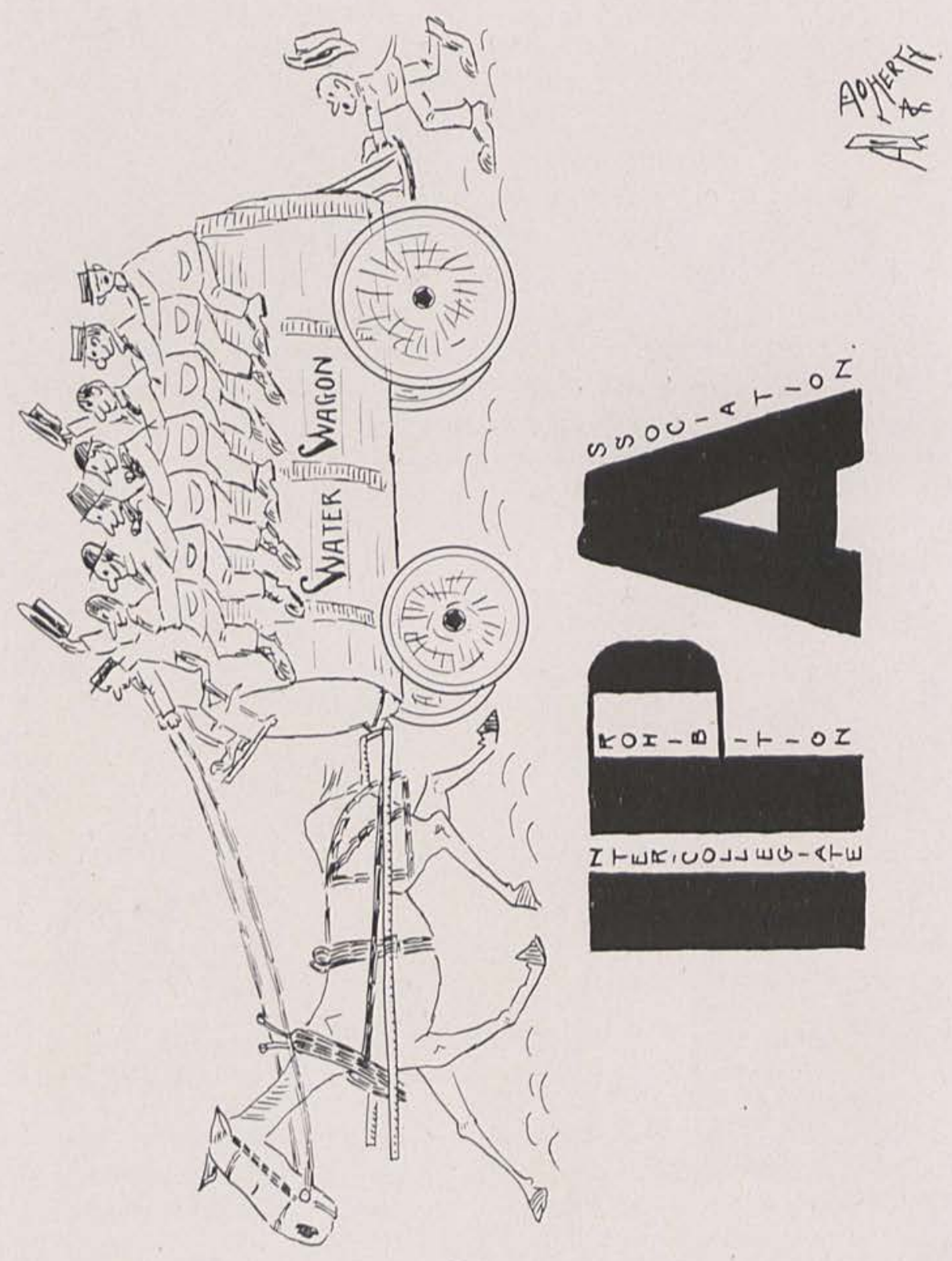




\section{9}
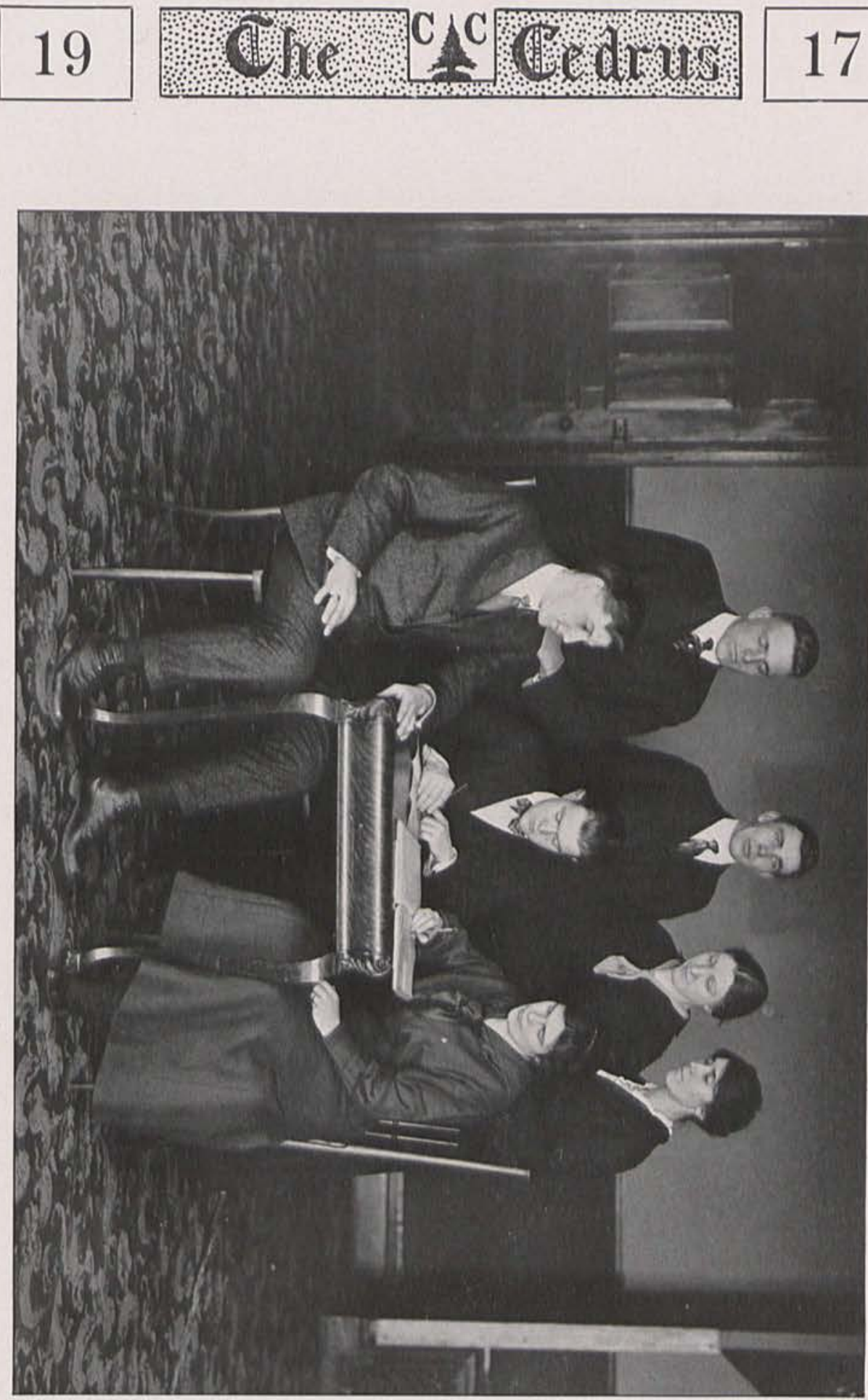


\section{Intercollegiate Prohibition Association of Cedarville College}

$\mathrm{O}$ $\mathrm{N}$ the 9 th of November, 1916, thru the influence of Mr. William McIntyre of Xenia Seminary, the Intercollegiate Prohibition Association of Cedarville College, was organized with a membership of thirty-one boys and girls.

Ralph Elder was elected president of the new organization, the other members of the executive committee being a secretary, treasurer, and reporter.

The first move of the new association was to send three delegates to the national convention, which was held at Lexington, Kentucky, December 28th-31st. This convention of over seven hundred delegates proved to be one of the greatest student conventions ever held in this country. Among the many prominent speakers at this convention were W. J. Bryan, Ira Landrith, Daniel Poling, Ex-Gov. Foss, Col. Bain and many others of national reputation. Each in turn answered the challenge of the national prohibition movement.

One of the most interesting features of the convention was the oratorical contest, in which there were eight contestants. The first prize went to Joshua B. Lee of Oklahoma, the winner over 1600 college orators.

Since the oratorical contest is one of the prominent features of the I. P. A. movement, our organization has decided to hold a preliminary contest, the winner to represent our college at Xenia, where the contest for this section of the state is to be held.

The I. P. A. through its activities presents splendid opportunities for prohibition work, and it is our earnest desire and sincere wish that every college student do all in his power to help attain our aim of Ohio Dry after Nov. 6th; A dry nation in 1920.

J. W. C. 

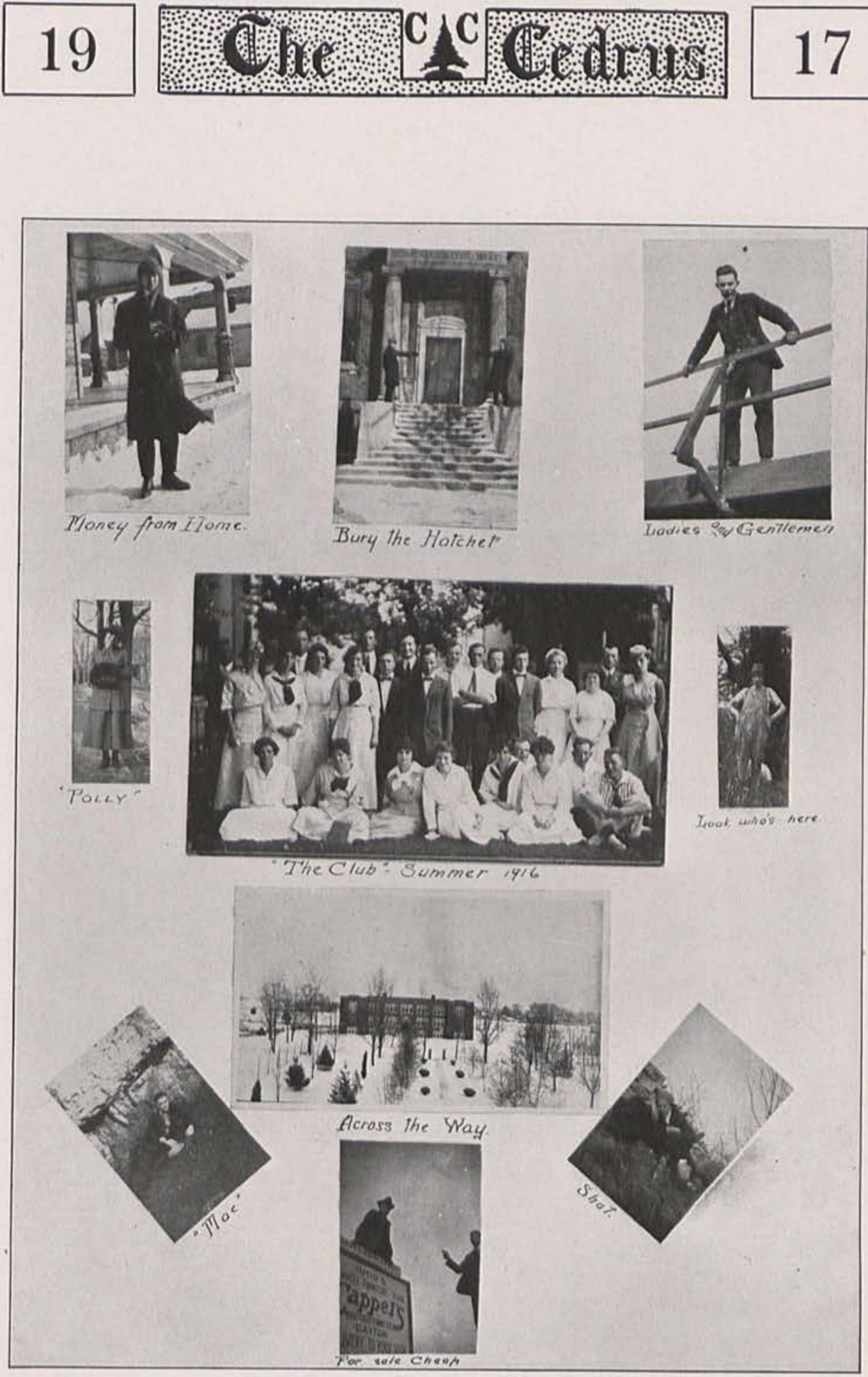


\section{9 ofro CAdrut 17}

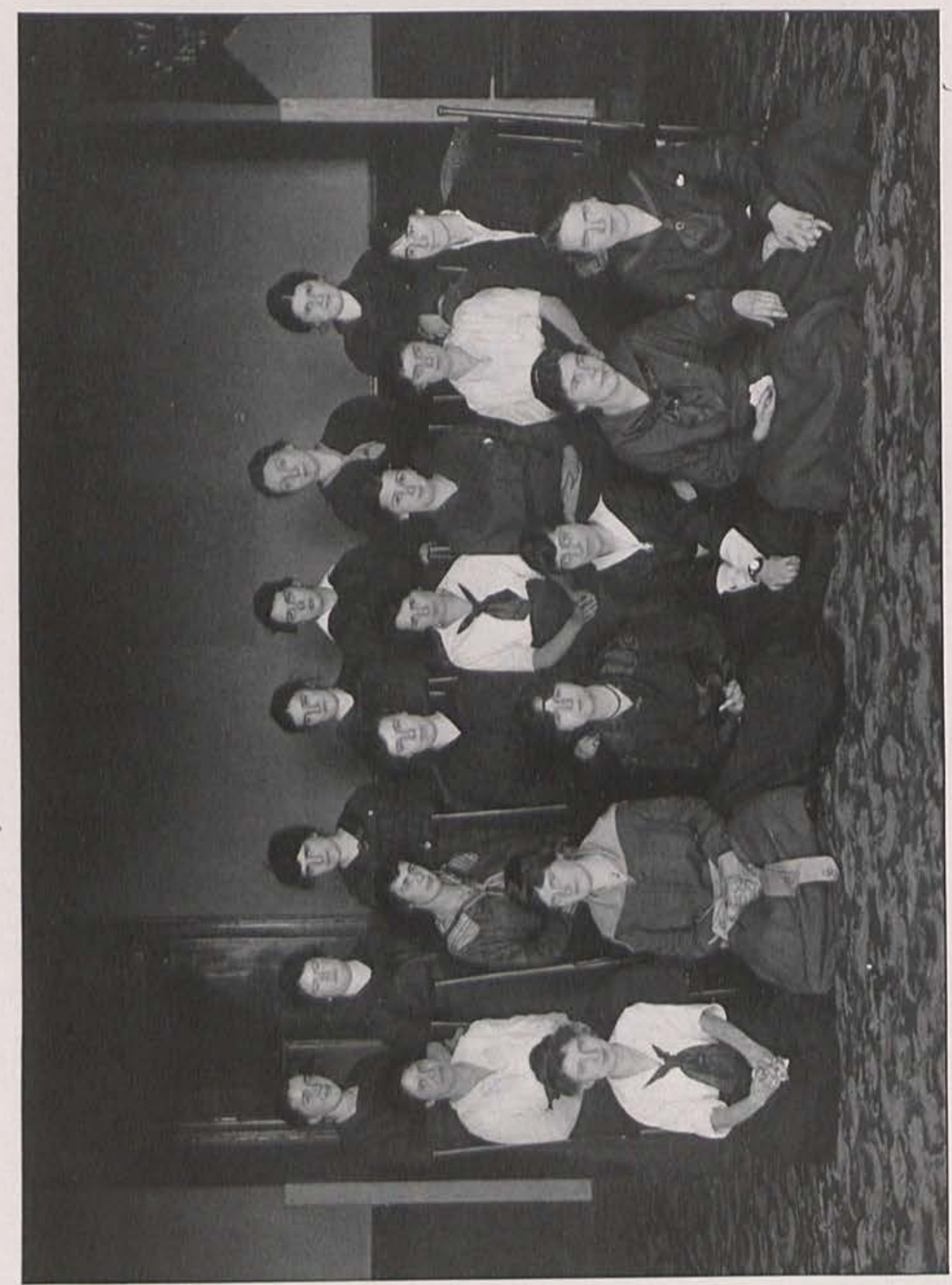




\section{9}

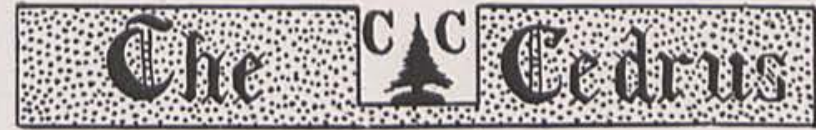

\section{Young Women's Christian Association}

W

HEN the Young Women's Christain Association is spoken of, our minds naturally revert to the thought of Christian girlhood with weekly meetings of devotion.

The Young Women's Christian Association of Cedarville College, ever since it was organized in 1909, has been a help to the girls, spiritually and socially, and has opened up many new paths for them.

Since the beginning of our organization we have prospered according as our interest has increased. The year 1916-17 has been one of growth in membership and interest. Fourteen new members have been enrolled this year. In November our organization sent fifteen dollars to the war stricken Armenians. In February a delegate was sent to the Student Volunteer Convention which was held at New Concord, Ohio.

Our meetings which have been held every Wednesday morning have been very interesting.

A splendid talk was given one morning by the Ohio-West Virginia field secretary, Miss Ward. She emphasized the fact that our life each day is a test of our religion.

We trust that the interest already manifested will continue in the years to follow and that the time will come when all of the college girls will belong to the association.

We hope that the influence that may be imprinted on the girls' characters will be an aid to them in the future and that our Y. W. C. A. may be a bond that will link the girls together and press them toward the mark for the prize of the high calling of Christ Jesus, for

One smile can glorify a day,

One word true hope impart;

The least disciple need not say,

There are no alms to give away,

If love is in the heart.

J. M. C. 


\section{9}

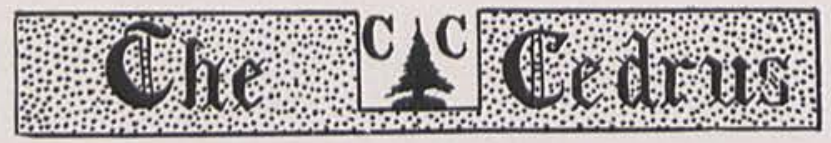

17

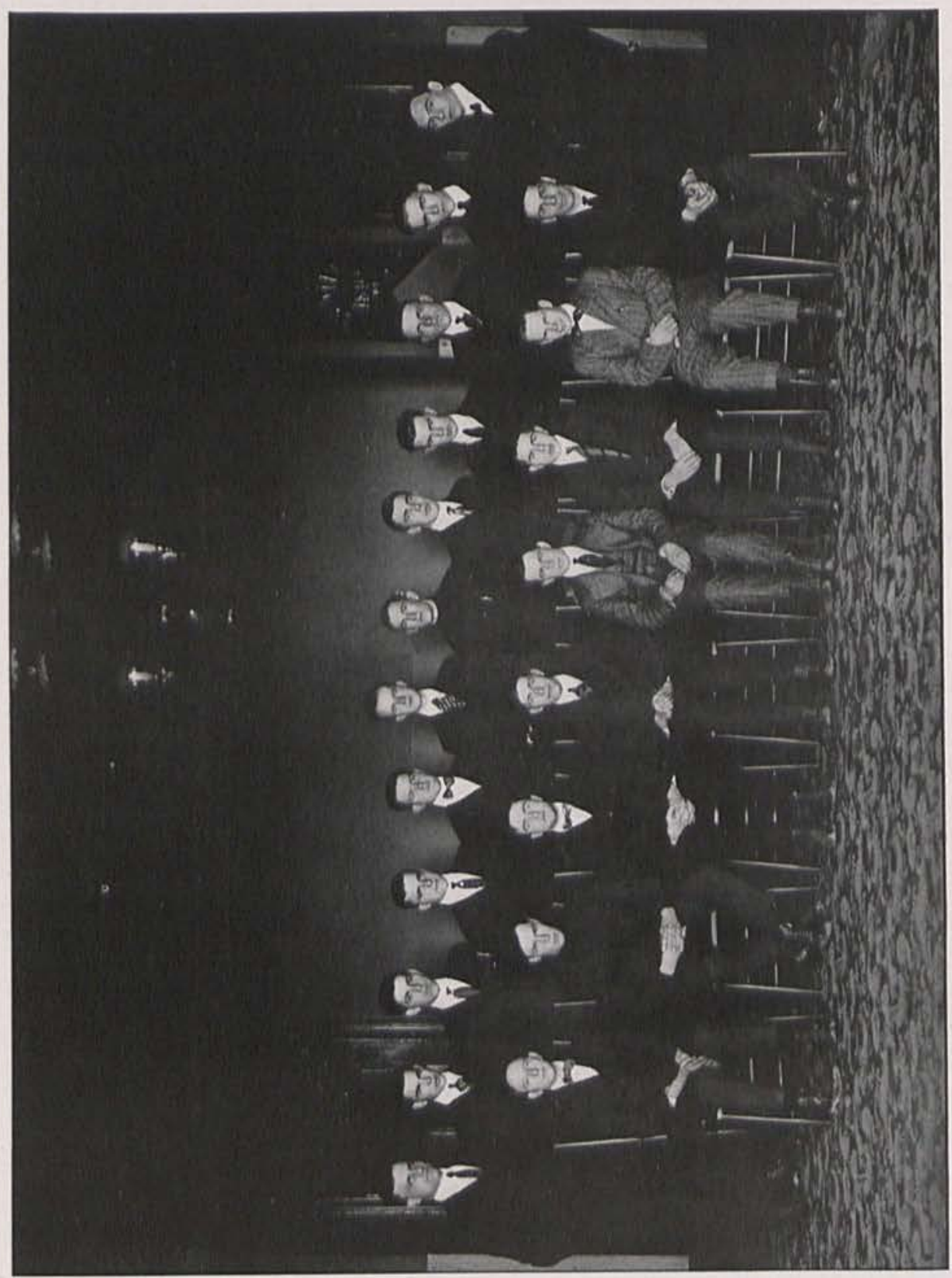




\section{9}

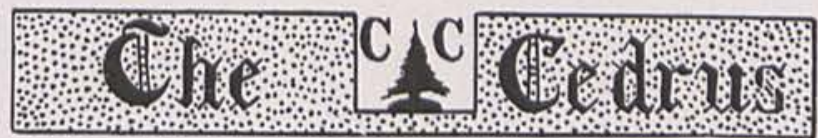

\section{Young Men's Christian Association}

$\mathrm{T}$

VHE Y. M. C. A. stands out among all of the other organizations of college life, as one whose social benefits and Christian training helps to mold the lives of all its members into the true service of Christ.

Our association was organized in 1906. Since that time it has helped the young men of Cedarville College to live purer and more useful lives. Moreover it has influenced some to enlist in the Ministerial and Missionary fields. Two former members, William Waide and Professor Lanning, have gone to the foreign fields as missionaries. Mr. Waide is in India. He was married last February to a lady missionary, who no doubt will be much help to him in his work. Mr. Lanning and his wife, also a graduate of Cedarville College, are doing a splendid work in China.

The membership of our association has increased this year, and a deep interest seems to be manifested by each member. Each one tries to do his part by giving a brief talk or prayer in each meeting.

Dr. Chesnut gave us a very practical and instructive address on the subject, "Unappreciated Service."

Early in the first semester the Y. W. C. A. and Y. M. C. A. entertained the college students at the home of Mr. William Anderson.

Our association was represented at the Student Volunteer Movement Convention held at Concord, Ohio, February 2nd, 3rd and 4th.

On March 9th Robert Coleman, our president, went to the Y. W. C. A. state conference which was held at Columbus, Ohio.

This gives a brief outline of our work done this year and our prayer for the years to follow is that the Lord will bless us and keep us that we may labor for the honor and glory of God.

$$
\text { P. W. D. }
$$




\section{9}

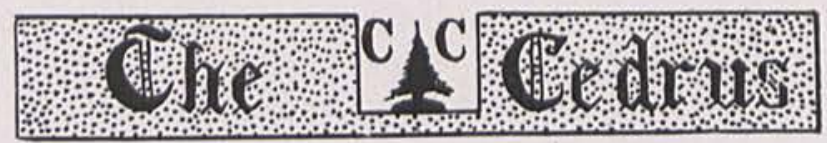

17

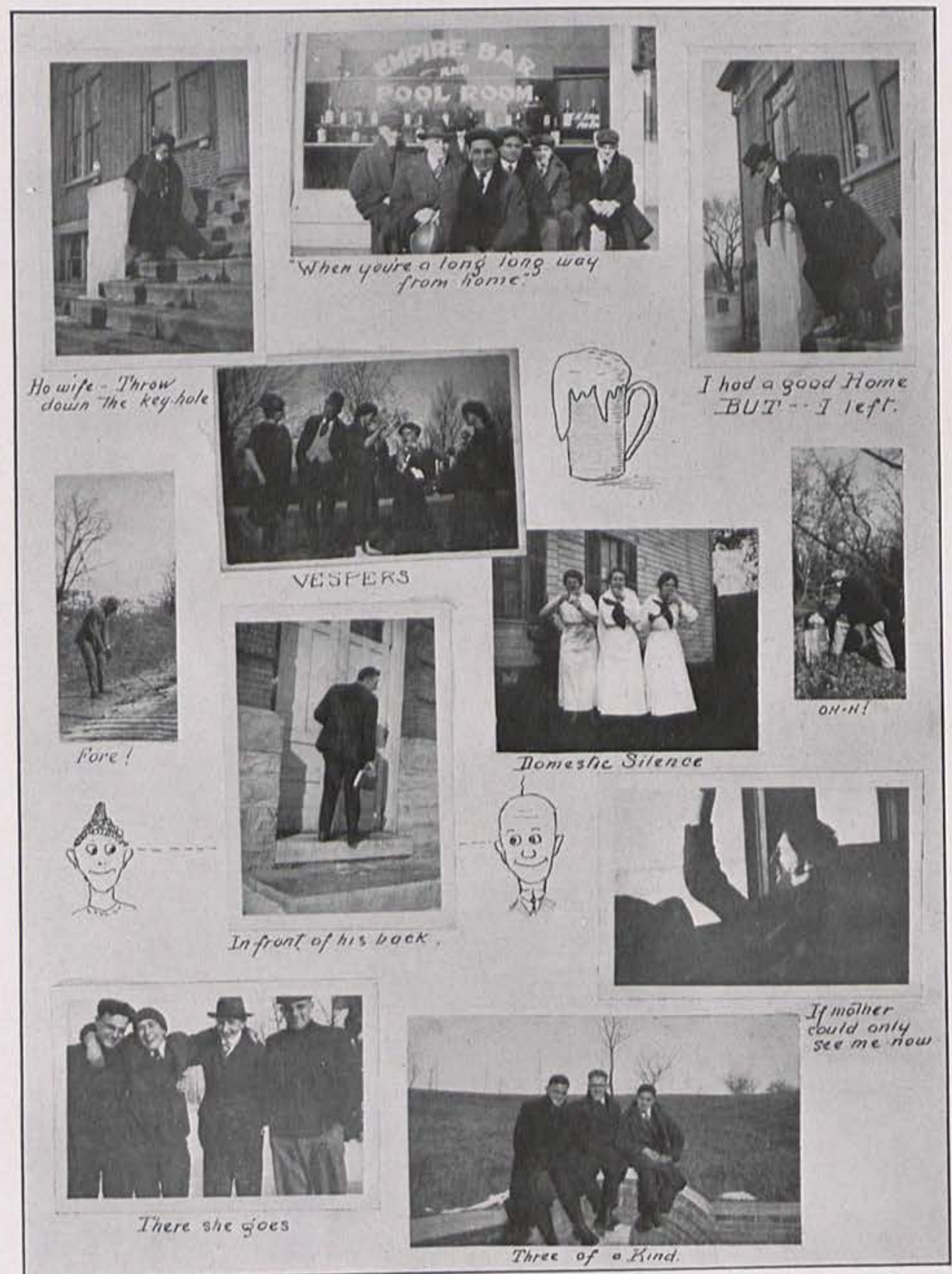




\section{Alumni}

"See how far that little candle throws its beams,

So shines a good deed in a naughty world."

$\mathrm{A}$

LTHO Cedarville College is small, her deeds and her influence are Worldwide. In looking over the list of alumni we find that they are found in many states of our nation; they are found in Nova Scotia, India, Africa, China, and one of precious memory lies buried in Japan; they occupy places of responsibility wherever they are; and they carry with them the Christian character and training they have gained in Cedarville College. Cedarville College is as a little candle in a big world and yet her light encircles the globe.

We have listed the alumni according to the professions and occupations which they have entered, in order that those who read may know just what Cedarville has done to supply the constant demand for trained men of sound character.

Professors and Teachers: C. C. Morton, '97; Cornelius B. Collins, '99; Isabelle M. Winter, '99; Cora A. Anderson, '00; J. R. Harper, '00; Bertha L. Knott,'00; G. A. Harper, '01; Vera Andrew, '03; Agnes K. Stormont, '03; S. C. Wright, '03; Lillian L. Connor, '04; J. R. Fitzpatrick, '04; Carrie M. Rife, '04; Frank H. Young, '04; J. E. Shaw, '06; Caroline Finney, 08; Elmer G. Spahr, ’08; Mrs. Ada Clow, '10; R. Fred Bird,'10; Alberta Creswell, '10; Della M. McCann, '10; Ethel I. MeMillan, '10; Frank M. Reynolds, '11; J. O. Stewart, '11; Bertha A. Stormont '11; Florence J. Williamson, '11; Martha M. Anderson, '12; Bertha I. Anderson, '13; Nancy E. Finney, '14; Hazel V. Lowry, '14; Grace Morton, '14; Harry F. Bird, '15; R. C. Burns, '15; Cameron M. Ross, '15; Wilmah Spencer, '15; W. D. Sterrett, '15; David C. Bradfute, 16; J. Merle Rife, '16; Carey P. Ritchie, '16; Orland M. Ritchie, '16; G. F. Siegler, '16; Ada F. Wallace, '16.

Preachers: John W. Bickett, '97; Raymond P. Gorbold, '97; Homer MeMillan '97; J. Alvin Orr, '97; James M. McQuilkin, '98; James Heron, '99; Thomas R. Turner, '99; Walter A. Condon, '00; W. Wallace Iliffe, '00; B. McLeod Paul, '00; Clarence A. Young, '00; Robert C. Galbreath, '01; Robert B. Wilson, '01; Homer B. Henderson, '02; John J. Wilson, '03; William A. Pollock, '04; William R. Graham, '05; Milton G. Hanna, '05; Walter W. Morton, '06; Clarence G. Ware, '07; William Hawthorne, '09; Ernest B. McClellan, '09; William Waide, '09; David J. Brigham, '10; Andrew S. Creswell, '10; William W. Ritter, '10; Edward B. Shaw, '10; Robert W. Ustick, '11; Walter P. Harriman, '12; S. Ernest Foster, '13; Wendell F. Foster, '13; Thomas Whyte, '14.

Physicians: Elmer A. Elder, '98; John Cecil George, '01; John M. Finney, '03; Claude B. Estle, '06; George C. Stewart, '07; Charles L. Baskin, '07.

Lawyers: John F. Anderson, '01; J. Frederick Barber, '04; Joseph A. Finney, '06; J. Carl Marshall. '07; Leroy T. Marshall, '07; J. Kenneth Williamson, '10.

Missionaries: Raymond P. Gorbold, '97; Kioto, Japan, (Deceased). Miss Alfaretta Hammond, 03, Beni Suef, Egypt; Mr. William Waide, 09, Roorkee, India; Wilhelmina (Mitray) Lanning, '12, Teng Chow Fu, China.

Lack of time and space make it impossible to list the names of those who have entered some of the less public walks of life. However, altho they may not have their names listed here, altho they are not quite so conspicuous to the public, yet they are known. They are filling their places well and Cedarville is justly proud of her alumni. 


\section{9

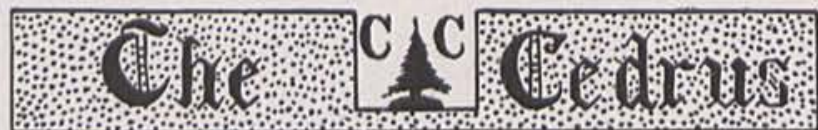

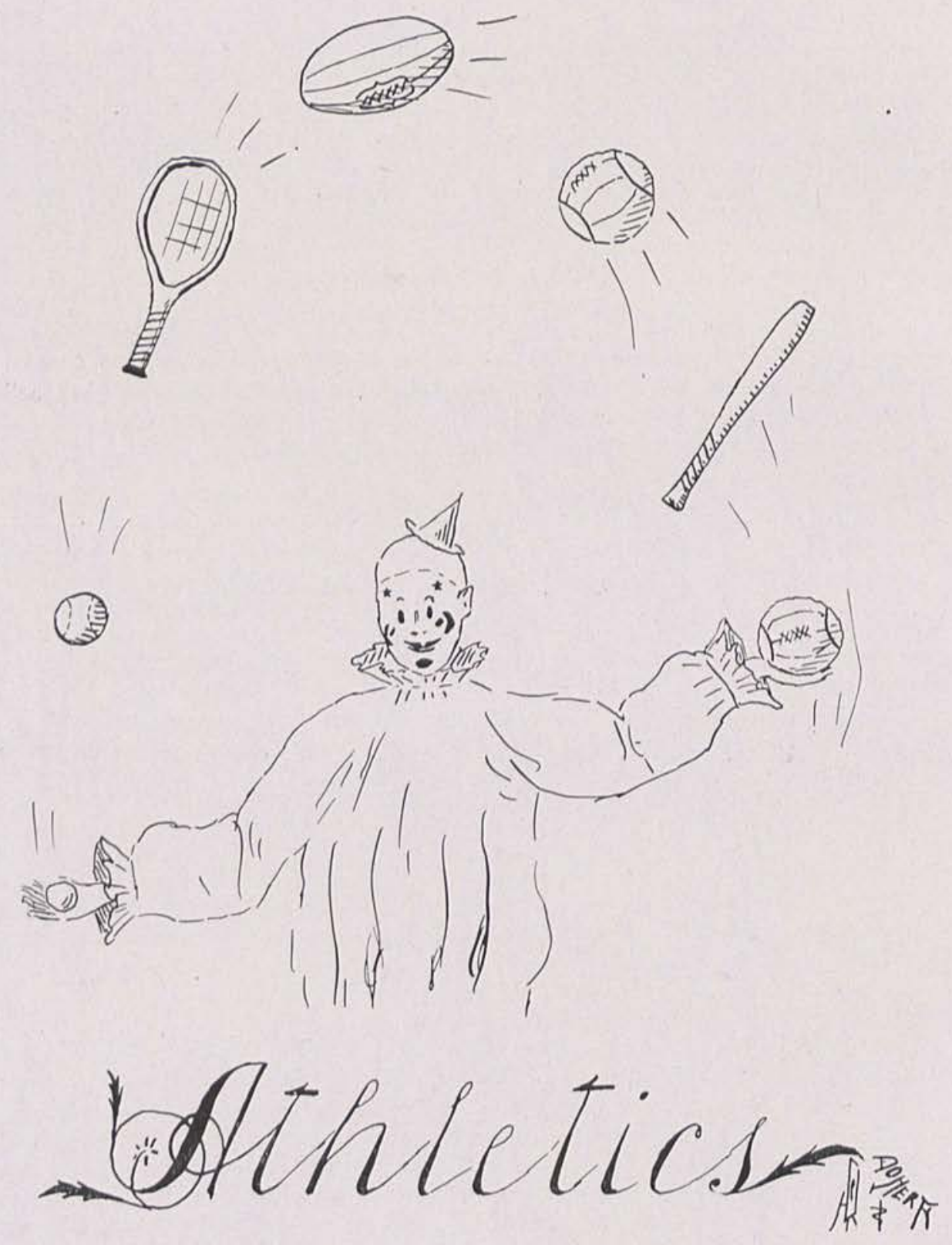




\section{9

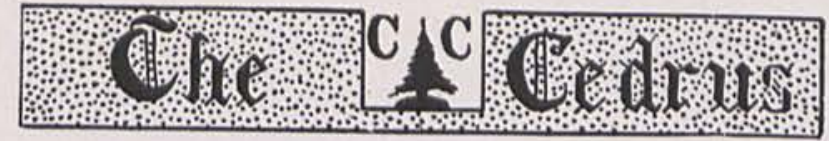

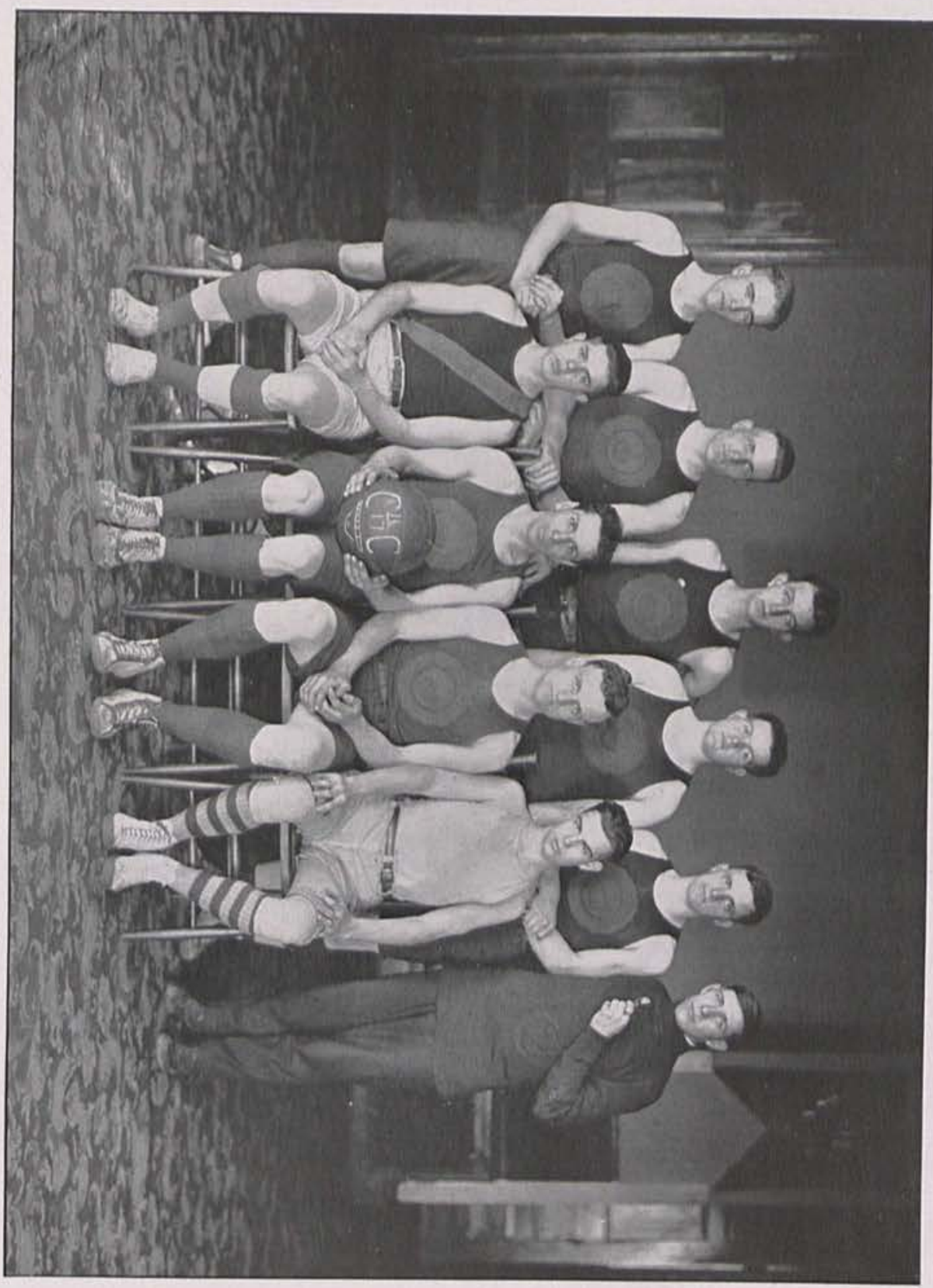




\section{Boys' Basket Ball}

$\mathrm{T}$

HIS year brought to the basket ball fans of Cedarville some of the best basket ball that the college has furnished for several years; in fact the best since back in 1909 when Palmer, Williamson, Dixon and Co. represented the college.

When the first call for practice was given the largest and most likely looking bunch of aspirants that we have had for several years came out. There were fifteen in all: five of last year's varsity; Kennon, J. Collins, Chesnut, Cornwell and W. Collins, R. Collins from the year before; Smith, Foster and William Anderson from last year's second team and six new fellows, McClure, Horton, Creswell, Wallace Anderson, Clark and Wright.

Tom Kennon, who has had two years of experience, was elected captain, and practice began immediately for the first game.

Before the first game was played the captain selected nine men for the first team squad; J. Collins, R. Collins, Kennon, Cornwell, W. Collins, Horton, McClure and Chesnut.

The first game was played on December 15 th with the Springfield Y. M. C. A. Pirates. Although having had but two weeks of practice, the team put up a fast game and won with a score of 52 to 20 .

A game scheduled for the next week with Bliss College had to be cancelled because of the scarlet fever epidemic.

On the first Friday after vacation, without having had any practice for three weeks and with one of our regulars out of the game, we went to Wilmington and lost the first game of the season to that college, 34 to 15 .

The next two games, with Sabina Crescents and Bethel Collegians, were easy victories, 87 to 31 and 61 to 31 .

The next two games were played away from home; one with Ashland College and the other with Muskingum College. In the game with Ashland we won, 32 to 21. The game with Muskingum on the next night was about the fastest of the year. Muskingum has acquired quite a reputation in basket ball in the last few years. They expected to "snow us under," as they did three years ago. However, we sprang a little surprise on them, holding them to a 51 to 40 score.

The next week we got revenge on Wilmington College for the defeat they handed us earlier in the season, defeating them 36 to 24 .

On the next Saturday night, with three of the regular team on the crippled list, we received the only bad defeat of the season, when Antioch "snowed us under" on their floor, 57 to 24 . After the Antioch disaster we rested up for several days and then went after it "hammer and tongs"to even the score with Antioch.

In the meantime we won a fast game from Willis College, 58 to 34 .

Space will not permit much to be said, concerning the second Antioch game, but it is sufficient to say that we gained revenge in the fastest game played at home during the season by the score of 26 to 20 .

With six straight games won on our own floor we hoped to finish the season without losing, but Muskingum destroyed this hope by defeating us on March 1st; score 36 to 26

On the following night we finished our home schedule by winning from the Indiana State School for Deaf; score 42 to 26.

Two weeks following we went to Columbus and played the State School for Deaf, having had but one practice in two weeks. The Mutes had not lost a game during the year: so we decided not to break their record, and so we lost the game by a score of 39 to 34 . 


\section{Scores}

Cedarville

Cedarville.

Cedarville

Cedarville

Cedarville

Cedarville

Cedarville.

Cedarville

Cedarville

Cedarville

Cedarville

Cedarville

Cedarville

Cedarville

Total
52

15

80

61

32

40

36

24

18

58

26

26

42

34

544
Springfield Y. M. C. A. . . . . . . 20

Wilmington College ........... 34

Sabina Crescents. .............. 7

Bethel Collegians. . . . . . . . . . . 31

Ashland College............... 21

Muskingum College. .......... 51

Wilmington College........... 24

Antioch College ............... 57

Sabina Athletics. . . . . . . . . . . . 31

.Willis College. . . . . . . . . . . . . . 34

Antioch College .............. 20

Muskingum College. .......... 36

I. S. S. D................. 26

O. S. S. D. . . . . . . . . . . . 39

Total 431

INDIVIDUAL SCORES

Field Goals

R. Collins, F.

Foul Goals

Cornwell, F.

J. Collins, C. . . . . . . . . . . . . . . . . 50

Kennon, G. . . . . . . . . . . . . . . . . . 7

W. Collins, G. . . . . . . . . . . . . . . . . . 40

Horton, F. . . . . . . . . . . . . . . . . 5

Creswell, F. . . . . . . . . . . . . . . . . . . 1

Chesnut, F. . . . . . . . . . . . . . . . \& 


\section{9}
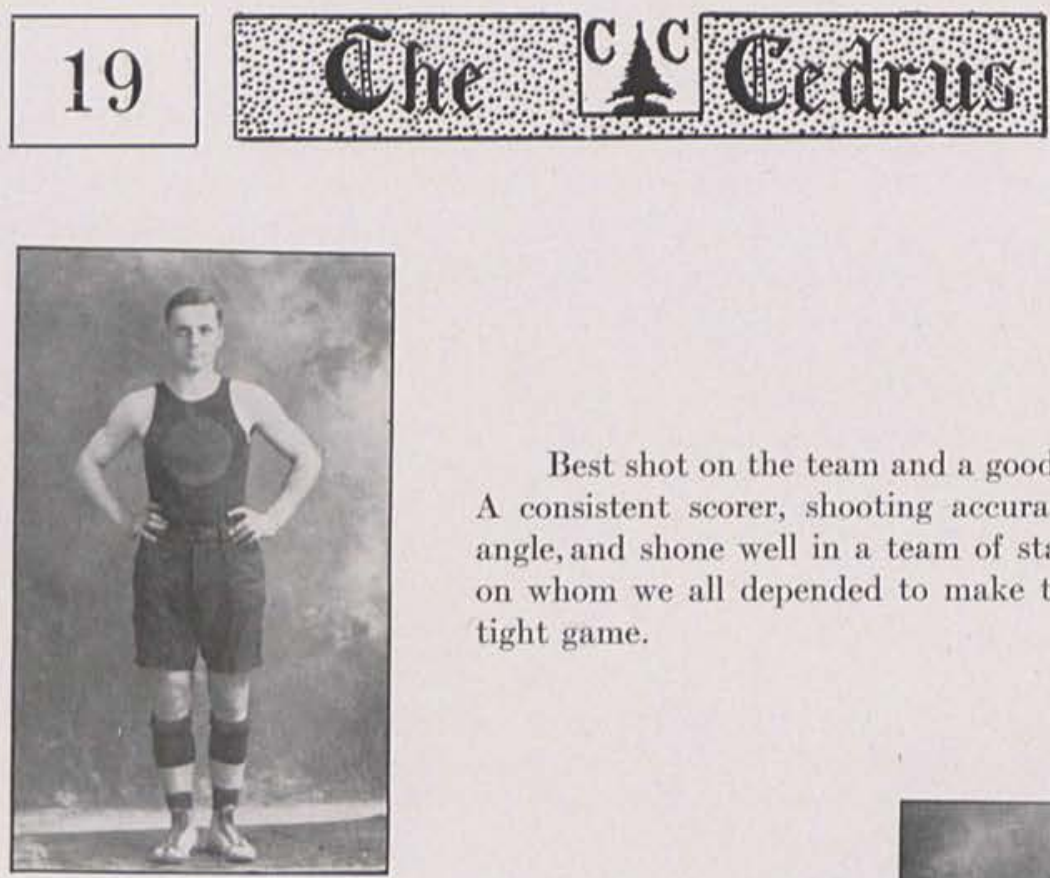

Best shot on the team and a good heady player. A consistent scorer, shooting accurately from any angle, and shone well in a team of stars. The man on whom we all depended to make the points in a tight game.

High Pockets or Ollie, as he is best known, was an "excellent" running mate for Rodge. It was a common occurrence for the opposing team to change guards on Ollie. Favorite expression is "I'll get you, American Brothers."
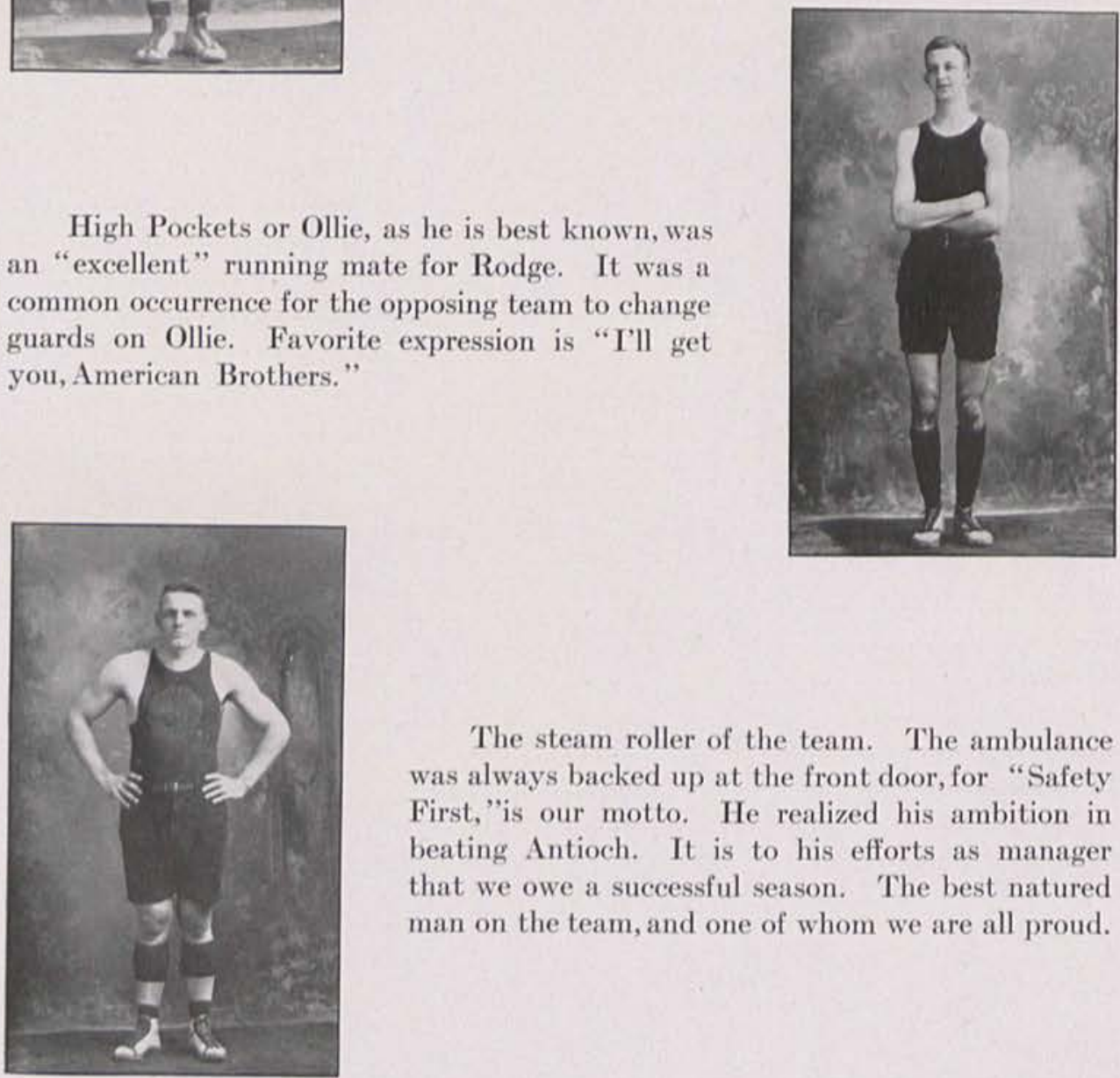

The steam roller of the team. The ambulance was always backed up at the front door, for "Safety First," is our motto. He realized his ambition in beating Antioch. It is to his efforts as manager that we owe a successful season. The best natured man on the team, and one of whom we are all proud. 


\section{9}

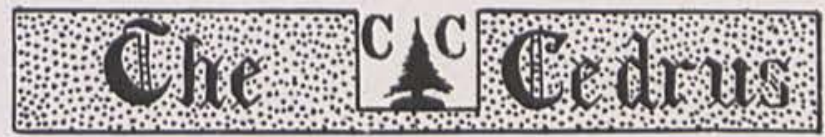

17

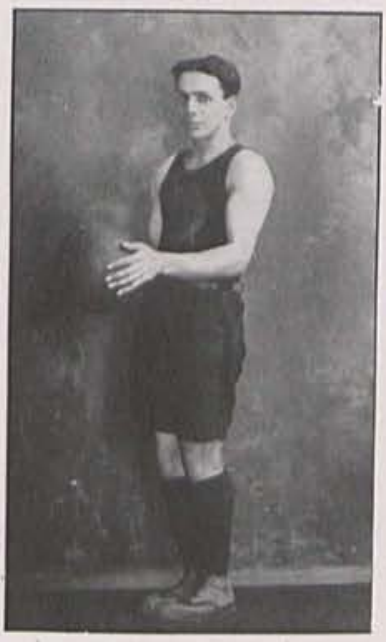

Tom as captain made a good leader. The forward who made more than 3 goals off Tom was a "good one." The best dribbler on the team. Did not make many points himself, but spoiled many a one for the opposing team.

Bill is always full of "pep," and worked hard in every game. The foul thrower of the team, being a steady and consistent shot from the free line.
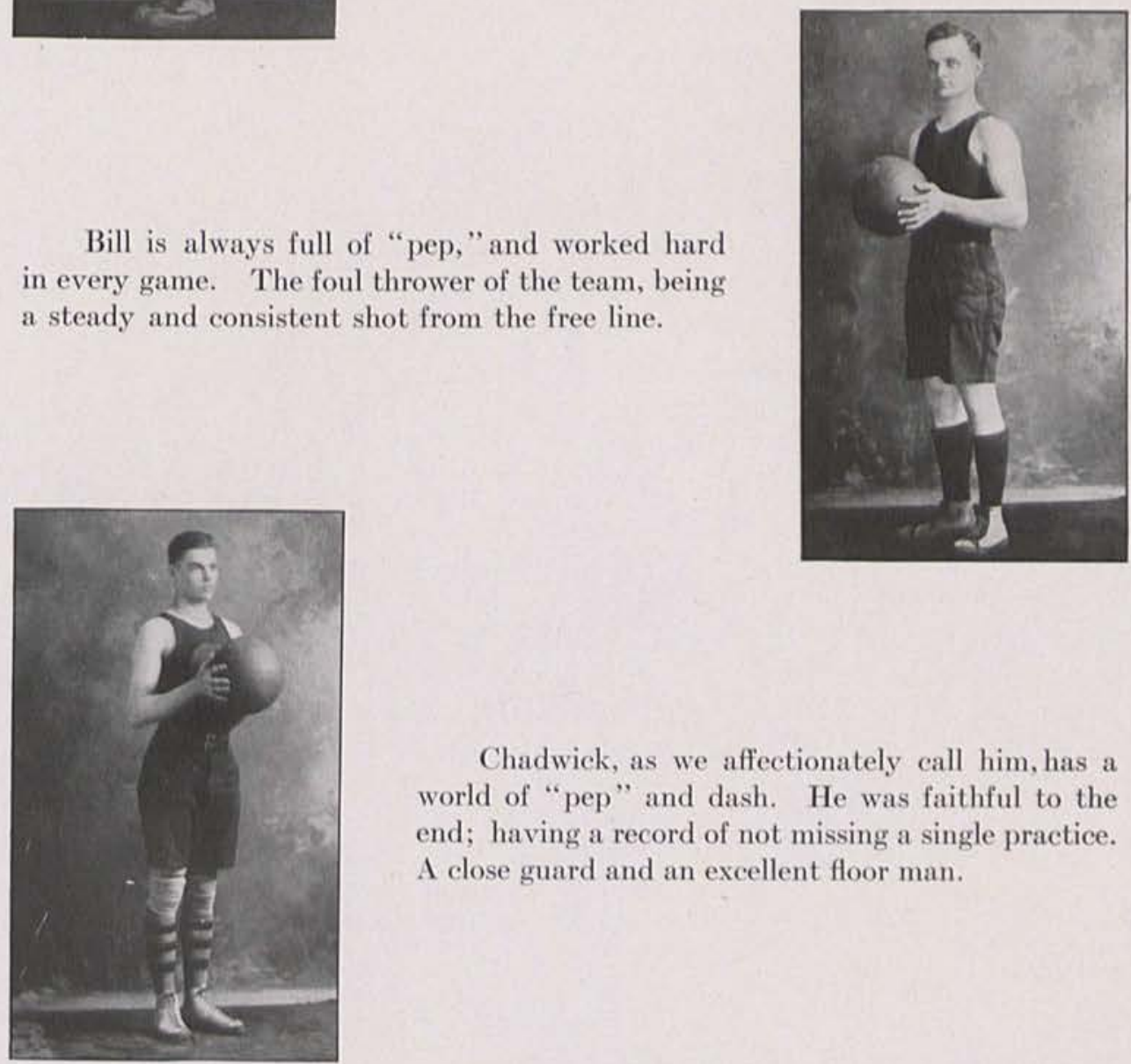

Chadwick, as we affectionately call him, has a world of "pep" and dash. He was faithful to the end; having a record of not missing a single practice. A close guard and an excellent floor man. 


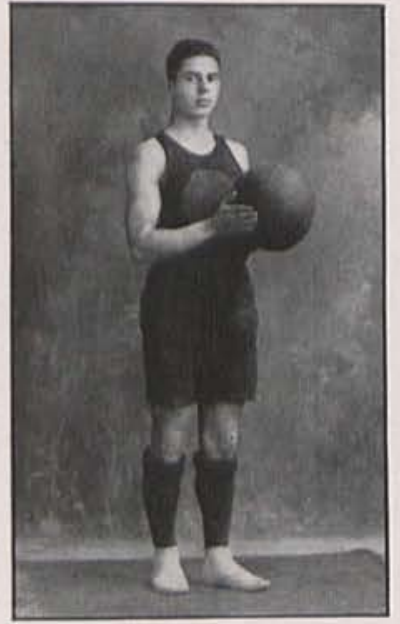

Clif was the main-stay of the second team at the forward position. A sure shot and an exceptionally fast floor man. Though short in stature he is "right there with the goods" and can hold his own with the "best of 'em."

Morton was captain of the second team and made an excellent running-mate for Horton at forward. An accurate shot and a good passer. Could make more long shots than any one on either team.

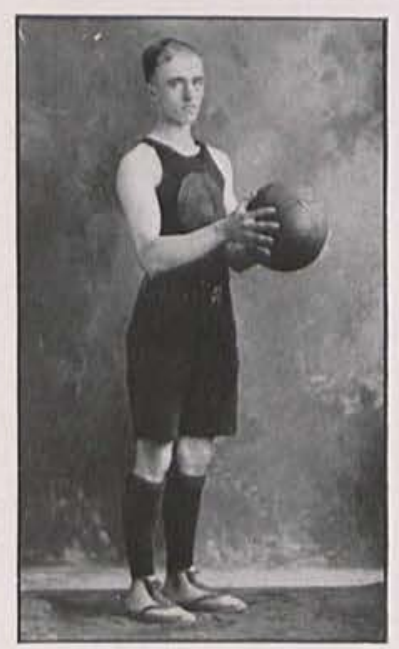



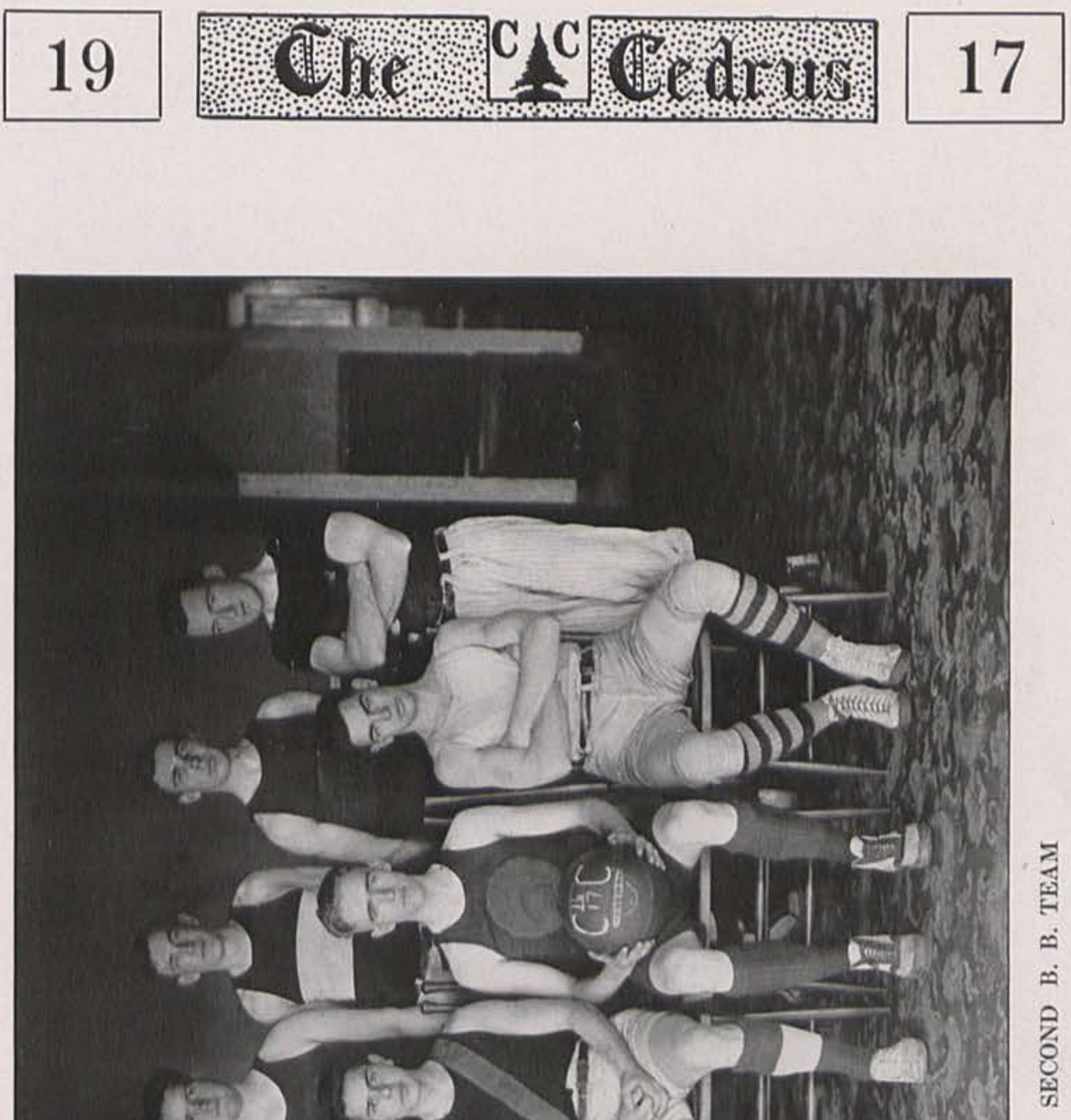


\section{9}

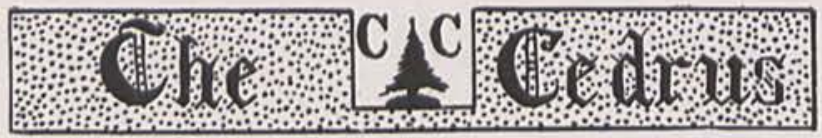

\section{Second Basket Ball Team}

$\mathrm{T}$

WE success of the first team was due largely to the practice given them by the second team. It is not an easy thing to practice day after day with no incentive but that of giving the first team practice. However, it need not be supposed that the first team was always able to beat the second team by a large score, for there were some days when the seconds turned the tables and beat the first team. The second team was always able to put up a good stiff practice game.

The second team played four games and won three of the four. They defeated Antioch second team 14 to 7, Jamestown High School 23 to 20 and Clifton Alumni 38 to 24 . The only game lost was to the local high school; a very fast game; score 29 to 27.

Beside the three second-team men included on the varsity squad, Wallace Anderson, Clarke, and Foster deserve special mention for their faithfulness in practice.

\section{SECOND TEAM SCORES}

C. C. Seconds

C. C. Seconds

C. C. Seconds

C. C. Seconds
14

23

27

38

102
Antioch Seconds............. 7

Jamestown H. S. . . . . . . . . . . . 20

Cedarville H. S. . . . . . . . . . . . 29

Clifton Alumni................. 24 


\section{9

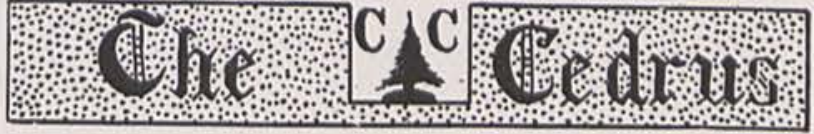

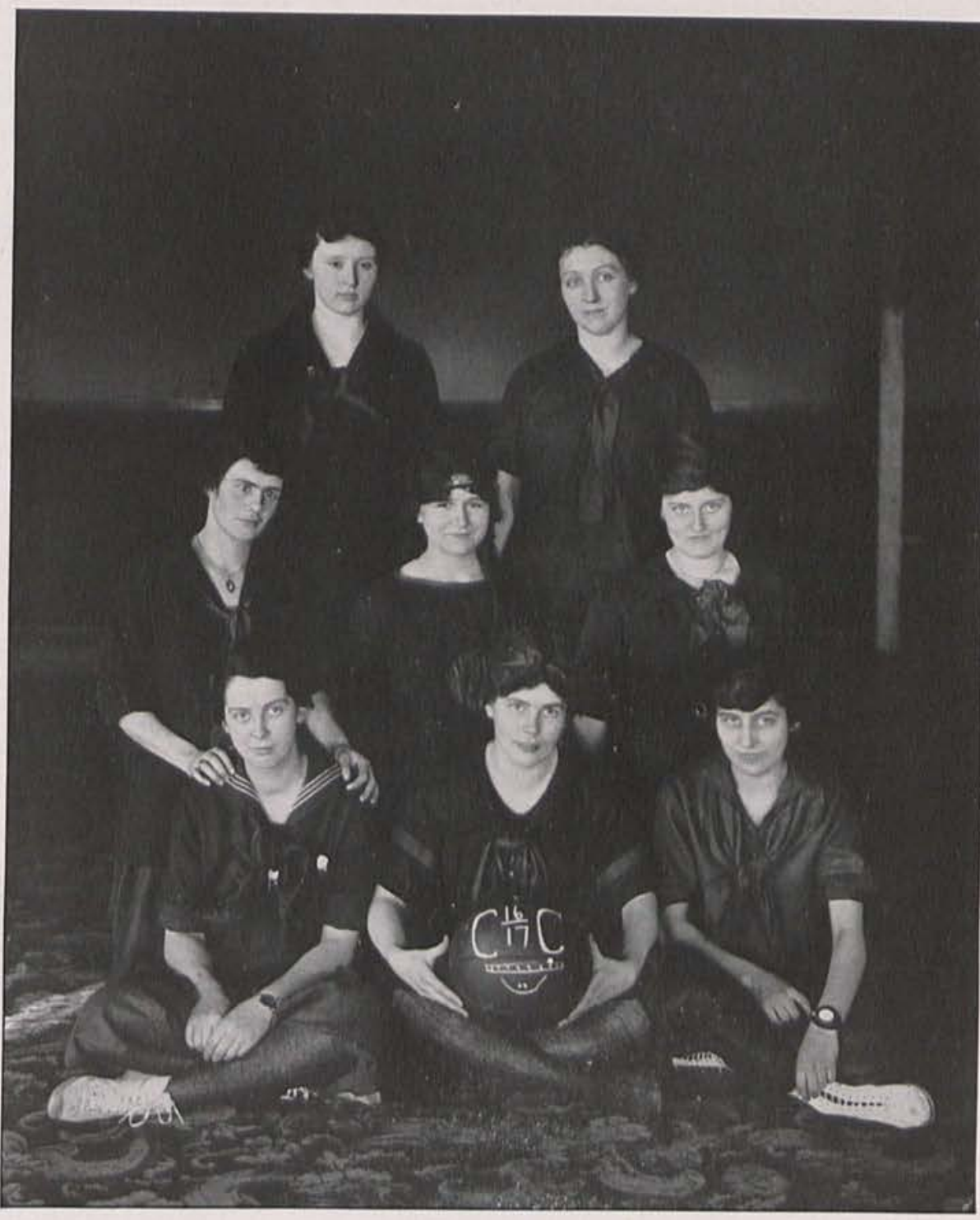




\section{9}

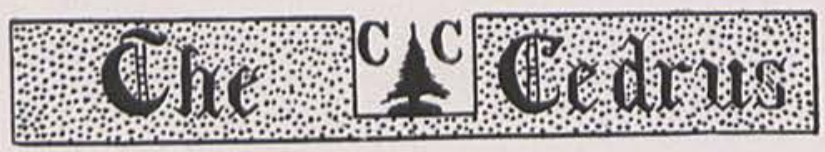

\section{Girls' Basket Ball Team}

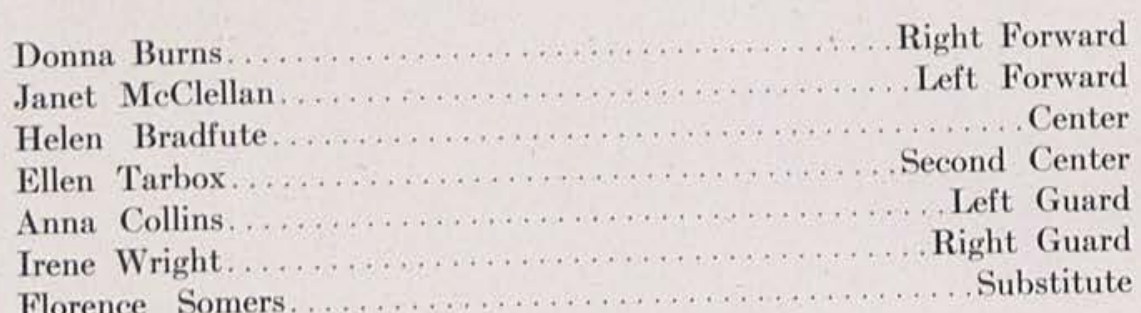

"To exist or not to exist," that was the question.

Did we win any games? Of course we did. Cedarville College girls always win some games. But let's not take the time to count our victories this season, for -well, we hate to boast, and then you could'nt remember all of them, so what is the use, for we want to take time to tell you of our score at Middletown.

Did you ever buy a little penny fire cracker? Did you ever put a little match to one? And did you ever hear the little sound it made? Sizzle! Sizzle! Sizzle! Well, the next time you light one, you can think of our side of that score. Nuff said!!!

But

We did'nt give up hoping though the ship went down.

We grabbed a spar or something, we just refused to drown.

We didn't think we were killed, just because we were hit,

But we smiled in the face of danger, and stuck to our grit. 


\section{9

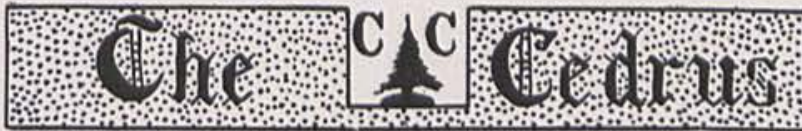 \\ 17}

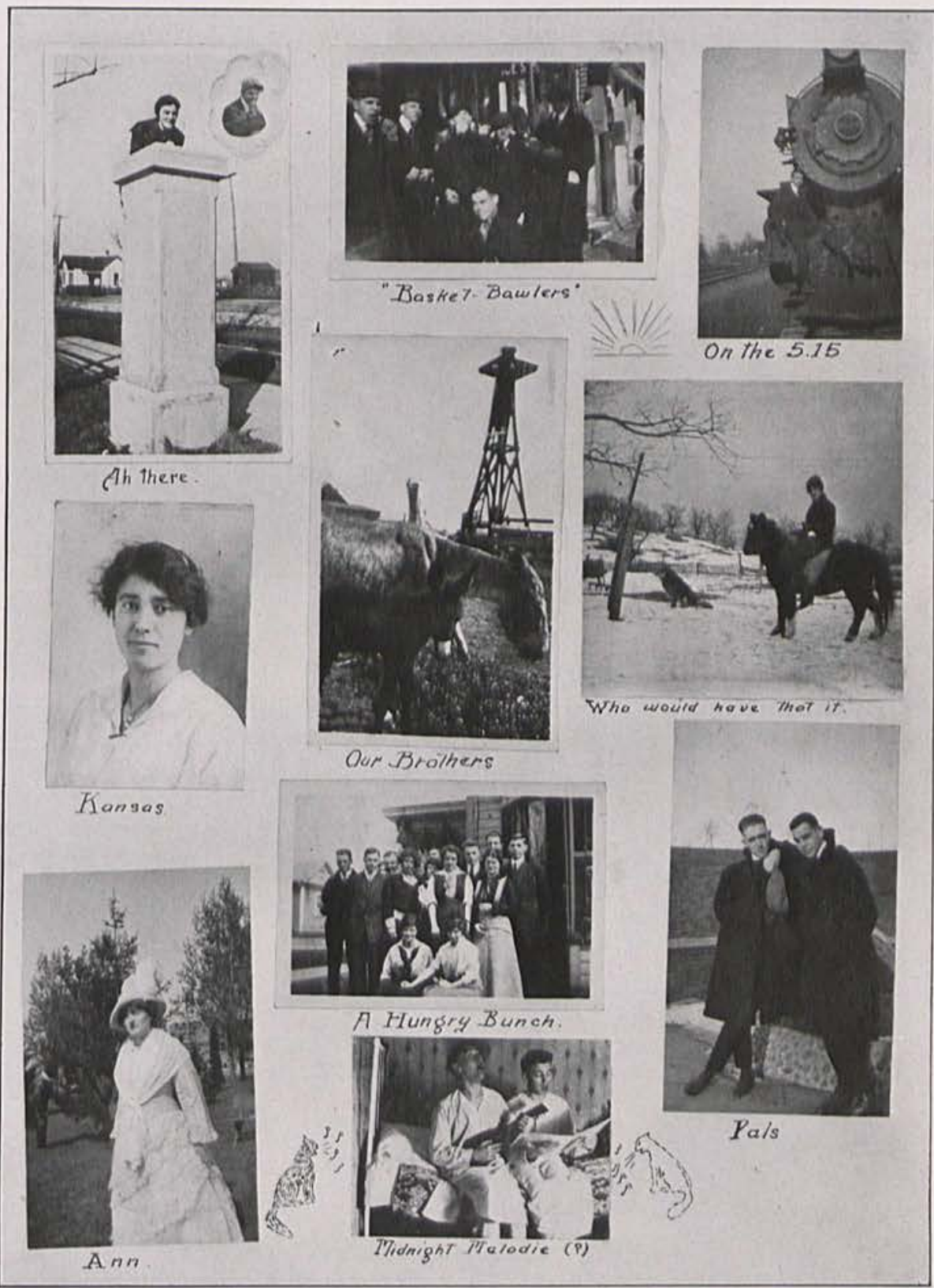




\section{9}

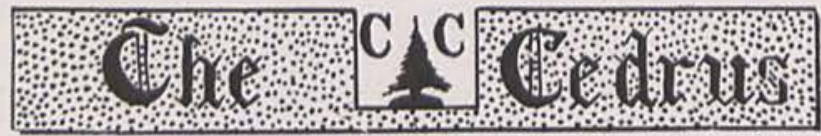

17

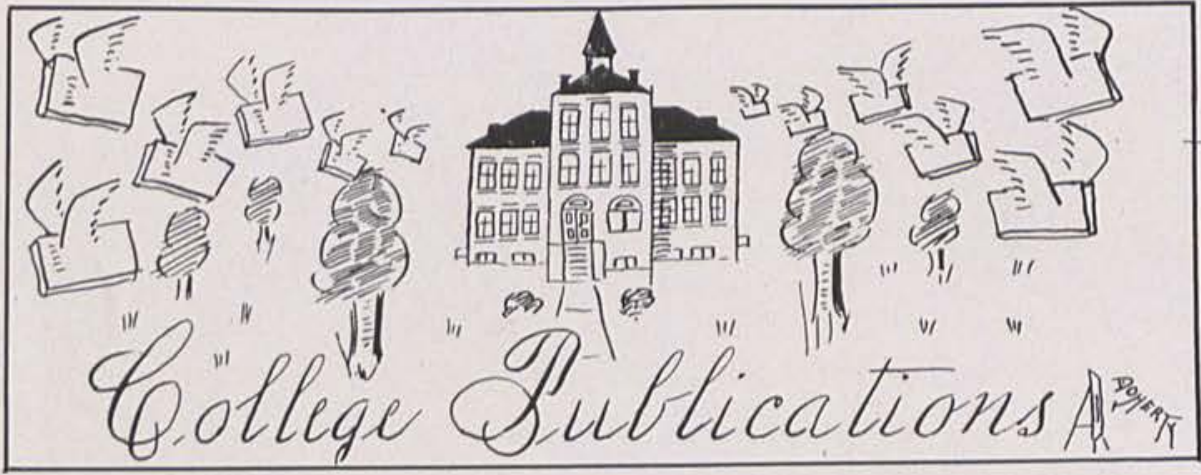

\section{"The Cedrus"}

NHIS year will be the third year for the publication of the "Cedrus," it being started in the year 1915 , the aim being to continue it throughout the succeeding years.

Previous to the year 1915 there were three other annuals issued by the students of the college. They were "The Imago," 1917, "Memorabilia," 1903, and the "Gavelyte," 1911. We sincerely hope that "The Cedrus" now having been well started will be able to continue through time immemorial.

\section{"The Catalogue"}

$\mathrm{I}$ $\mathrm{N}$ this publication is outlined clearly the entire work offered by Cedarville College-The Preparatory Department, The Main College Department, The Seminary, and The Summer School. This publication is very useful and a great aid to prospective students. 


\section{9

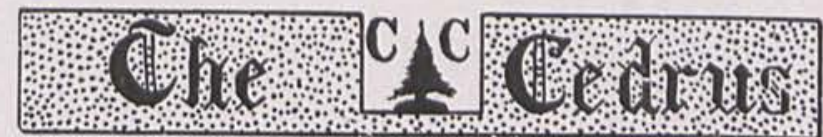 \\ 17}

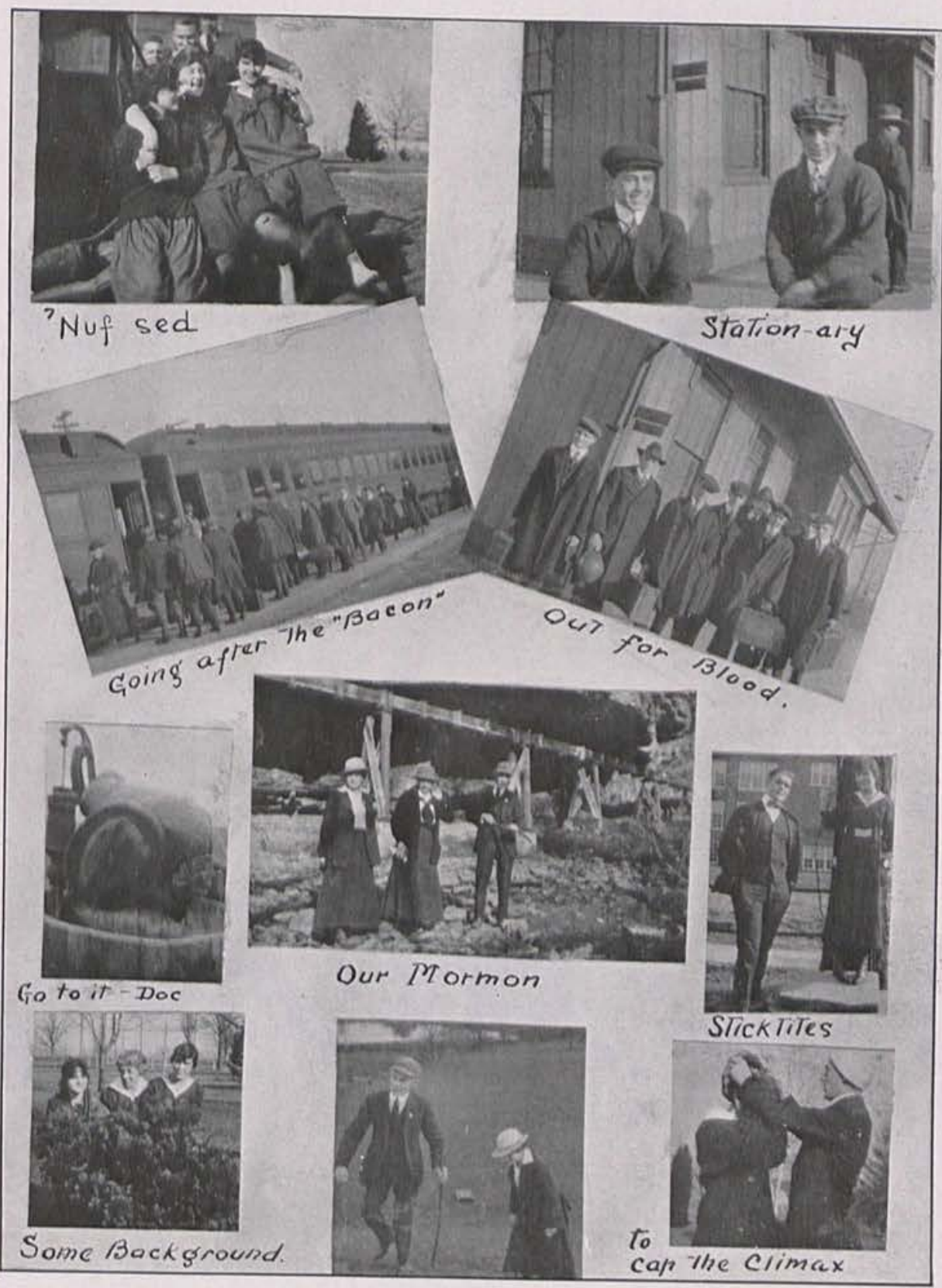




\section{9}

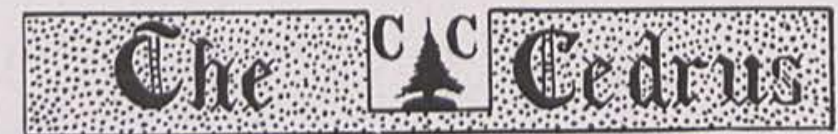

17
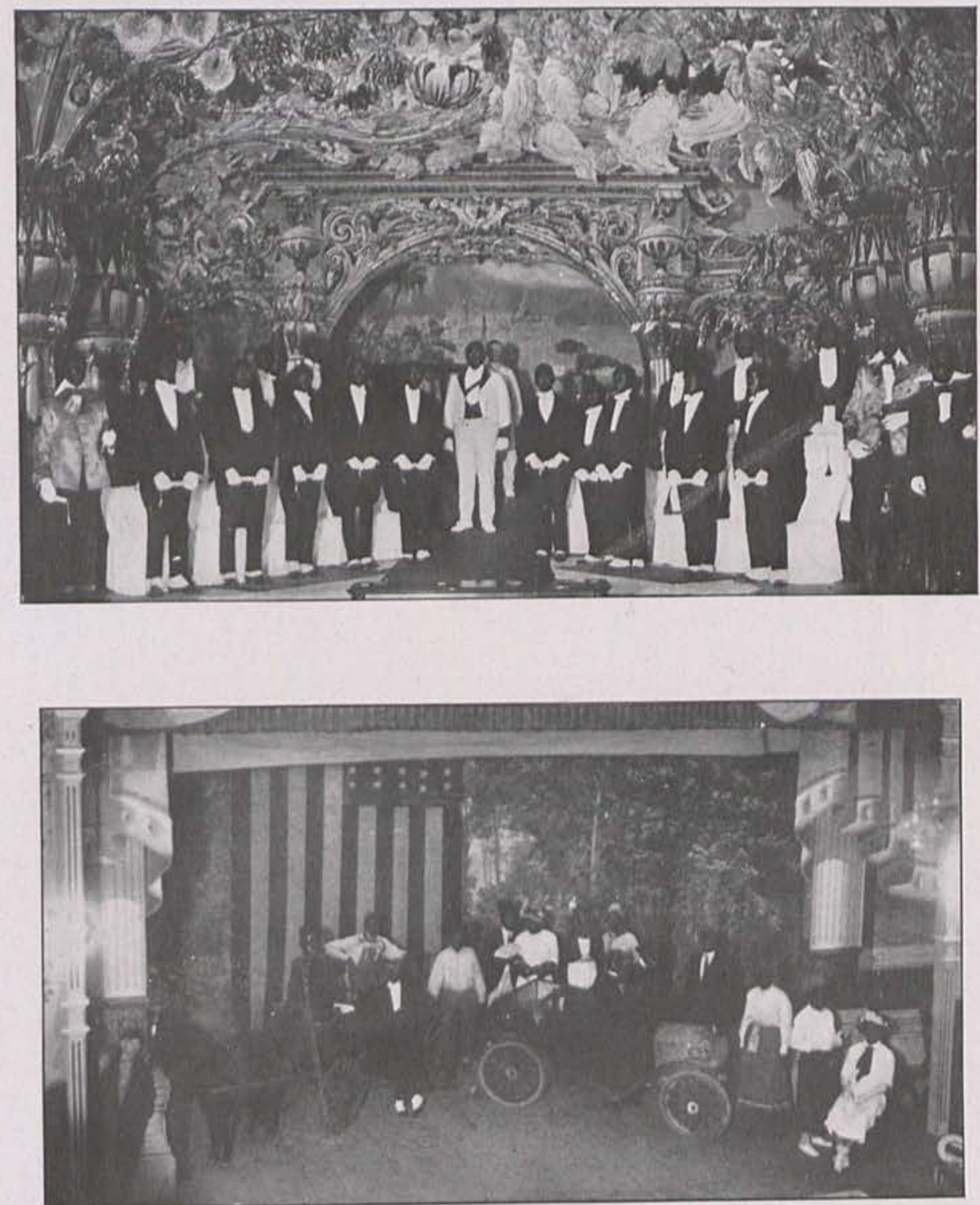

\section{Boys' Minstrel Club}

Cedarville can look with pride upon the minstrel club that represented her the past year. Through the fine leadership of Mr. G. F. Seigler, this club gave one of the best Minstrel Revues that Cedarville has ever witnessed. Firm in their determination to make the Revue a success, the boys worked hard all winter practicing twice a week, in order that they might be able to give an entertaiment of real classical music. 


\section{9

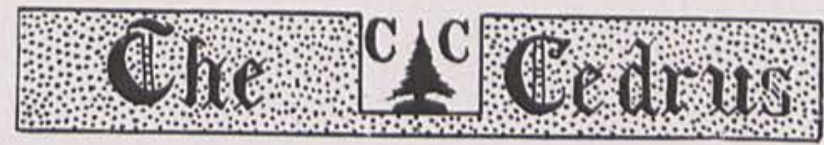 \\ 17}

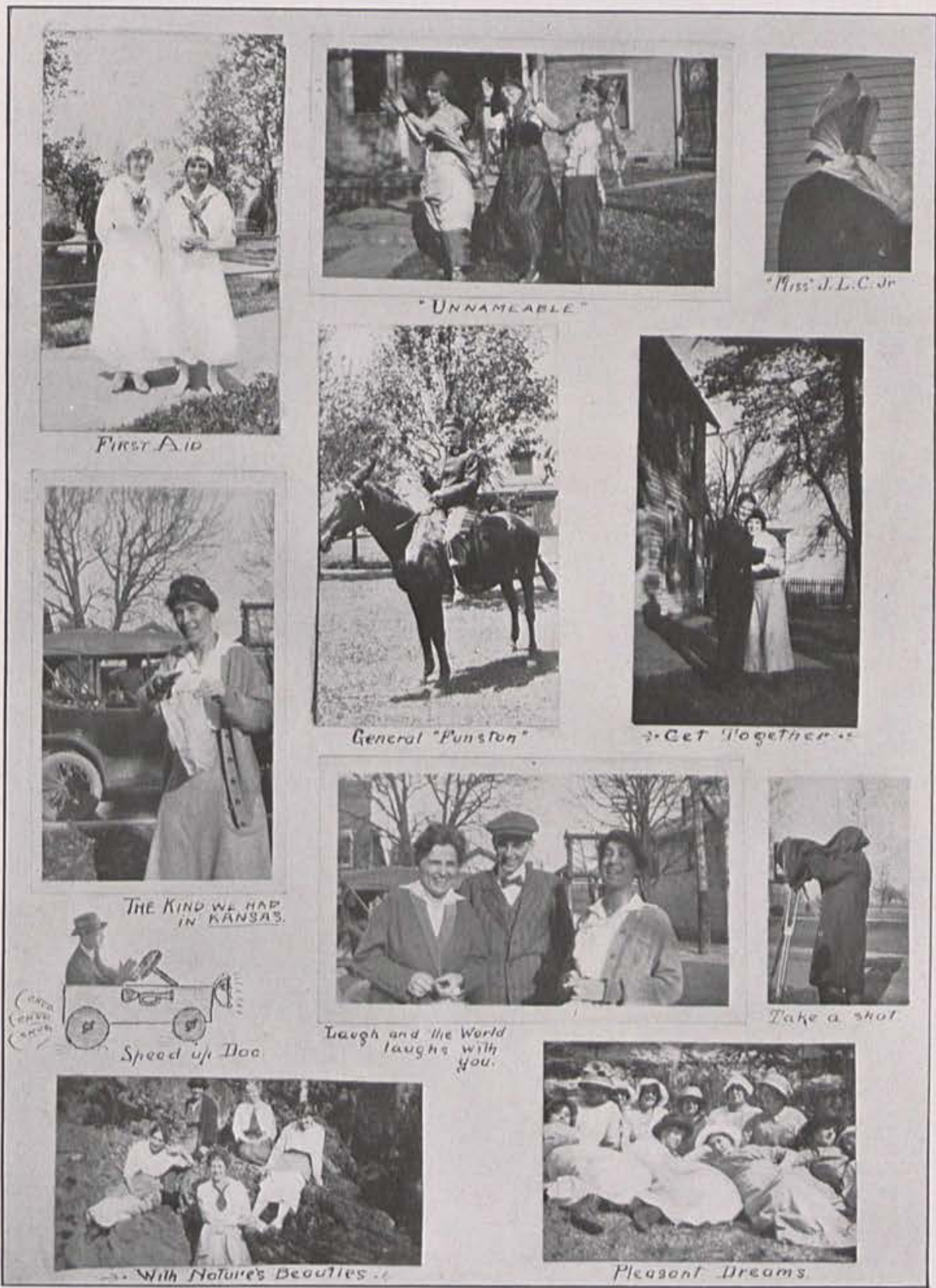




\section{9}

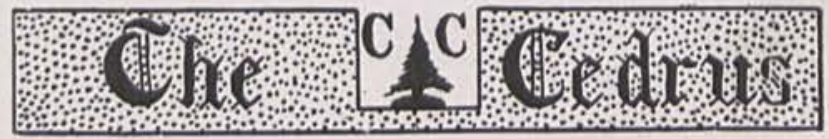

17

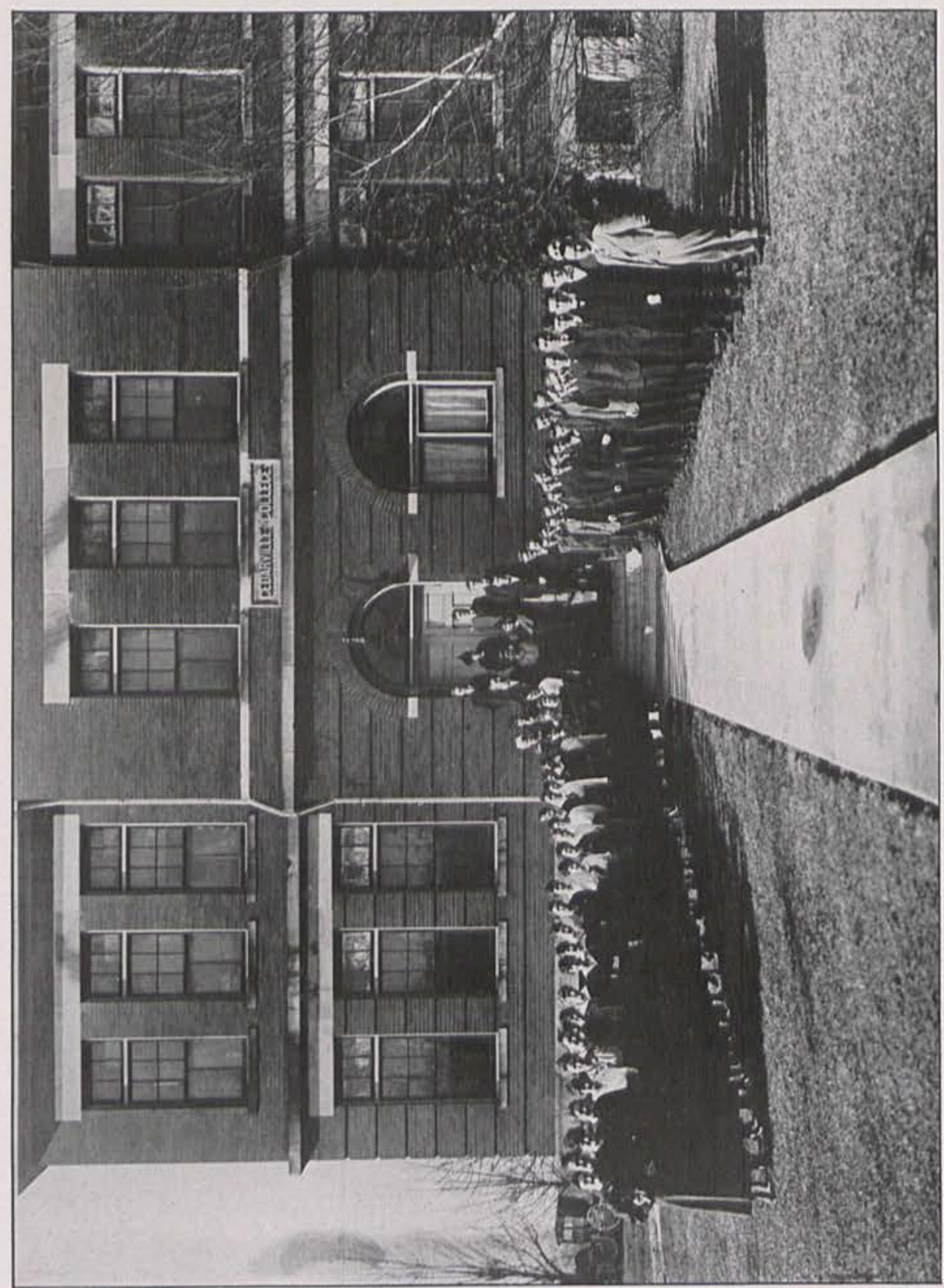




\section{Che CA Cadrus 17}

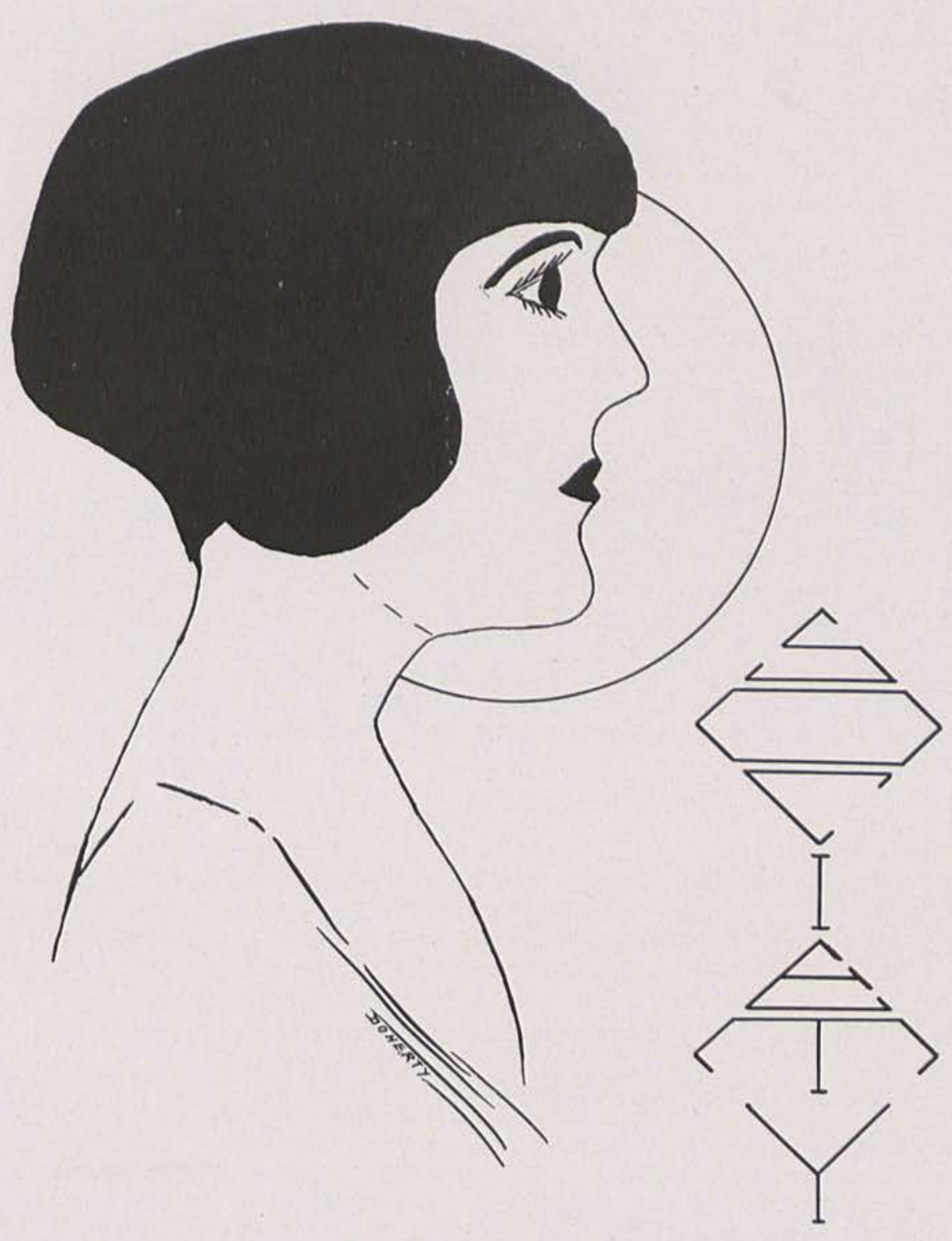




\section{9}

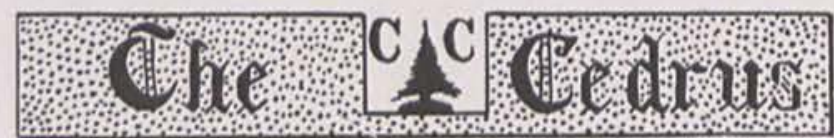

\section{Christian Endeavor Reception}

$\mathrm{O}$

$\mathrm{NE}$ of the most enjoyable events of the college year was the reception given by the Reformed Presbyterian Christian Endeavorers in honor of the new students. Games of various kinds were played, and then the students were invited to the dining room where ice cream, cake, and cocoa were served. At 10:30 the crowd departed with an expression of good will and thanks to their kind entertainers.

These Christian young people take a great interest in the welfare of the college students.

\section{Dr. and Mrs. McChesney Entertain}

On Mar. 22, the students were royally entertained at the home of Dr. and Mrs, MeChesney. After a royal welcome we mingled together laughing and chatting for a time and then were invited to the dining room where we were served in buffet style. The remainder of the evening was spent in playing games and in guessing contests, etc.

We can truly say that Dr, and Mrs. McChesney have won the heart of every student in C. C. by their cordial, unfailing sympathy and interest.

" $\mathrm{O}, \mathrm{Mc}$ Chesney is the dearest ever

And his heart's right here!"

\section{Y. W. and Y. M. C. A. Social}

Instead of holding our annual Y. M. and Y. W. C. A. receptions separately as in former years, it was decided to have a joint informal reception for the new students. So a hay-ride to the Anderson home five miles out in the country, was planned.

It was an ideal evening, and we enjoyed the ride immensely. Upon our arrival we enjoyed ourselves socially for a time and then adjourned to a monstrous bonfire prepared by our host in the orchard. We proceeded to roast wieners and marshmallows, accompanied of course by buns, pickles, a great basketful of luscious peaches and other articles too numerous to mention. At a late hour we departed on our "jolty" homeward journey, feeling that the friendships begun that night would never be broken.

\section{Hallowe'en Party}

On Oct. 27 the students assembled at the "Gym." for the annual Hallowe'en party. It was the boys' turn to act as hosts this year, and it can be truthfully said that this event eclipsed all others of previous years. The room was decorated with Jack O'Lanterns and beautiful autumn leaves. By request the guests came in disguise and the gym rang with laughter as the students recognized one another in the ludicrous costumes. Later the disguises were removed and the crowd was seated. Then came the memorable "feed," which we haven't forgotten yet, everything from chicken and biscuits to pie and jello. After supper we listened to ghost stories, performed laughable stunts, and had our fortunes told. At ten o'clock we departed voting the boys delightful hosts. 


\section{9}

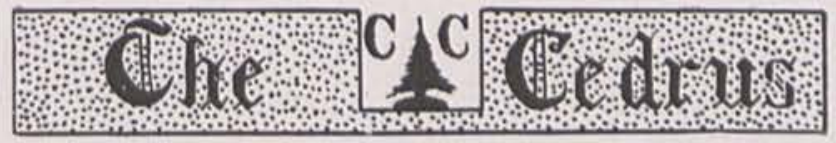

17

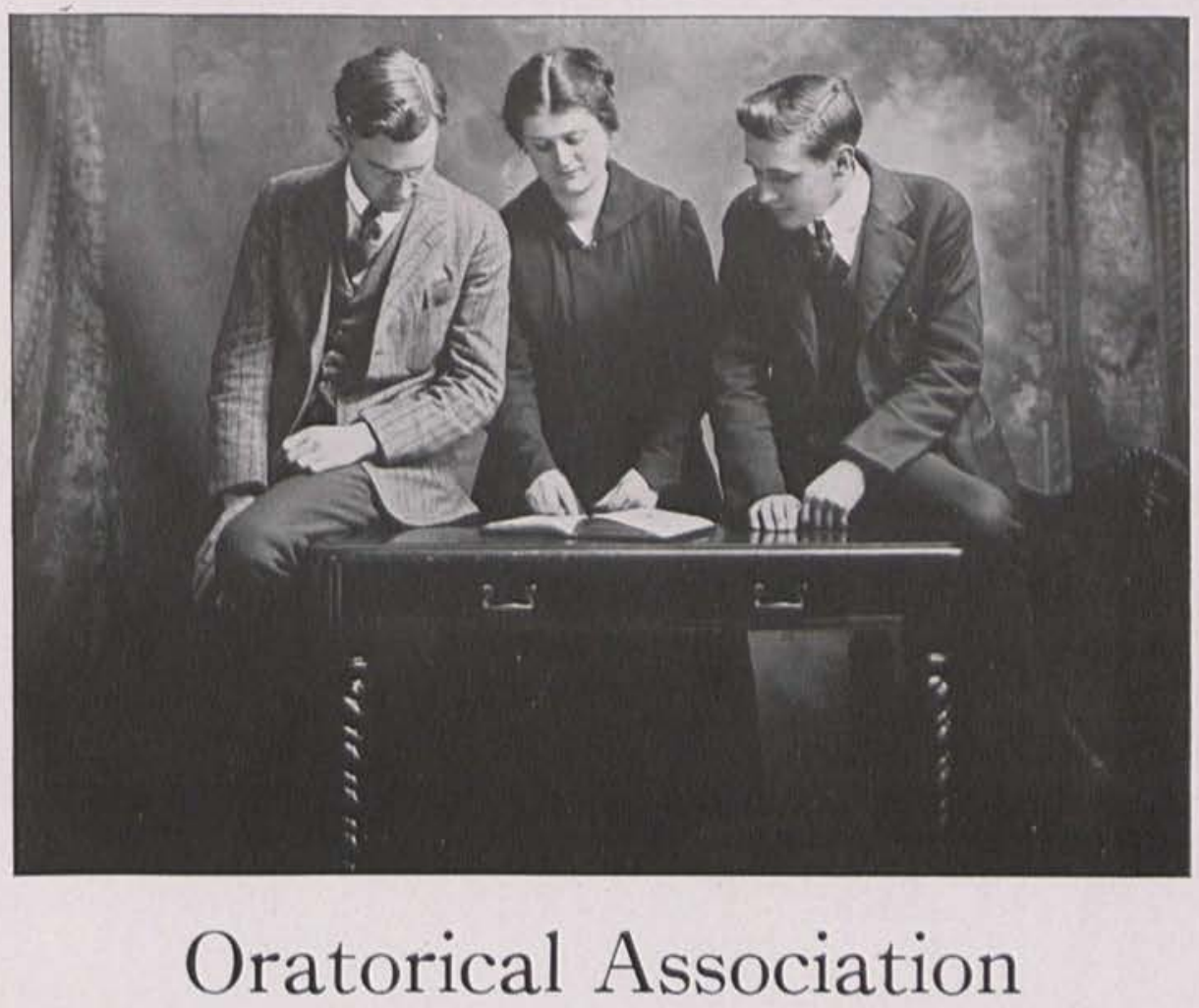

$\mathrm{O}$

NE of the greatest benefits to be derived from a college education is that obtained in public speaking. In Cedarville College the Oratorical Association has done much to fit the young men and women who have been enrolled in its membership to speak in public.

Cedarville College is a member of the Ohio Inter-Collegiate Oratorical Association, which, in turn, is a division of the Interstate Association, including ten of the leading states of the Middle West. A preliminary oratorical contest is held during the first semester of each year, the winner representing the College in the State Contest. The winner of the latter represents the State of Ohio in the Interstate Contest. This Association with which the College is connected is the oldest and largest oratorical association in the United States, many of the eminent statesmen of the day having received their early training in its contests. 


\section{Help Yourself}

TO THE FRESHIES

To this good advice, little Freshies take heed,

These rules of conduct, wee kiddie's will need

Be seen and not heard, my lecture's begun,

Before I have finished, I will not have done.

Never skip to your classes, walk ever you must,

Jumping rope bores the Seniors, and raises the dust.

Wash your hands and your faces, 'fore coming to school,

Don't forget book or pencil, eraser or rule.

Leave your dollies, and marbles, and building blocks home.

Lest a sly thievish Soph'more will ask for their loan.

Your little milk bottles, you may have if you wish.

Be careful to leave them where the milk will keep fresh.

Be polite and respectful when Seniors you see.

Be good little Snookums, as Freshies should be.

$$
\text { TO THE SOPHS. }
$$

Now my friends, the Sophs; it will be your turn,

You are still young enough from your elders to learn.

Don't think because you are one vear old

There is nothing at all you can't be told

Don't swagger or strut, $O$ Sophomore.

Or don't be bashful and look at the floor.

Don't tell teachers how class should be run,

Remember your college life is only begun.

Don't romp with the Freshies, such things will not do.

With infantile pranks and pastimes you're thru.

With the Seniors or Juniors don't follow along:

You're not wise enough to mix with that throng.

Just stick to your knitting and work every day

And all good things will be coming your way.

\section{TO THE JUNIORS}

You Juniors all think from advice you are free.

Just forget that idea and listen to me.

We grant, of learning, you've got a great much.

But still there are a few points which I might touch.

Don't ape the big Seniors in gesture or way:

Be original in all you do and say.

Don't be a bluffer, whatever you are.

A bone-head or loafer is better by far.

Don't dress in apparel extreme or absurd.

Your clothes may be looked at, but they're not to be heard.

Don't try to flirt and think you are bold.

"Tis best to be modest, by our parents we're told.

See that your work is ever well done;

It's the surest path that leads to Room I.

\section{TO THE SENIORS}

To you, ayed friends, now must I talk.

At lectures or rules you generally balk.

A Senior is mighty and thinks he is it,

But even at that I will say just a bit.

Don't laugh at the Freshies and call them all slow;

You'll be one next year, if to Oxford you go.

Don't think you are Master of all you survey,

It's only a snob, who will act in that way.

Don't lord o'er the younger boys and the girls.

Twas not long ago, you lisped and wore curls.

Don't look so serious, or talk so low;

Such beastly habits, upon one grow.

Don't loaf all the time, now your course is most run,

But be able to say, "My task is well done." 


\section{9}

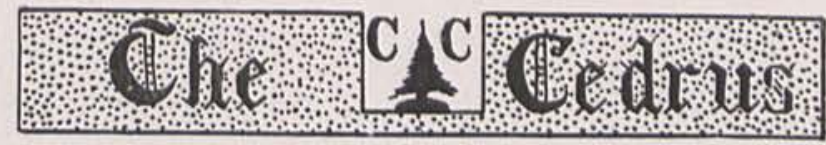

17
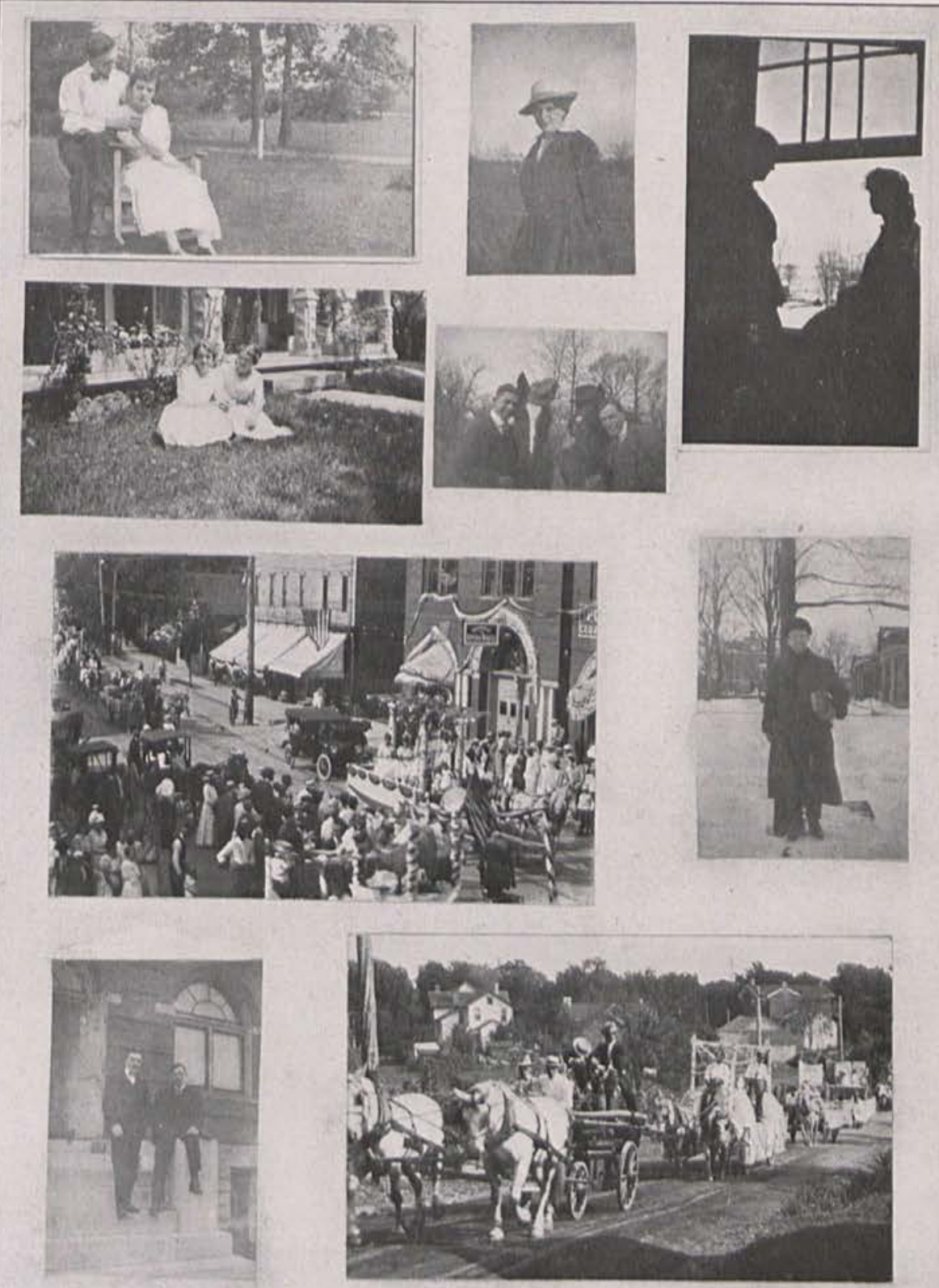


\section{9}

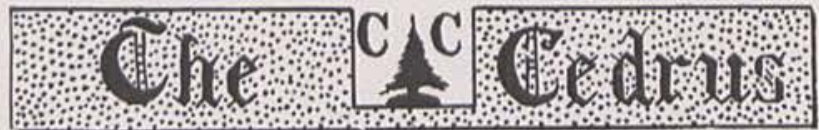

\section{Last Will and Testament of Class of 1917}

$\mathrm{W}$

E the members of the Senior Class of 1917, being of sound mind and memory, and realizing that the time we shall abide in this school is short, wish to bestow upon our heirs, the Faculty, and the lower classmen, our last school-day effects in a manner and form stated herein.

To the Faculty we give and bequeath our loyalty and gratitude for the instruction which they have so conscientiously given us.

To the Juniors, we do give and bequeath our rightful sense of superiority and dignity.

To the Sophomore Class, we do give and bequeath our esteemed sense of propriety and do admonish the said class to conform to the standard maintained by legator.

To the Freshmen, we do give and bequeath our accustomed ease and knowledge of all school affairs, to be limited by no other class but to be emulated by all.

\section{Personal Bequests}

I, Florence Somers do give and bequeath fifty pounds of my avoirdupois to Olive Northup.

I, John Collins do give and bequeath my basket-ball suit to Paul Duncan.

I, Mary Chesnut, do give and bequeath my winter hat to Helen Oglesbee.

I, Mabel Stormont do give and bequeath my French grades to my brother Meryl.

I, David Doherty, do give and bequeath my artistic ability and good looks to Norman Foster. Dean.

I, Ruth Ramsay do give and bequeath my loquacious ability to Elizabeth

I, Anna Collins, do give and bequeath my "gift of gab" to Oliver Cornwell.

I, Robert Hutchinson, do give and bequeath my seminary duties to William Anderson.

I, Lorena Taylor, do give and bequeath my knowledge of Kentucky and Kansas to Prof. F. A. Jurkat.

We, the Senior Class, do give and bequeath our sincere sympathy to those people who have been so unfortunate as not to have known the class of 1917 .

In testimony whereof, we the members of the Class of 1917 , hereunto do set our hand in seal and publish and decree this to be our last will and testament in the presence of witnesses, the third day of March one thousand nine hundred and seventeen.

Signed, sealed, declared, and published in the 1917 Cedrus by the said Senior Class for their last will and testament. 


\section{Sad, but True}

Now don't get excited if you should hear shrieks.

Wallace Anderson's grave is long and thin.

His wife killed him with a rolling pin.

Poor Rebecea Marsh, the teacher's pet!

We hope their spirits haven't met.

Louisa Greer's tomb, you see.

She died of grief o'er a sevent-ee.

Morton Creswell died this spring,

And now with the angels he will sing.

Roy Clark's body here should be,

But he was drowned in the deep blue sea.

Ellen Tarbox lies here-a sweet little child,

Whose incessant giggling 'most drove us wild.

Margaret Elder lies buried here.

We miss her, too, for she was a dear.

Another one has gone to rest,

And I believe his name was Test.

Helen Bradfute lies in this narrow space.

She was graceful of form and fair of face.

Over this grave we'll all shed a tear,

For sweet Millie Parker lies buried here.

Marguerite Gilkey is now at rest.

They say she collapsed from a Chemistry test.

Here lies the most bashful boy ever seen.

He went by the name of Leslie Dean.

Reba Harbison lies under this tree.

She was as quiet as quiet could be.

Helen Creswell, too, has gone away.

Her horse ran off with her one day.

Miss Schneder, the teacher, departed - alas!

She couldn't survive that Rhetoric Class.

\section{Songs Popular at C. C.}

The Little old Ford rambled right along-Janet.

Rebecea of Sunny-brook Farm-Foster.

I want a girl-Turnbull.

Kiss me Good-night-McClure.

Pick-a-wick-Cora Cavender.

I'm glad I'm married-Hutchinson.

I wonder where my loving man has gone-Irene.

Since I fell in love with Mary-Ralph Elder.

Let's all go 'round to Mary Ann's- "Ollie."

On the arm of the old Arm-chair-George.

I'd rather two-step than waltz, Bill-Helen 0 .

When you and I were young, Maggie-Duncan.

My Eileen-Morton.

Bring back my Bonnie to me-Ruth $R$.

'liza, my 'liza- "Bush"

Helen-Clark.

My old Kentucky Home-Miss Taylor. 


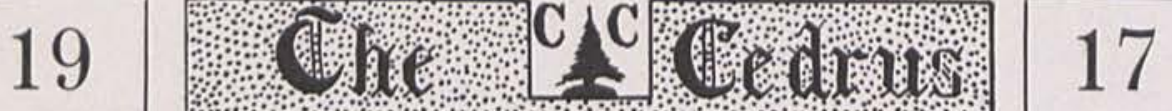

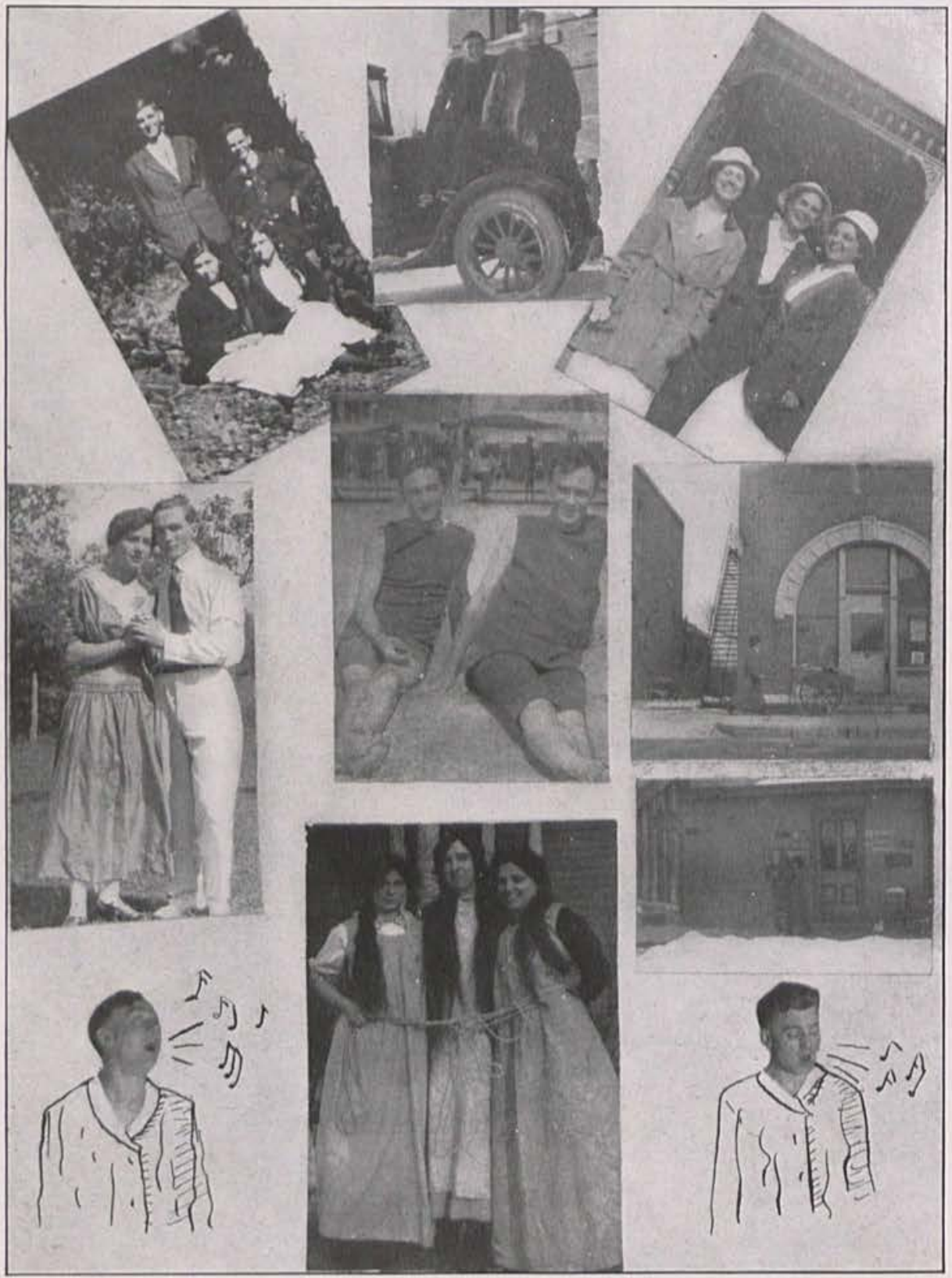




\section{9}

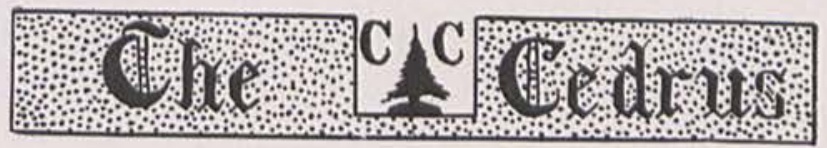

\section{"Scraps"}

\section{COLLEGE MAGAZINES}

Everybody's..........Anna Collins Woman's Home Campanion .......

................ Bob. Coleman

McClure's.............. Mary Bird

Pictorial Review...... Pauline Smith

Scientific American.... Allen Turnbull
Christian Union Herald. Ralph Elder Literary Digest......... Prof. Jurkat The Housewife...... Janet McCellan Good Housekeeping.... Irene Wright The Etude..........Helen Oglesbee

\section{BY THEIR WORDS YE SHALL KNOW THEM}

Prof. Jurkat-Have you ever read this?

Prof. Allen-Keep on, you're on the right track.

Dr. McChesney-Well-In the final analysis we have -

Prof. Schneder-Isn't that juicy?
Prof. Taylor-Down in Kentucky-

Prof. Wright-The statistics go to prove that-

Prof. Creswell-Now you know that isn't true.

Prof. Parker-Now Somebody is laying down on the job.

\section{AND BY THEIR ACTIONS YE SHALL KNOW THEM}

Prof. Jurkat-Eating Peanuts.

Prof. Allen-Ruffling his curls.

Dr. McChesney - Using gestures.

Prof. Schneder-The Highland Fling.
Prof. Creswell-Admiring her ring finger.

Prof. Taylor-Being pleasant.

Prof. Wright - Smacking his lips.

Prof. Parker-Giving tests.

\section{COLLEGE CHAMPIONS}

Allen Turnbull-Chemist.

Helen Bradfute Short lady.

David Doherty - Artist.

Helen Creswell-Red head.

Helen Oglesbee-Musician.

Robert Hutchinson-Newlywed.

George Smith-Hot-air merchant.

James Chesnut-Nut.
Oliver Cornwell-Short man.

William Anderson-Our Beauty.

Paul Elwood-Question Mark.

Norman Foster-Lady's man.

Janet MeClellan-Grind.

Paul Duncan-Y. M. C. A. politician.

Charles McClure-Accident.

John Collins-Cartoonist.

\section{YOU ALWAYS KNOW}

Bill Collins by his feet.

Paul Duncan by his walk.

Anna Collins by her noise.

Irene Wright by her powder.
Lorena Taylor by her laugh.

Millie Parker by her blush.

Marguerite Gilkey by her smile.

Rebecca Marsh by her bashfulness. 


\section{9

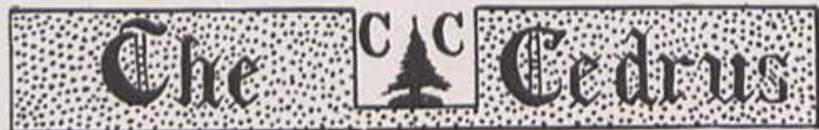 \\ 17}
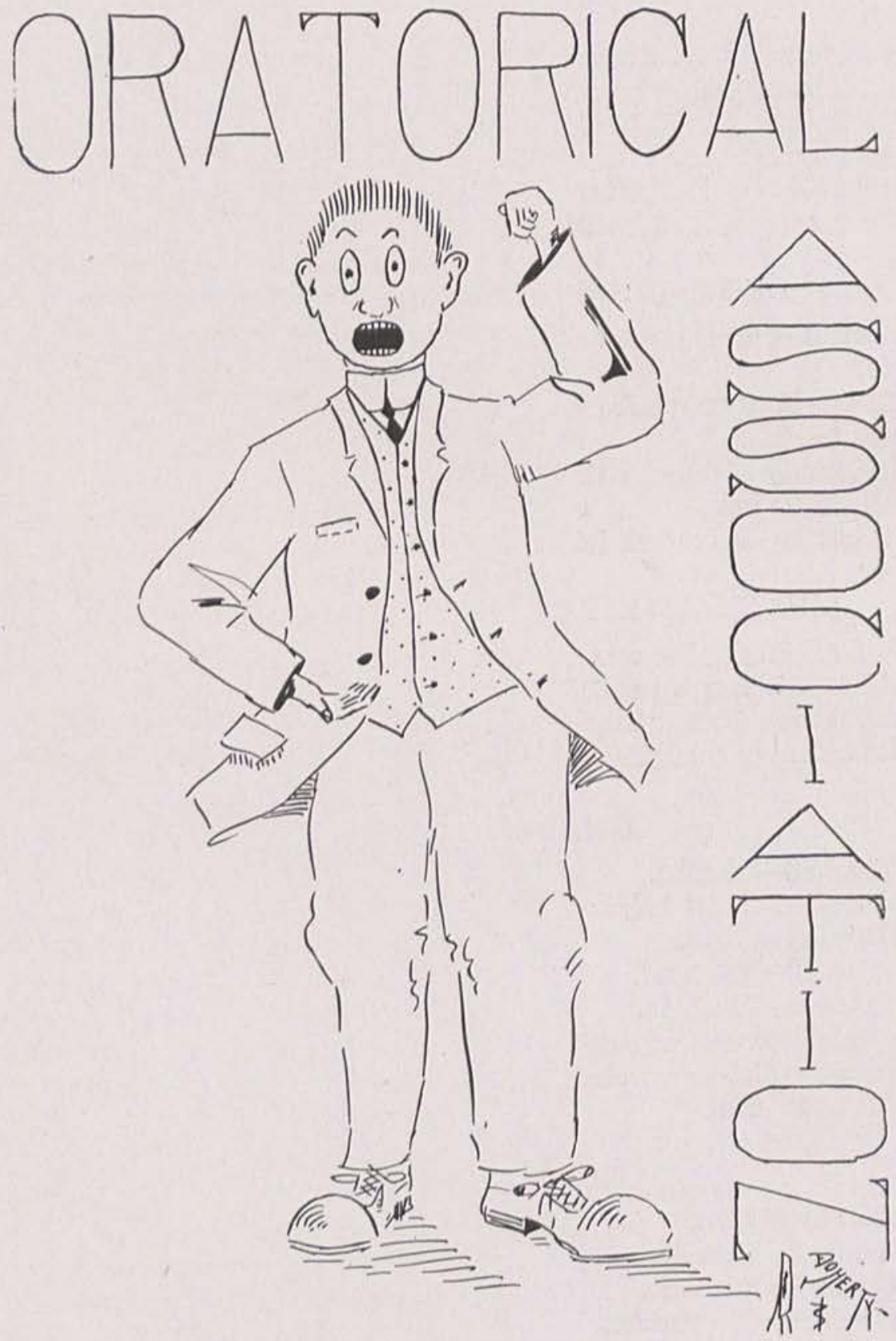


\section{9}
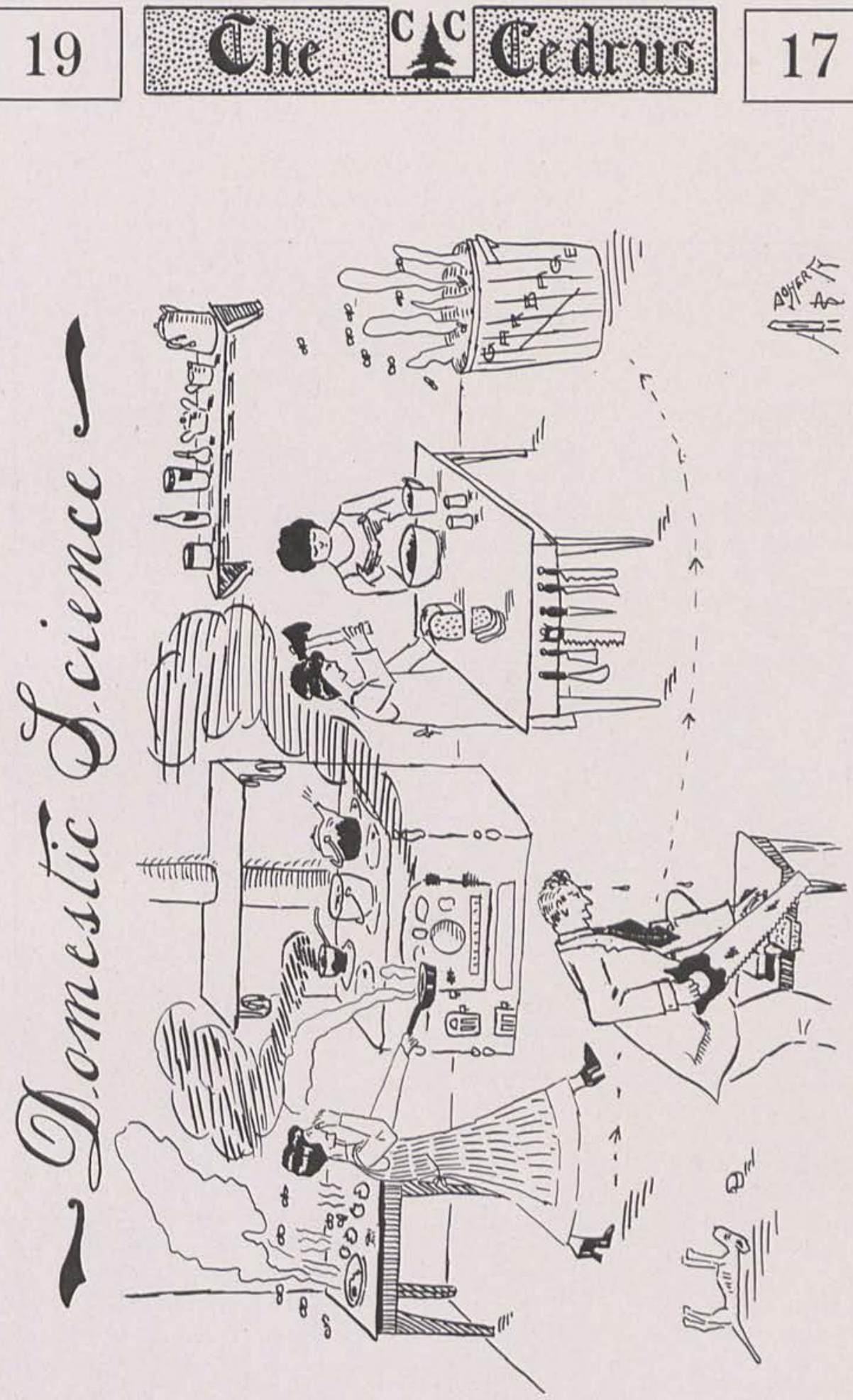


\section{9}

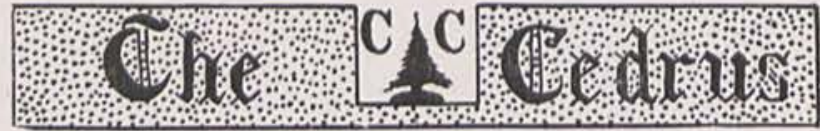

17

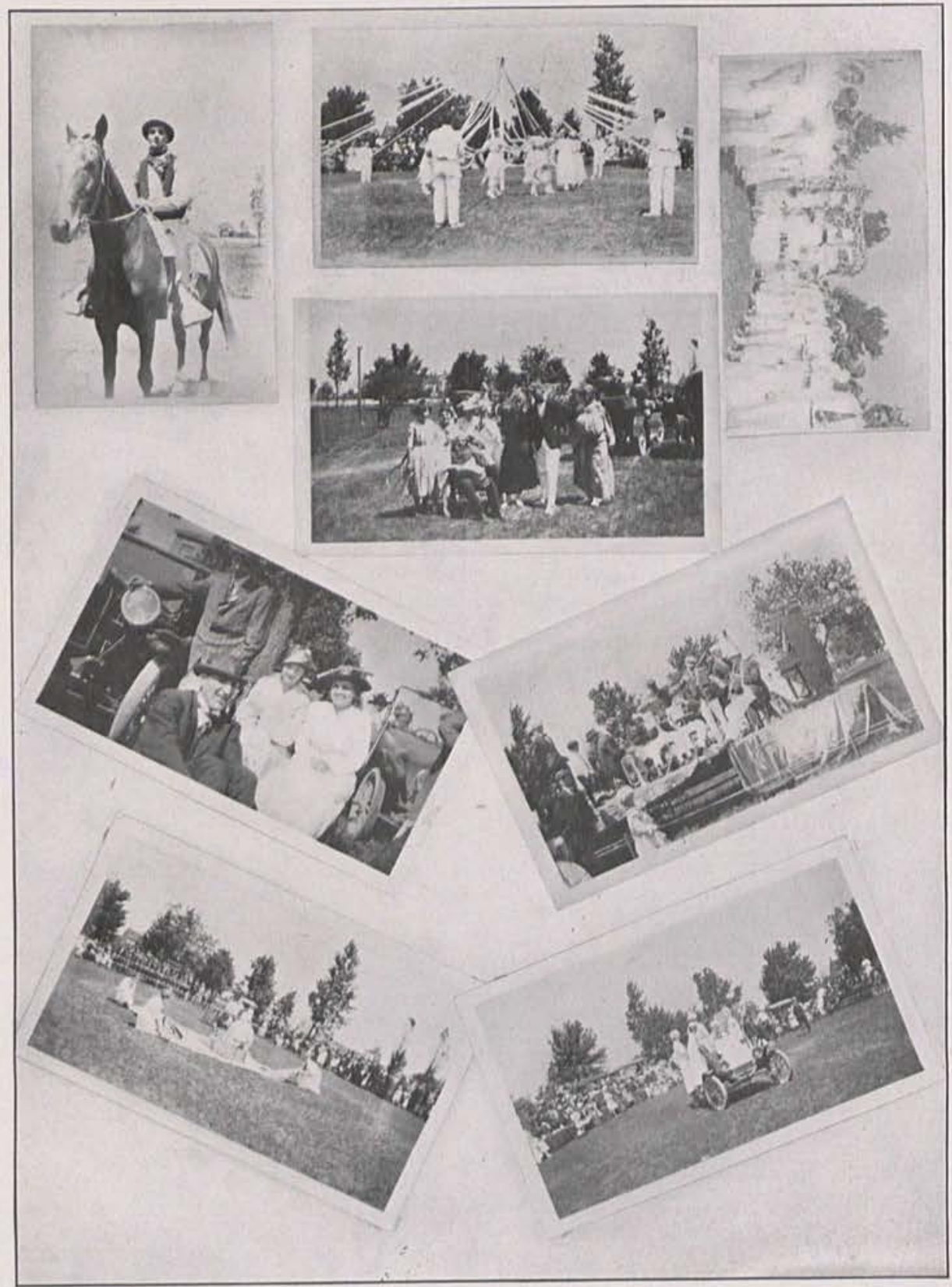




\section{9}

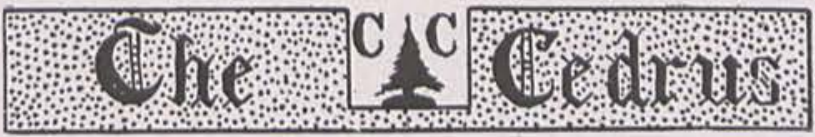

\section{"Log Book"}

OстовеR 1. Several embryo debaters make first attempts in the forensic line before the debating class.

Остовев 11. Florence Somers elected editor-in-chief of Cedrus Staff. William Anderson business manager. Prof. Allen comes to the lamentable conclusion that his debating class can not yet be put on the market as a finished product.

Остовев 13. Freshmen by superhuman effort inject enough pep into their-semi-dormant-selves to have a spread at the rural domain of "President Creswell."

Остовег 17. First meeting of 1917 Cedrus Staff. Plans laid for making it bigger, broader and grander. Amen!

OCтовER 18. Editor in-chief gives us the information that we have a chance to carve our "monikers" in the halls of literary fame. In other words a 1917 Cedrus offered for the best short story and one for the best poem handed in for the Cedrus.

Ocтовеr 20. 13 innocent Freshmen and Sophs. are led like lambs to the slaughter. Occasion:-1st. Algebra test. Place:-The math shark's paradise. Preceptor:- "That man Parker."

OстовеR 24. Hawaiians at Opera House in first number of Lecture Course. Guitar player makes big hit. Girls anxious to learn the "Hoola-Hoola."

Octoser 25. Two C. C. Alumni, Mildred Corry and Ernest Foster begin life in double harness. Dr. Foster helps them to get hitched up.

Octoвer 27. Boys entertain the girls at annual Hallowe'en feed. Faculty members tell shivery ghost stories; Prof. Allen: "I am not anybody's husband, don't want to be anybody's husband etc.

OстовеR 28. The morning after the night before, 5 or 6 recovered sufficiently from the night before to "clean up the gym" and in so doing get the benefit of left-over pies, oysters etc.

Three roomers at the Townsley-Lodge make pumpkin pies with milk seasoned with oyster shells by some unknown worker of iniquity. The milk was "left-over" from Hallowe'en.

ОстовеR 30. Chapel prayer-meeting for coming evangelistic meetings. Geo. Smith makes known to the Apologetics class his knowledge of catechism.

Остовеr 31. Dr. James Foster of New Wilmington Pa. gave some very timely advice in a chapel address.

November 1. Chapel stacked. "Of all sad words of tongue or pen, the saddest are these, she's stacked again." Dr. McChesney makes inquiries: John Wright and James Chesnut very innocent, giving proof of having retired early night before, but said nothing about getting out of room via ladder.

Novesmer 2. Second number of Lecture Course. Japanese dancer and hoseband Taki. George Smith forgets to make date. Rabbit feed by select few at Ann Collins.'

November 3. Several "Nimrods" make life unsafe for the cotton tails.

November 6. Straw vote in chapel, Hughes wins out, but Benson gives him hard chase. Ballot box stuffed about 20 more votes than students.

November 7. Much interest shown in election. Dean and Turnbull tossed in blanket at expense of blanket. Surprise on Wallace Anderson.

November 8. Election returns show very close race for presidency. Cox elected govenor. Presidency still in doubt.

November 9. Wilson elected. Quaker inspectors in chapel. Rain all day, dry 'enuf' inside.

November 10. Mrs. Drummond, state sec, W. C. T. U. speaks in chapel. Y. W. holds sewing bee in library during afternoon and evening. This particular species of bee is noted for its "buzzing" ability. 


\section{9}

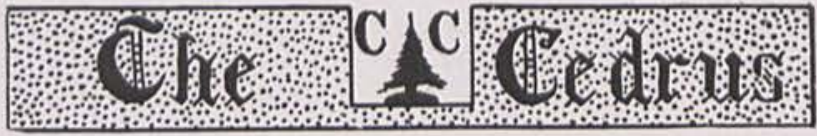

November 18. Rev. Koontz of S. Charleston gives talk in chapel on Alaska and his experiences as a missionary,

November 14. Bids submitted for printing of 1917 Cedrus. Mr. Evans lectures in Opera House????

November 15. State Sec. of Y. M. C. A. Mr Bjoelke visits Y. M. makes big hit in chapel. For further information see business manager of this "sheet." Mr. Evans actually arrives and in lecture on "What America needs" he takes the conceit out of us and shows what America does need.

Noveamber 16. Prayer-meeting in chapel in behalf of evangelistic services. Dr. Atkinson opens three weeks' evangelistic services at Opera House.

Novemben 17. "Newly-weds." Doc. Lloyd '15 and Miss Dallas are belled. Dire threats of being "canned" causes several perfectly good R. P's to quake in their boots.

November 21. Dr. Atkinson leads chapel service with inspiring song service. He presents 100 new song books for chapel use.

November 22. Basket Ball starts for girls and boys teams. Good prospects for both. "Tom" Kennon elected captain of boy's team.

November 29. Normal class pays visit to Ross Twp. schools thru' mud "up to the neck". Mr. Sullenberger sings in chapel.

November 24. Mr. McIntyre visits chapel and organizes I. P. A. Association. H. S. and college night at evangelistic meetings.

November 27. Carl Duncan, an old student of 1912-14, here from Darlington, Pa.

November 29. Dr. MeChesney gives Thanksgiving address in chapel. P. H. Creswell comes in during chapel.

November 30. Thanksgiving vacation. Few of the students go home to feast on turkey.

Decemrer 4. Fourth number of the Lecture course. Reading by Miss Bewly. Some rain, especially down at the station. For particulars ask Senior Class Pres. "et cetera" of the Sophomores.

Decramer 5. Everbody back from Thanksgiving with turkey and pumpkin pie in their eye. We decide to remain in State Oratorical Association.

December 6. Boy's B. B. team putting on finishing touches for first game Fri. night. Dr. Chesnut pays his first visit to practice.

December 7. Boys divide proceeds of Hallowe'en feed, (a 35c box of candy). Chapel piano develops sudden wheezing in inward parts and Prof. Wright pulls a great sheet of paper therefrom.

December 8. Mr.McIntyre from Xenia Sem. here helping raise funds to send delegates to Lexington convention. B. B, season opens with 52-20 victory over Springfield Y. M. C. A.

Decesrber 11. Nine rahs for Girl's and Boy's B. B. team. "Don't forget to pay your tuition."

December 12. Rev. McLennan gives a great talk in chapel. Several students journey to Yellow Springs to see Antioch defeat Wittenberg in B. B.

Decesmer 14. Pep meeting for B. B. game Fri. night with Bliss College. Sophomore spread at Creswells.

December 15. College closes on account of scarlet-fever. B. B. game canceled. Vacation begins.

JANUARY 1. New Years resolutions made only to be broken next day.

JANUARY 2. Students return.

Janeary 3. Prof. Rob. Harper talks in chapel. Cam Ross and mustache appear in chapel. He sings a solo.

JANUARY 5. Both teams go to Wilmington. Score? Nuf ced.

Jandary 7. Geo. Smith elected cheer leader.

JANUARY 10. Dr. McChesney announces that since June 1916, the endowment fund has been increased by $\$ 7000$. 


\section{9}

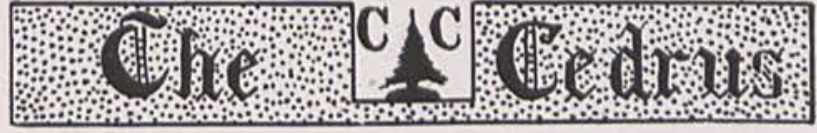

JANUARY 11. Oratorical contest. George Smith proclaimed orator of the day. MeClure second place.

JANUARY 12. Elwood masquerades and delivers address on Discovery of America.

Jandary 13. Lecture at Opera House on "Hard Knocks," by Ralph Parlette.

JANUARY 15. New schedule for second semester on bulletin board.

JANUARY 16. Doherty takes short cut down stairs at expense of his trousers.

JANUARY 18. Joint meeting of literary societies. Much enthusiasm. Work planned for New Year.

JANUARY 19. Girls lose fast game at Middletown.

JANUARY 20. Second team wins fast game over Antioch second team. Score 14-7. First team play rings around Bethel $61-31$.

JANUARY 23. Miss Schneder gives talk in chapel on Japan. She gives us something to think about; How would Prof. Jurkat look drawing a jinrikisha?

Janesry 25. Boys B. B. team leaves for Ashland and Muskingum. Win at Ashland 82-21. Lose at Muskingum 51-40.

February 1. Wheeler takes group pictures at college for Cedrus.

February 2. Prof. Allen appoints himself detective to find alarm clock in piano in his room.

February 3. Tests begin.

Femroary 4. Final exams. Girls play Plattsburg. Victory 24-13.

February 5. Middletown girls arrive. We don't care to mention the B. B. score. Boys get revenge on Wilmington 36-24.

February 7. Mr. Burge, a missionary, gives address in chapel.

February 8. Rev. McCauley delivers address in chapel.

February 9. Second Semester well started. Ashland College cancels B. B. game with C. C.

February 12. We meet our old rivals, Antioch B. B. team, at Antioch and are defeated.

February 13. B. B. team goes to Sabina and gets short end of score.

Ferroary 14. Margaret Elder gives an interesting report before Y. W. and Y. M. C. A. on Student Volunteer Convention held at Muskingum February \&, 3, 4.

February 15. Call for volunteers!' Not to fight Germany but to assist Prof. Allen address Summer School catalogues.

February 16. Day of Prayer for colleges. Rev. Horn of Jamestown preaches excellent sermon.

Femruary 19. Ruth Ramsey elected May Queen, Ollie Cornwell elected May-pole.

February 20. Characters assigned for Cedar Day, Ollie Cornwell gets hobby-horse job.

February 21. Duncan gives his report on Student Volunteer Convention.

February 29. Washington-Lincoln Program.

February 24. Return game with Antioch at Cedarville. Much rejoicing over score $26-20$ in our favor.

February 28. Freshmen spread at Tarboxes. Sleeping quarters slightly disturbed.

Млrсн 2. B. B. game with Indiana "Mules," Victory! 42-26

March 8. Sophomore spread at Dr. Adams'. Coleman's trunk takes midnight journey.

МАrсн 9. Select six have spread at Ann Collins'. Plan for homestead.

Мавсн 12. Rev. Ernest McClellan of Belle Center visits chapel.

МАRсн 18. Robert Hutchinson elected Cedar Day orator.

Млгсн 16. B. B. team goes to Colmbus to play Mutes and receives little end of score.

March 22. Dr. and Mrs. McChesney entertain student body.

MАrсH 26. Y. M. C. A. make plans for work of coming year.

March 29. Geo. Smith represents C. C. at I. P. A. contest at Xenia. 


\title{
19
}

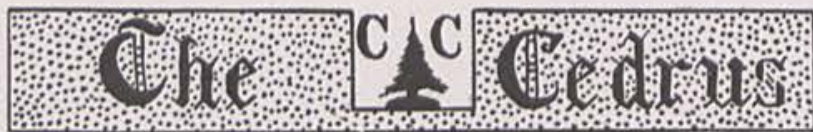

\section{Reformed Presbyterian Church}

\author{
FOREIGN MISSIONS HOME MISSIONS
}

THE Reformed Presbyterian Church looks to Cedarville College for missionaries. Miss Martha Ramsey continues to do good work in Los Angeles and the Rev. Wm. Waide in India, and both are graduates of Cedarville College.

Mr. Ralph S. Elder a talented, scholarly, and consecrated young man has offered himself to the Board of Foreign Missions for service in India. These together with Mr. R. N. Coleman, Jr., who offered himself last year, will make four missionaries from Cedarville College for our own church. The Board of Foreign Missions and the whole church will be glad to hear of others. 

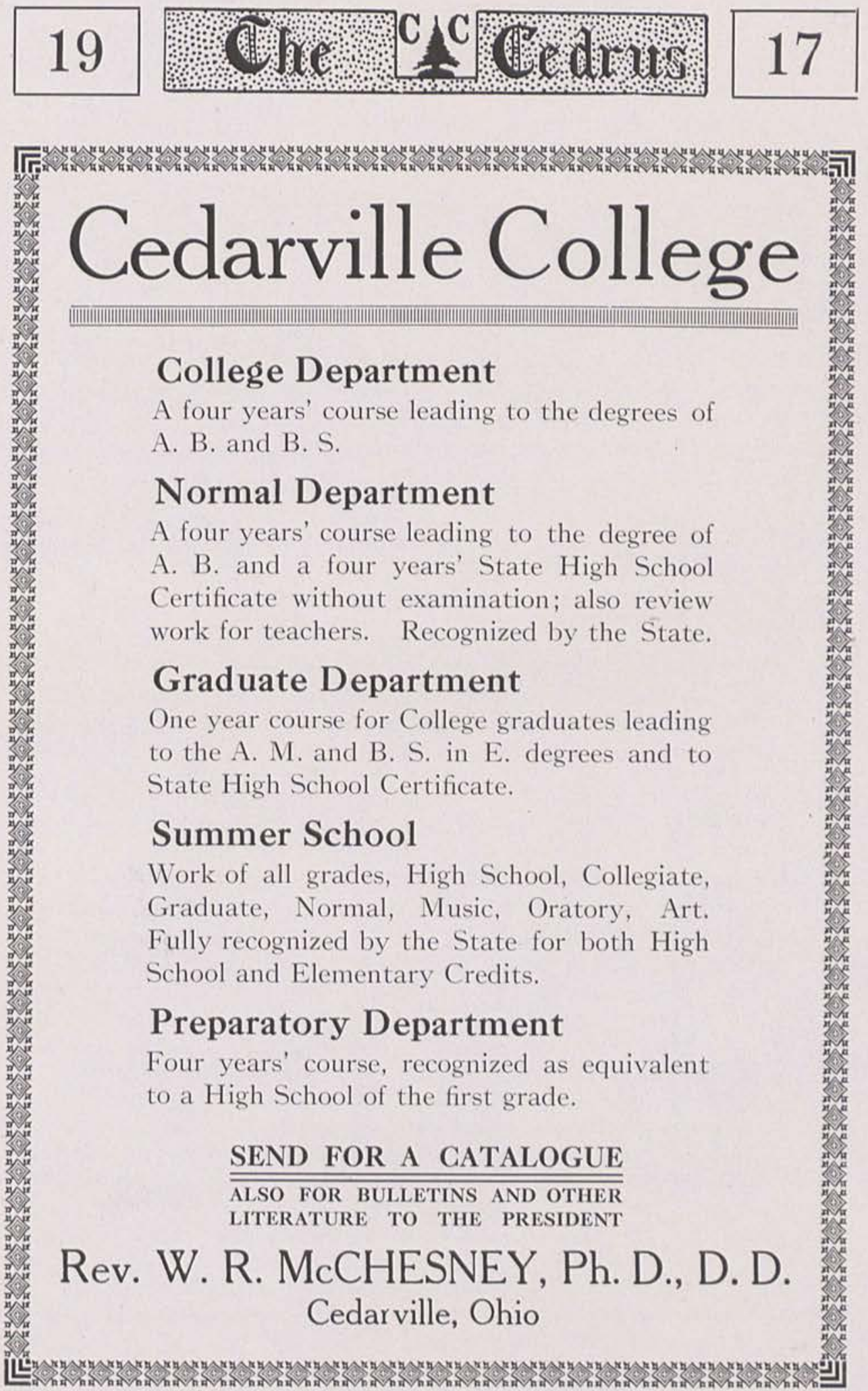


\section{9}

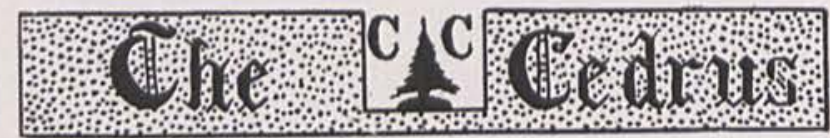

17

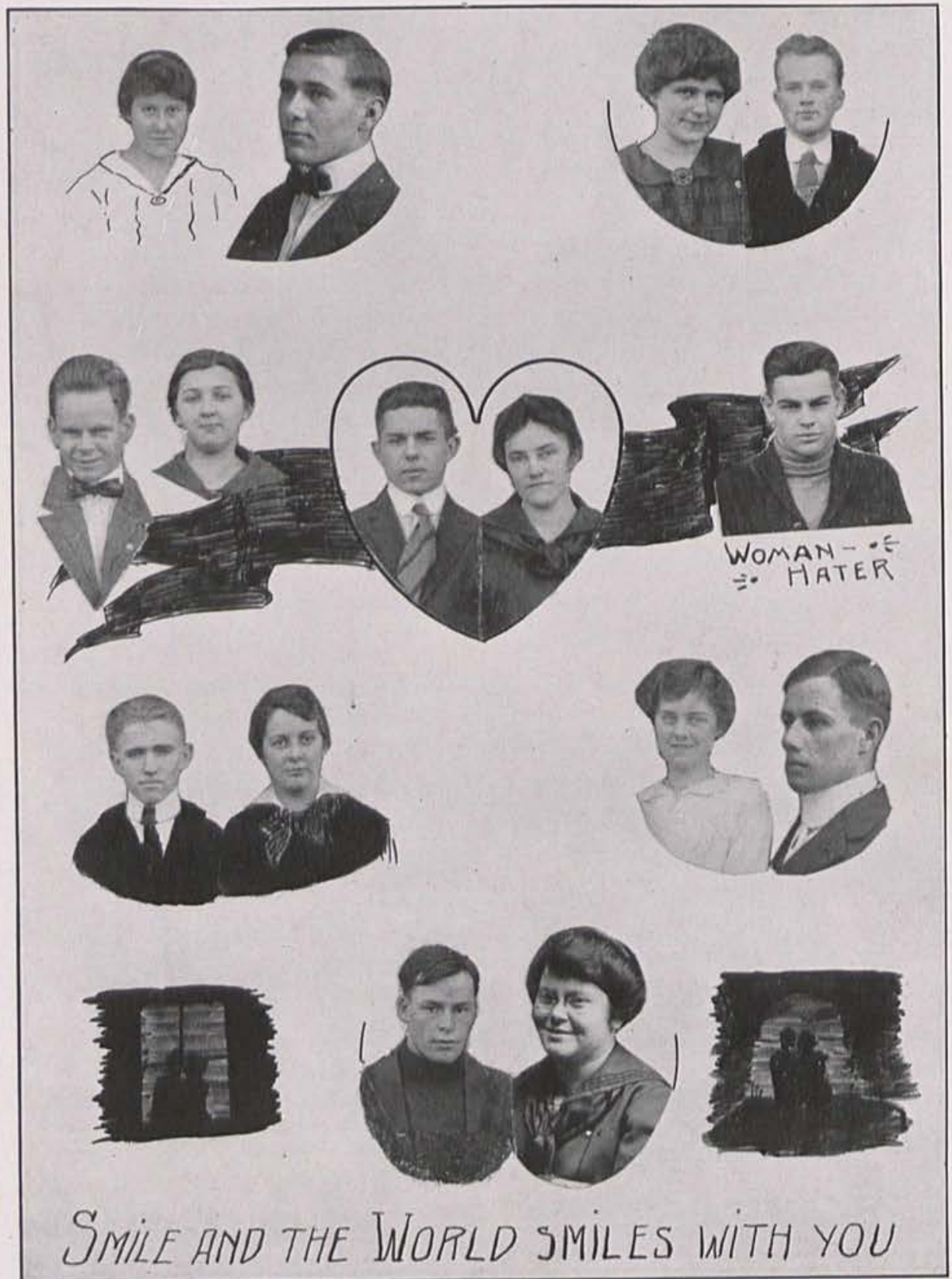




\section{9}
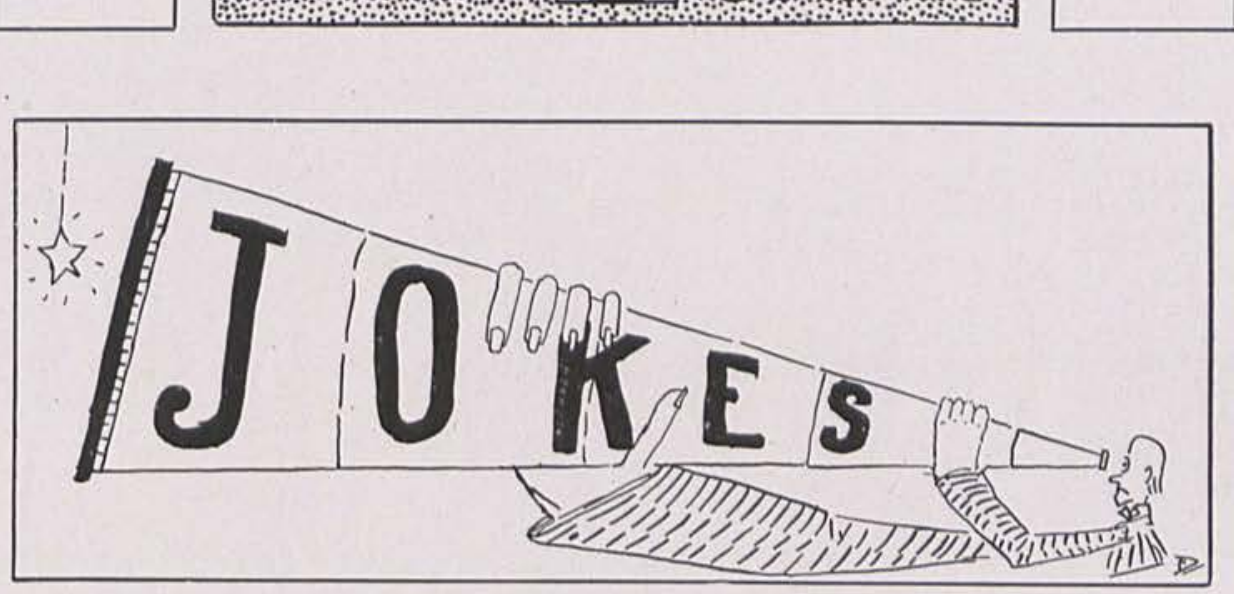

How to kill the Cedrus.

1. Don't buy one. Borrow your friend's book.

$$
\text { Be a sponge. }
$$

2. Look up the advertisers and trade with some other fellow.

$$
\text { Be a quitter. }
$$

3. Never hand in news, jokes, etc. Criticise everything in the book.

Be a knocker.

4. If you are a member of the staff, play tennis, ragtime, or any old thing, except tend to business.

\section{Be a shirk.}

If you think these jokes are old And should be put upon the shelf

Just come around, a few of you,

And hand some in yourself.

The question has often been raised as to whether the $\log$ is in "rythm" with the alge when it "brays."

(Verse Dedicated to Prof. Jurkat.)

Our friend is tall; but where he'd reach

It sometimes makes me wonder,

If now what constitutes his feet

Had never been turned under.

Louisa Finney-Looking at the pictures in the Cedrus:

"Senior pictures?"

Olive Finney - "No, seen yours?"

Mule in the barnyard, lazy and slick;

Boy with a pin on the end of a stick,

Creeps up behind him quiet as a mouse-

Crape on the door of the little boy's house.

Ollie- "Do you know that I got a perfect Physics exam?"

Ann C-Honestly?

Cornwell-Now, look here, don't ask uncomfortable questions. 


\section{9}

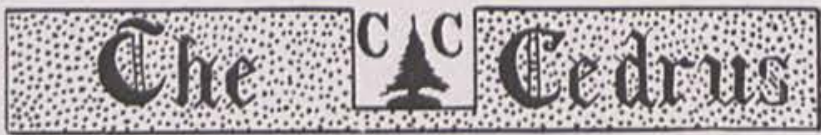

\section{Evolution of the Student.}

Freshman-Please, ma'am, I didn't understand the question.

Sophomore-I don't understand the question.

Junior-What did you say?

Senior-Huh?

Why was the trouble in Chapel on Hallowe'en night like a mushroom?

Because it sprang up in a night.

Why is Ollie Cornwell's nose like iron?

Because it is a specimen of hardware.

Little drops of acid,

Little specks of zinc;

Put into a test tube

Make an awful-odor.

Prof.- How would you discover a fool?

Student-By the questions he would ask.

Speaking of jokes, how many did you put into this publication?

They have been going together for a long time.

Who?

Your feet.

Bill A.-Will you go autoing with me?

Miss Schneder-I should say not! Exhibit my 1917 gown in your 1492 car?

(Original with Rob. C.)

Break, break, break,

On thy cold, gray stones, $\mathrm{O}$ sea!

Broke, broke, broke,

That's what's the matter with me!

Ralph Elder (as a missionary) - "Why do you look at me so intently?"

Cannibal-Because I am the food-inspector.

Prof. Jurkat (In German) - "In Germany the boys and girls go to separate schools, except in the country."

Tom Kennon-" The country for me."

Bill - "Helen, I have a very important question to ask you!"

Helen - "Oh, Bill, this is so sudden!"

Bill- "Please be serious now, Helen, and tell me just what you think."

Helen-"Yes, yes, Bill, go on!" day?"

Bill - "Well do you really think sweet peas should be planted on St. Patrick's

Prof. Allen (In Bible Class) - "How many have seen a unicorn?"

Wallace Anderson-"I have."

Did you ever notice that when cupid hits the mark he always Mrs, it.

Prof. Wright (In History of Education) - "I will expect you to burn midnight oil over this lesson."

Elwood-."I have gas in my room."

Prof. McChesney (in Paidology) - "It doesn't require much ability to keep house in the city. All you have to do is to get a can-opener." 


\section{9

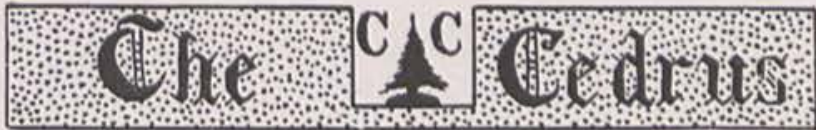

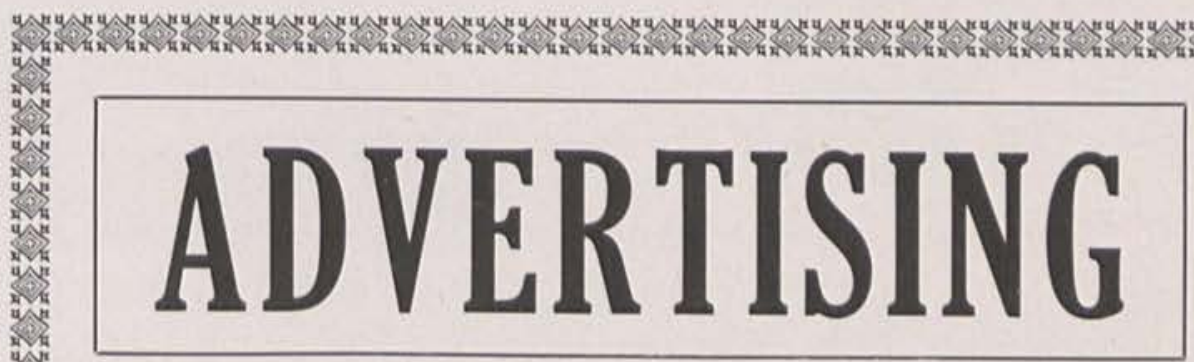

不

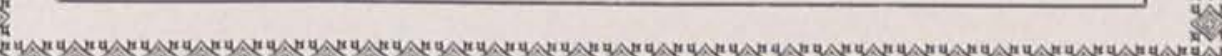

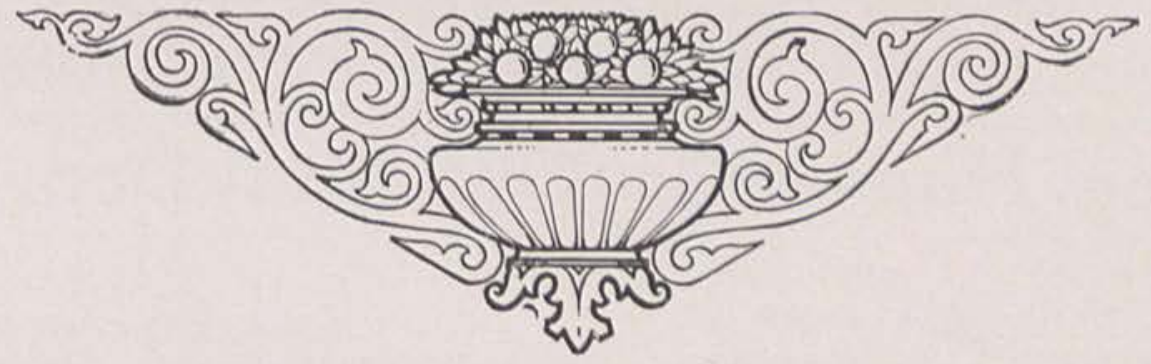




\section{9}

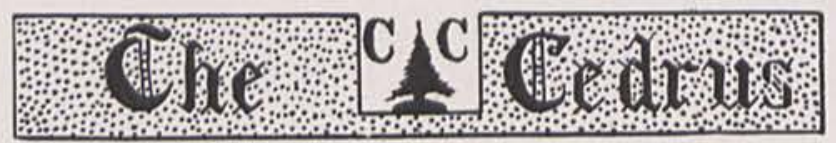

17

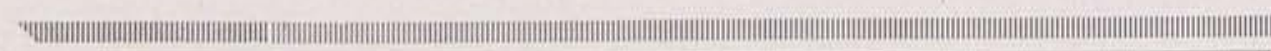

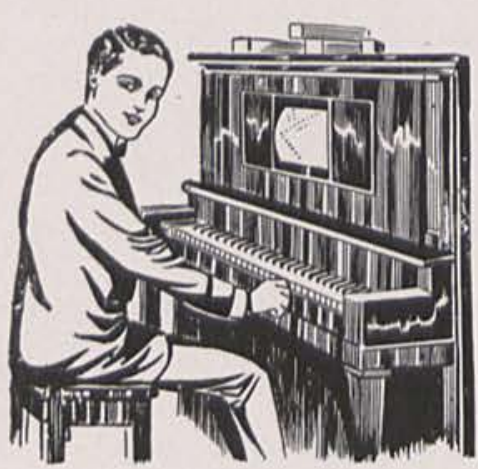

\section{Our Player Pianos}

make musicians of us all. Before the advent of the player piano, the old "still" piano served only as an ornament to all but musicians.

\section{But Not So Now}

Any one may be a musician and play to his heart's content. Each new roll of music means a new joy. Come and see our Player Pianos.

\section{SAWHILL-DOLBEER CO.}

High \& Center SPRINGFIELD, OHIO Reo-Hupmobile-Overland - Dodge

We have been in the

business 13

years.
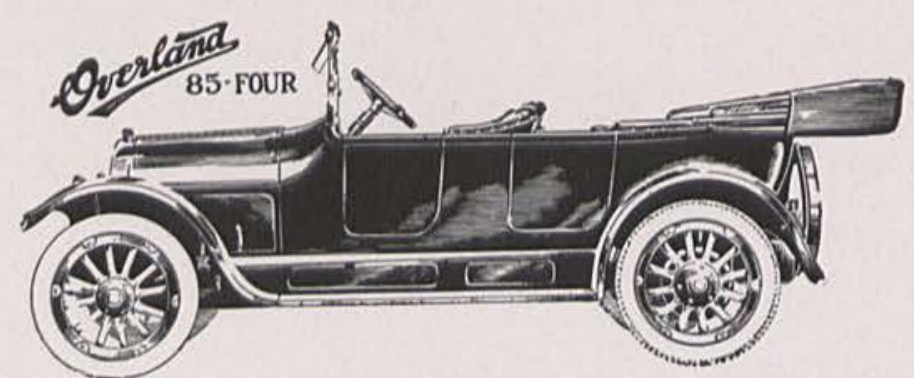

We have sold about 500 cars in Greene, Clinton, and Fayette counties.

THESE are not assembled cars made in fifty different factories, 1 but cars manufactured in their own factories by responsible people and sold by companies who have been in the automobile business years and who take care of their customers after the cars are sold. Ask the people who have purchased cars from us.

\section{Wickersham Hardware Co. Jamestown, Ohio



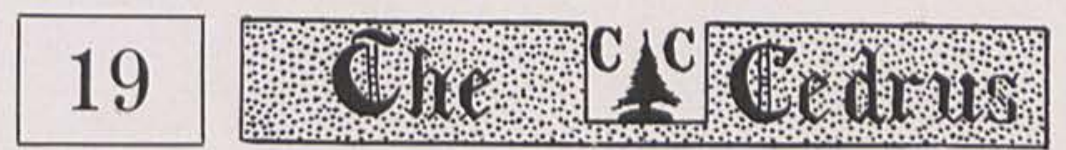

17

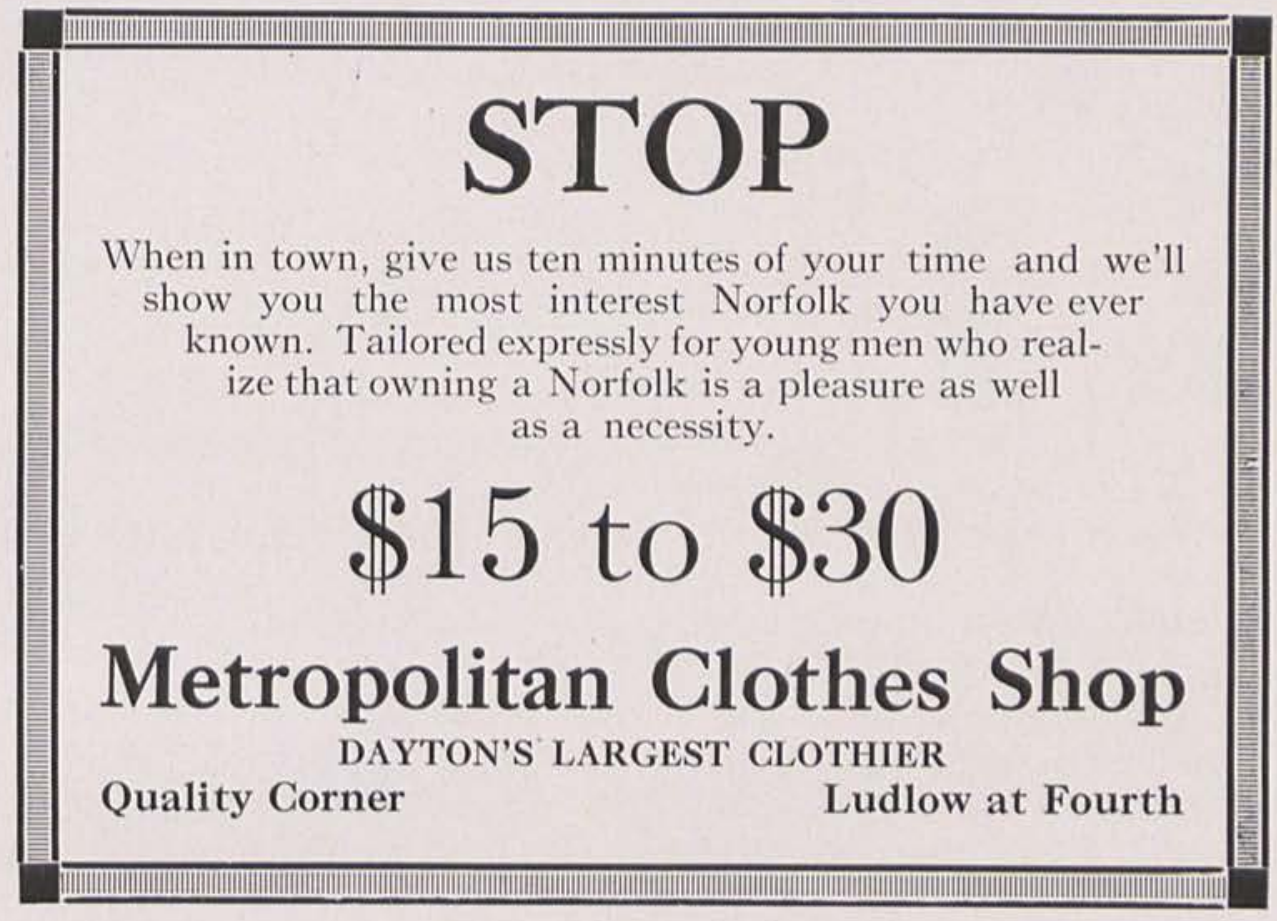

\section{Watt's Quality Ice Creams}

We are in a Position to make Fancy Creams for any occasion

When thinking of ..... SPEGIAL GOODS

Cedarville Agency, Richards' Drug Store

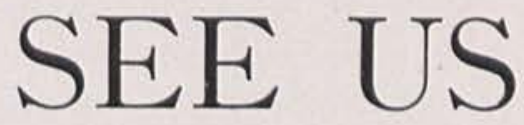



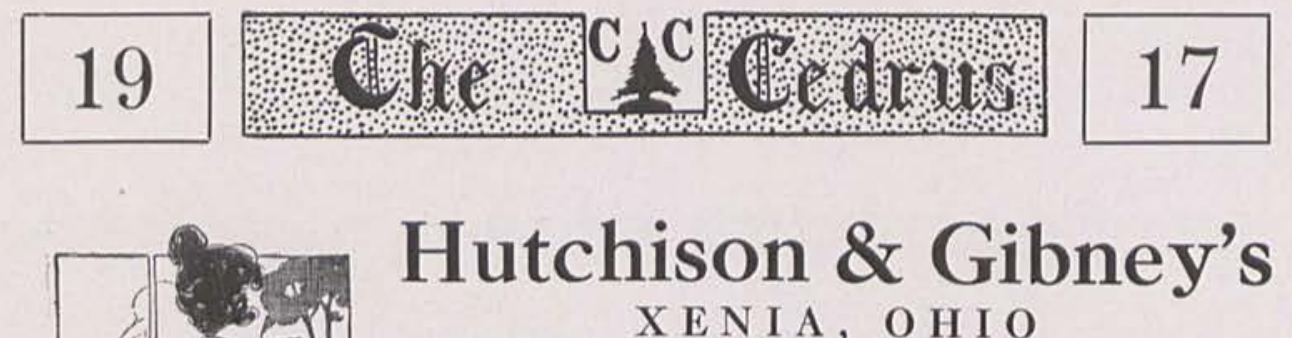

UP-TO-DATE STYLES

Silk and Wool Suits Skirts, Waists, Corsets, Gloves, Hosiery

Rugs, Linoleum, Shades, Curtains Kitchen Cabinets, Coal, Wood and Gas Ranges, Ice Chests, China, 5 and 10 cent Articles, Housekeepers' Needs

\begin{tabular}{l}
\hline FINEST STORE FROM \\
BOSTON TO SAN FRANCISCO
\end{tabular}

Prof. McChesney (In Social Welfare) - " Tell me what you know about Ethryl Alcohol?"

Duncan- "I don't know her."

One student to another- "Duncan wouldn't make a good pall-bearer."

Other Student - "Why?"

First Student- "He's so slow he wouldn't get the corpse there in time for Judgment day." wood.

If the burglar got into the cellar would the coal chute (shoot)? No! but El-

Photographer Wheeler to Prof. Jurkat (while taking group picture of Seminary Faculty and Students) - "Pull your feet back in. I can't get them all in."

\section{The Greene County Lumber Co. XENIA, O H I O}

Has the largest stock of LUMBER in this section of the county - all grades and lowest prices "A SAFE PLACE TO TRADE"

LUMBER DELIVERED TO THE BUILDING SITE 


\title{
Massachusetts Mutual Life Insurance Co.
} Incorporated 1851

\author{
SPRINGFIELD, MASS.
}

Life Insurance is INDIVIDUAL PREPAREDNESS

Are YOU prepared? Talk it over with

C. G. WHITNEY, District Agent

519 and 520 Fairbanks Building

SPRINGFIELD, OHIO

Doc. Richards, Jim Chesnut, and McClure speaking of Coulterville, Illinois.

Doc.- "I was through that town once selling nursing bottles."

MeClure - "Yes and I went through that town about 1906 using one of those articles, you were speaking of, Doc."

There was a good joke for this space, but it failed to pass the Board of Censors.

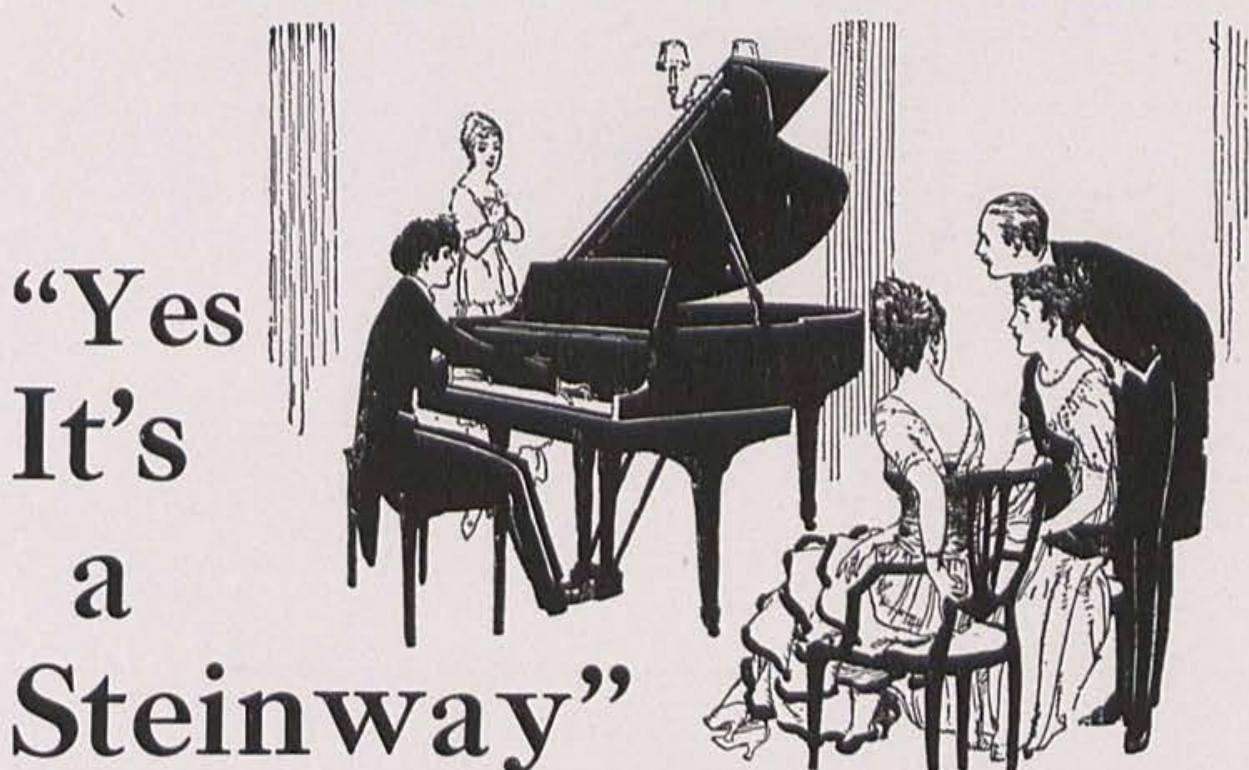

TSN'T there supreme satisfaction in being able to say that of the piano in your home? Would 1 you have the same feeling about any other pianos? "It's a Steinway." "Nothing more need be said. Everbody knows you have chosen wisely; you have given to your home the very best that money can buy. You will never even think of changing the piano for any other. As the years go by, the words "It's a Steinway" will mean more and more to you, and thousands of times, as you continue to enjoy through life the companionship of that noble instrument, absolutely without a peer, you will say to yourself: "How glad I am I paid the few extra dollars and got a Steinway.'

\section{STEINWAY \& SONS}

205 North Main Street

DAYTON, OHIO 


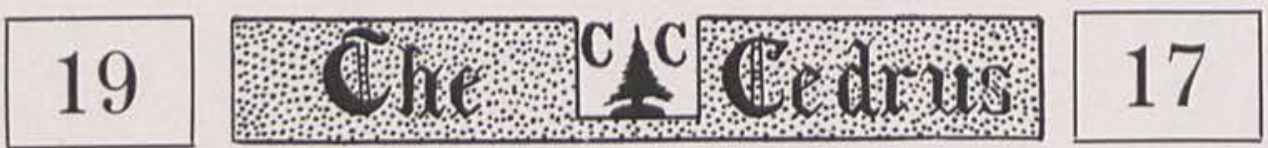

\section{"Quality First"}

There are lots of places to buy Good Furniture but ONLY ONE PLACE to BUY THE BEST

J. A. BEATTY \& SON

Dependable Furniture, XENIA, OHIO

Agents for the "MANDEL" Phonograph

Play any make records.

\section{Auto Service Co.}

FRANK E. LYONS

Expert Vulcanizing

Ajax Tires 5,000 Miles

Silvertown Cord Tires

We repair all Makes of Tires. Free Air at All Times.

West Main St. XENIA, OHIO

B O TH PHONES

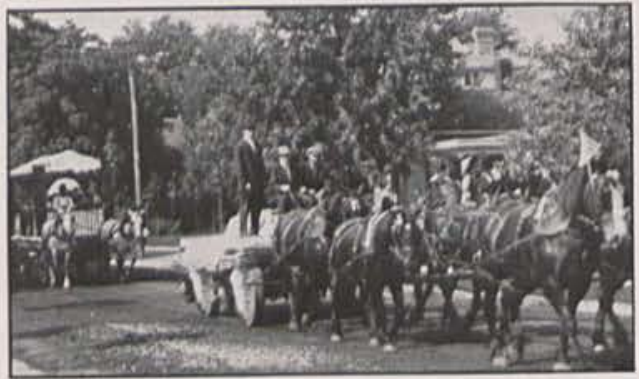

Thorb Charters JEWELER

Now Located at

44 E. Main Street XENIA, OHIO 


\section{9}
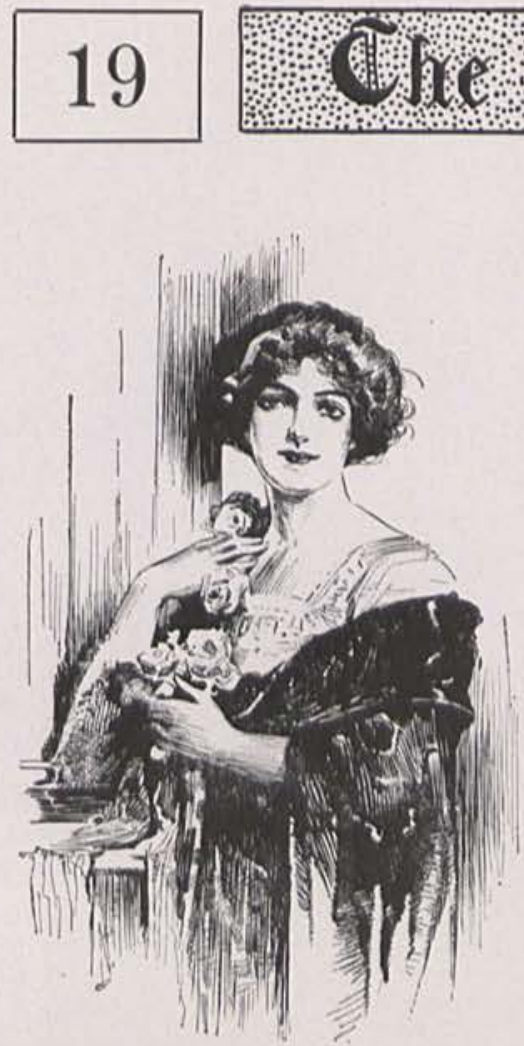

Most things can be any1 body's gift - your portrait is distinctively, exclusively yours.

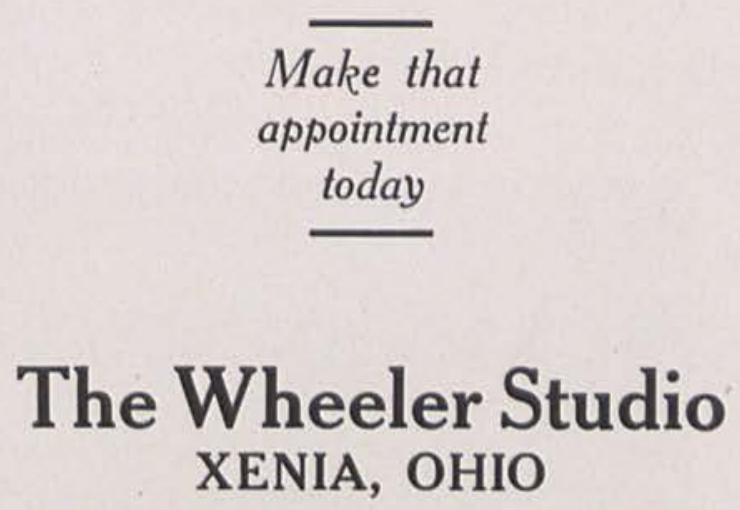

The HOME Bakery

Bakes fresh Bread every day.

Delicious Pies, Cakes, and

Pastries a Specialty.

Delivery Every Day.

\section{JACOB SIEGLER}

Phone 65 CEDARVILLE, OHIO

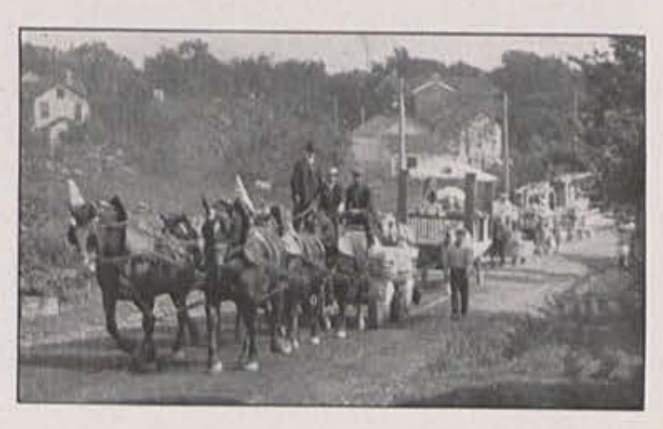

The Cedarville Herald

ESTABLISHED 1878

Commercial Printing of All Kinds

CEDARVILLE, OHIO 


\section{9}

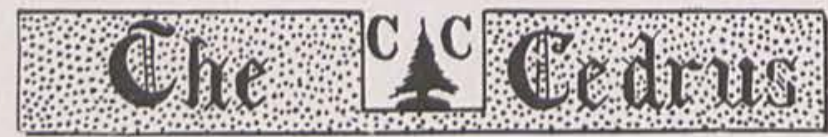

\section{Hart, Schaffner and Marx}

Varsity Fifty-five for Young Men, $\$ 18$ to $\$ 35$

CLOTHCRAFT Clothes, All Wool, $\$ 12$ to $\$ 16.50$

$$
\text { C. A. WEAVER }
$$

\section{Opposite Court House}
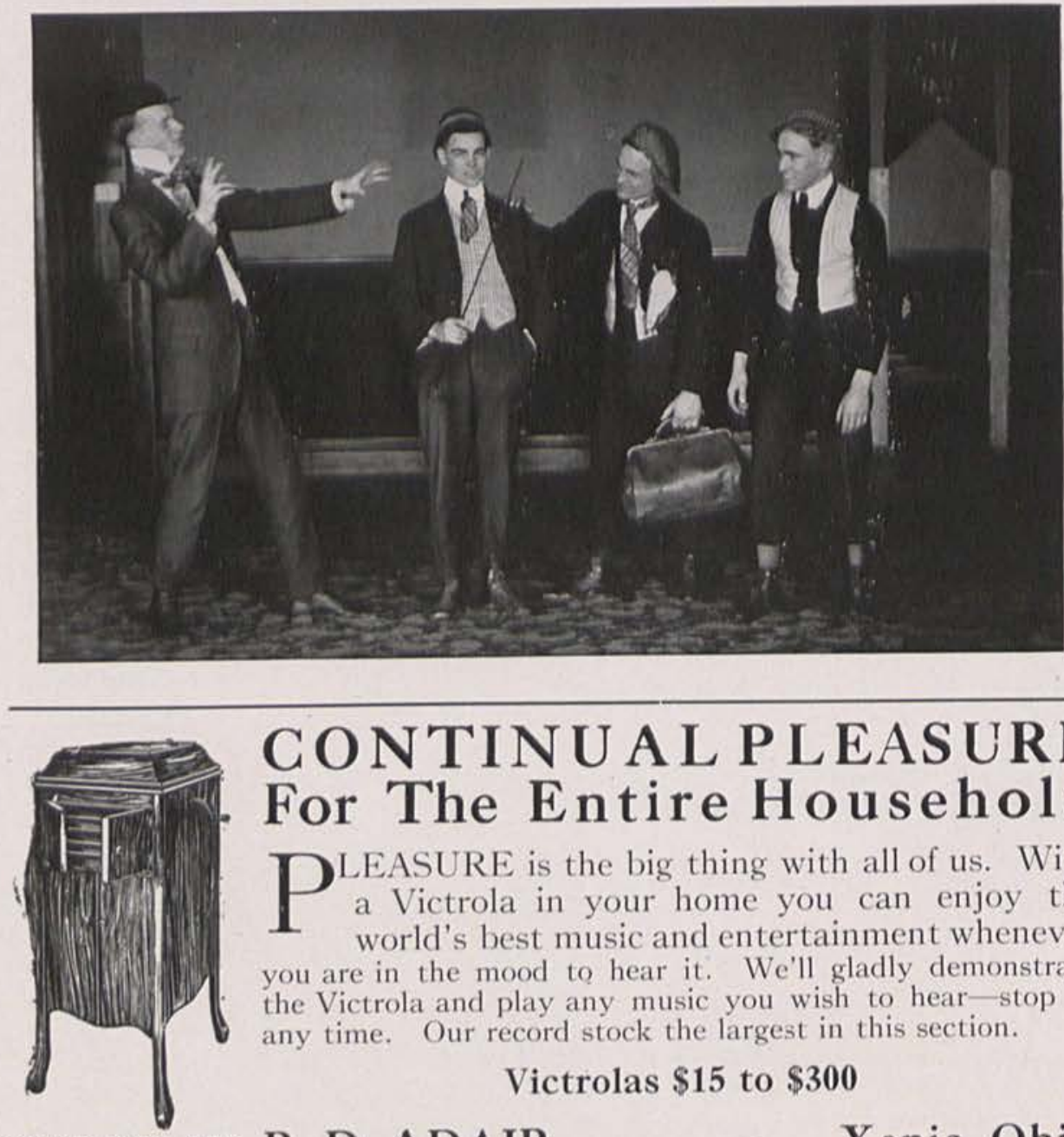

CONTINUAL PLEASURE For The Entire Household

DLEASURE is the big thing with all of us. With

a Victrola in your home you can enjoy the world's best music and entertainment whenever you are in the mood to hear it. We'll gladly demonstrate the Victrola and play any music you wish to hear-stop in any time. Our record stock the largest in this section.

\section{Victrolas $\$ 15$ to $\$ 300$}

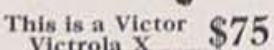

R. D. ADAIR

Xenia, Ohio 

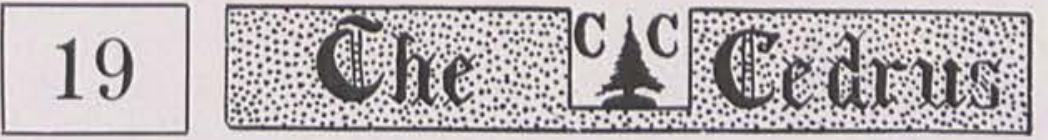

Prof, Jurkat - "What language does a man learn just before his death?" Student-"I don't know."

Prof. Jurkat-"The finish."

Miss Burns (in Physical Geography Class) - "Name the main classes of soils." Miss Finney - "Transported, Sedimentary, and Colloquial."

Not Legal Offenses.

Breaking into-society.

Picking - your own way.

Stealing - hearts.

Coining-money.

\section{Wallace Irvine}

\author{
W A T C H \\ REP A I R I N G \\ My Specialty.....
}

Also SPEcIal WORK AND Orders TAKEN FOR All Kinds of JeWElry

\section{Osterley's}

HATS for all OCCASIONS

and at PRICES

to suit every

PURSE

\section{BABB means BEST}

\section{3rd Year}

Hardware, Buggies, Implements, Harness, Engines, Paints

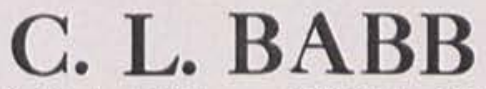

$16 \mathrm{~S}$. Detroit St. XENIA, OHIO

\section{"TRUTH"}

"Oh my, oh my," said Chadawick.

"These awful girls they make me sick. I wish that I was miles away,

Where women wouldn't dare to stay." But Chadawick's not so absurd, For very recently I have heard, That every night on the avenue, He's visiting until after two.
Try....

POST'S Bread, Cakes, Pies, and Doughnuts

\section{"like mother used to make"}

\section{SEE....}

Walter Boase for

Groceries, Fruits, and $V$ egetables

We Buy Your Cream.

Phone 31

CEDARVILLE, OHIO 


\section{9}
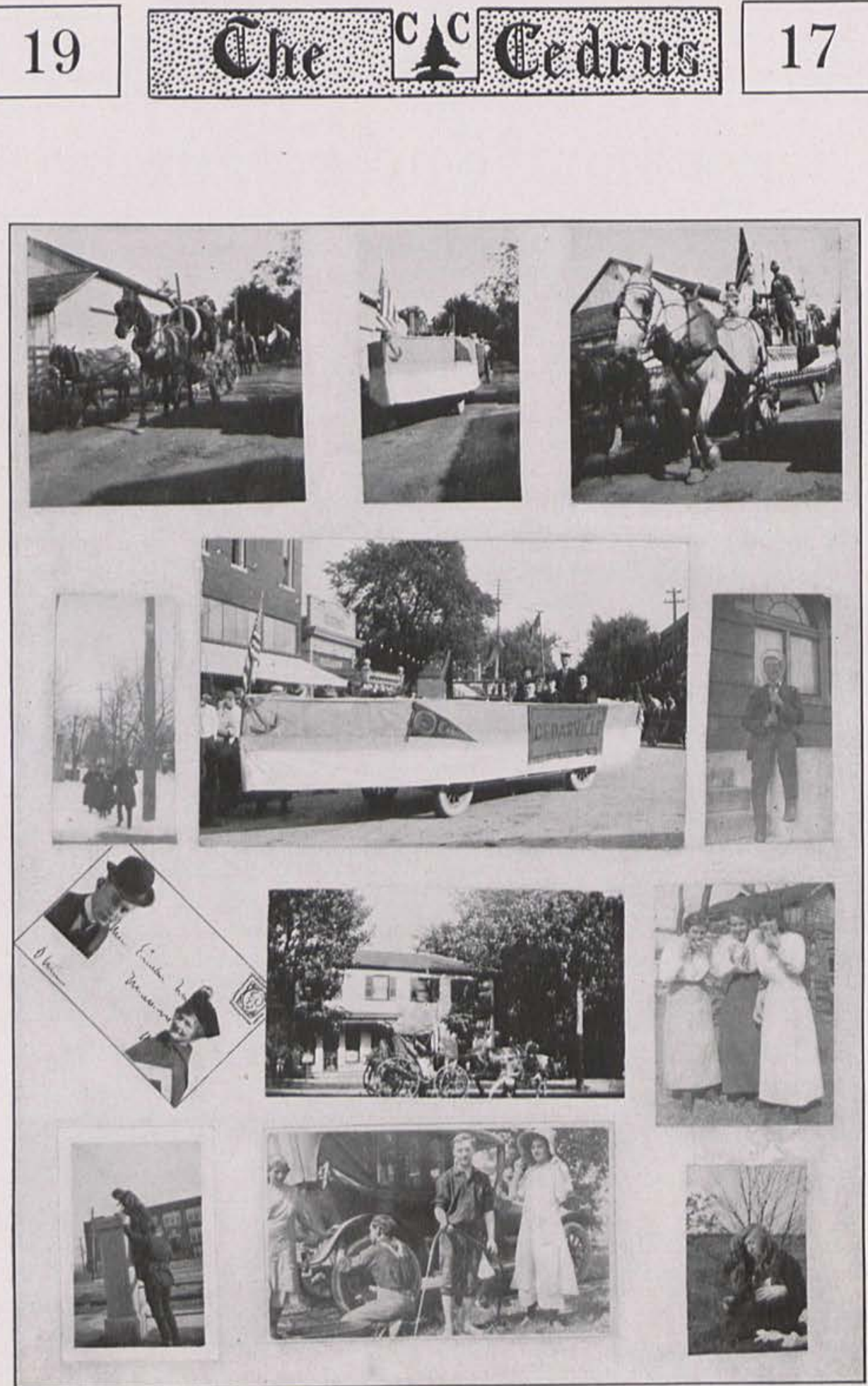


\title{
19

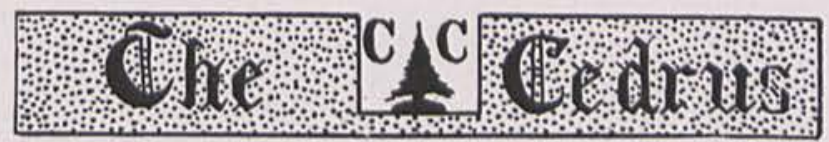

\section{The Tarbox Lumber Company}

\author{
Have a complete line of BUILDING MATERIALS
}

Estimates cheerfully made. Best grades at

reasonable prices.

\section{Phone 33}

\section{Cedarville, Ohio}

Miss Taylor, in Physical Geography - "What is the use of all the sand in the sea?"

Roger Collins - "That's what they scour the sea with."

"Dear Jake: Come tomorrow evening sure. Papa is at home, but laid up with a sore foot." Sally.

"Dear Sally: I can't come tomorrow night. I am laid up on account of your papa's sore foot." Jake.

What goes up must come down,

So says the ancient adage;

But one exception has been found-

The price of potatoes and cabbage.

Why may Paul Ducan marry many a wife and yet be single?

Because he is going to be a clergyman.

Horton passing back of the library, while faculty was holding its monthly meeting, observed someone's feet on the table and was heard to remark, "What strange things come up in faculty meeting."

Prof. Allen-What time was this psalm written?

Ellen Tarbox - " It is thot, about the time of Absalom's resurrection."

Prof. McChesney - "Beauty is only skin deep."

Chad. - "Some people ought to be skinned."

Ralph Elder - "Women are inclined to be stubborn once in awhile."

Pauline Smith-"That works the other way also."

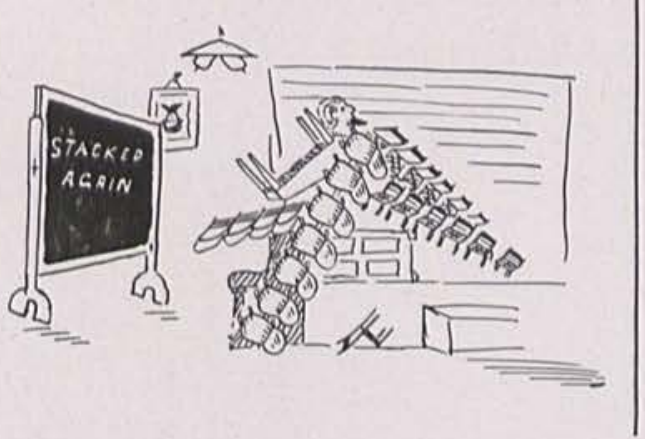

Doherty - "What are you doing, fishing?"

Elwood-"No, you simp. I am teaching these little worms to swim. See, there is one swimming on his own hook now."

Boy, gun, Joy, fun;

Gun bust, Boy dust. 


\section{9}
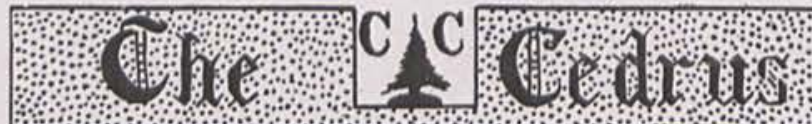

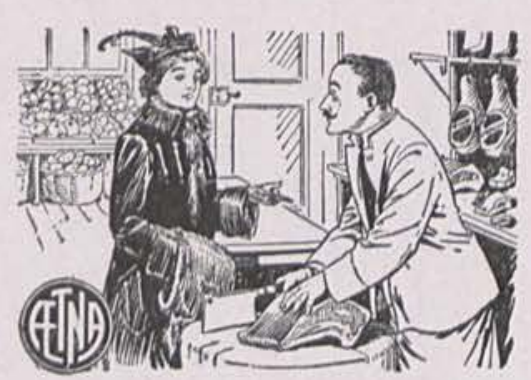

"Yes, Give Me the Very Best, Please"

I don't wonder you're surprised, Mr. Todd, that I should buy luxuries we ordinarily aren't accustomed to, in our modest way of living; especial. ly when my husband has been sick so long.

So very good of you to offer to extend credit, but indeed I'd rather pay cash the same as I always have done.

I can't resist telling you about our AETNA COMPREHENSIVE HEALTH PGLICY.

You see, we've been getting $\$ 50$ a week from the policy while my hushand was in the hospital-and we get $\$ 25$ a week now and will receive payments, if we need them, up to a whole year.

You might think it over and see if you don't believe it would be a mighty good thing for you to

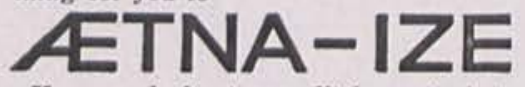

You can do it at very little cost-just telephone-or write-or call on

Savage \& McMillan E. Main St. XENIA, OHIO

Get your GROCERIES, FRUIT, and VEGETABLES at

\section{J. M. Willoughby Corner Grocery}

Cash Paid for Butter Fat

All Orders Delivered Quickly

Phone 85 Cedarville, OHio
Mantels, Tiles, and Grates $51 \mathrm{~W}$. High St.

\section{McDaniel}

Fireplace Accessories

Fixtures and Electric Wiring

SPRINGFIELD, OHIO

\section{Clothes Talk!}

The Better They Look

The Louder They Talk

We Clean, Press, and Repair

them and give them a tone of

DISTINCTION

Call us

We'll Call

Xenia Dry Cleaning Co.

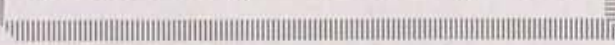

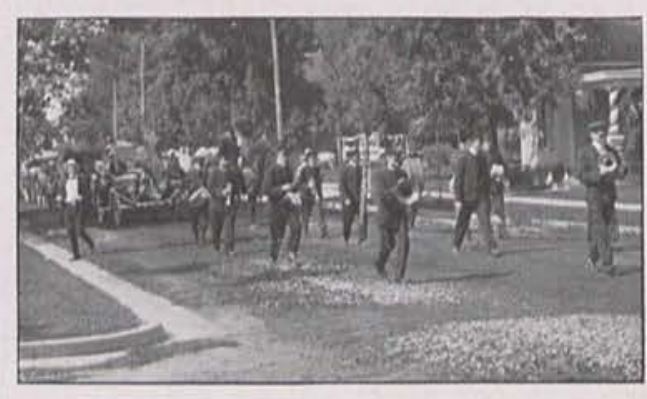

\section{Galloway \& Cherry}

11 E. Main St. Xenia, Ohio 


\section{9}

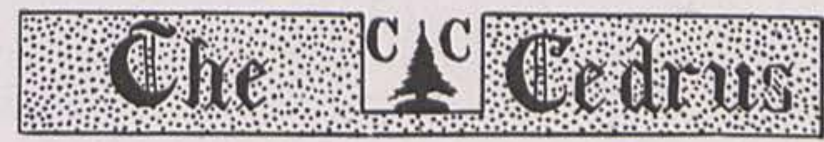

17

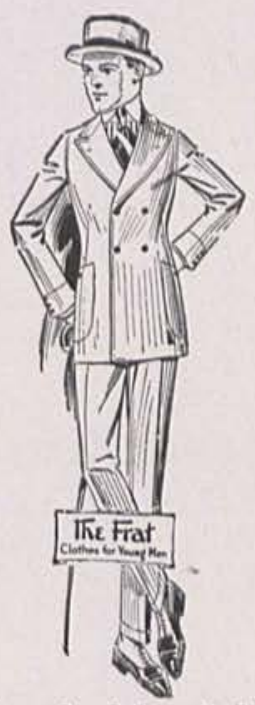

Snappy Togs for Men \& Y oung Men

\section{The Criterion}

A Store for Dad and the Boys

Fenia, Obio
Jobe $\underset{\text { XENAL, OHIO }}{\text { Brother }}$ Co.

Exclusive Distinctive Models in Women's Apparel

- Remarkable collection from the standpoint of fashion, material, and value.

- We display the newest in Millinery, Boots,Gloves, and Dress Accessories.

Richards' Drug Store

\section{STUDENTS' \\ Headquarters}

Phone $203 \quad$ Cedarville, Ohio

\section{LEO ANDERSON, D. V. M. \\ VETERINARIAN}

PHONES: $\{$ RESIDENCE 2-81

CEDARVILLE, OHIO

TRY US ON SHOES

YOU WILL SAVE MONEY

\section{S. and S. SHOE STORE}

E. MAIN STREET

XENIA, OHIO

Janet (in extempore) - "We should choose a variety of vegetables such as fish, meat, and eggs.

Prof. McChesney - "The topic for Y. M. C. A. tomorrow is, "The regalvanizing of indifferent members." "I also wish to announce that the Y. W. C. A. will have an insulation of officers."
(@) THE THLE OF A TRUNK

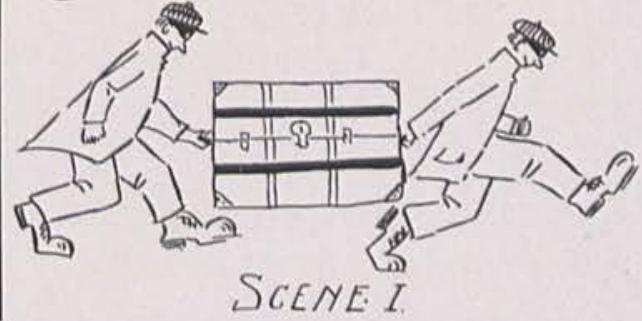

SCENE I 


\section{9}

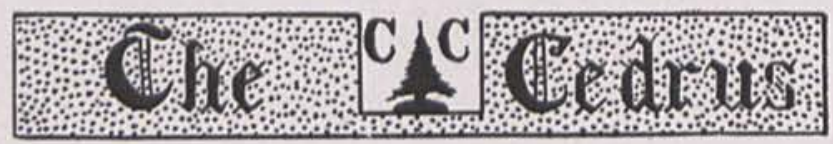

\section{Our Profit-Sharing Plan}

Will materially assist you in solving your problem of HIGH COST OF LIVING, in Men's and Boys' Clothing, Hats, Furnishing Goods and Shoes.

It means a SAVING of $4 \%$ - It will pay $\mathbf{U}$ to investigate.

\section{HOME CLOTHING CO.}

SPRING FOOTWEAR in all the newest offerings at reasonable prices.

We will sell the best of everything in shoes.

\section{FRAZER'S SHOE STORE}

When you want UP-TO-DATE PHOTOS call on

\section{CANBY}

Xenia's Leading

PHOTOGRAPHER

34 E. Main St. Xenia, Ohio

Prof. Jurkat (In History Class) "What was the difference in the death of Joan of Are and Louis XVI?"

Mr. Cornwell-I do not know.

Prof. Jurkat- - That's easy, one was a cold chop and the other a hot stake."

"That song always moves me," said Ollie, as Ann rose from the piano at 11 P. M.

"How glad I am I sang it," replied Ann, with a well-bred glance at the clock.

Mrs. Russell- "What makes your voice so husky, Mr. Anderson?"

Bill- "I just came from the cornfield."

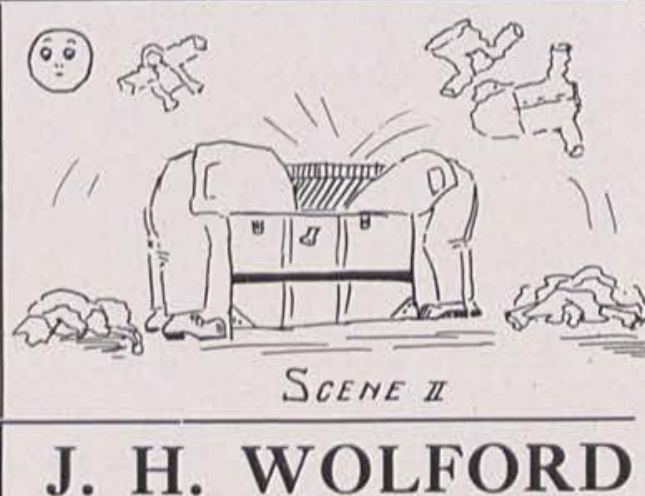

Succeeded by Ralph Wolford

General Blacksmithing

and WAGON MAKING

Plow Work and Buggy Work

Oxy-Acetylene Welding

Automobile Painting

and TRIMMING

RubBer Tires APPlied 


\section{9}

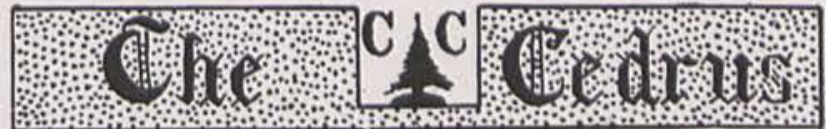

\section{ROBERT BIRD AND SONS CO.}

The Store That The Students Make Their Headquarters WE TRY TO PLEASE THEM

For the GIRLS

A full line of Furnishing Goods, Kid Gloves, Corsets, Silk Hosiery, etc.

\section{For All STUDENTS}

Tennis and Basket Ball Shoes, Sweaters, Pennants, etc.
For the BOYS

Wilson Bro. Famous $\$ 1.50$ Shirts; Rice and Hutchins $\$ 5.00$ and \$6.00 Shoes: Royal Tailored Suits; Snappy, Stylish Hats and Caps: Nifty Neckties, Arrow Collars, P. Q. A. and Mentor Underwear, Silk Socks, Belts and other merchandise of merit.

We take this opportunity to thank all the students for their patronage.

COME AGAIN

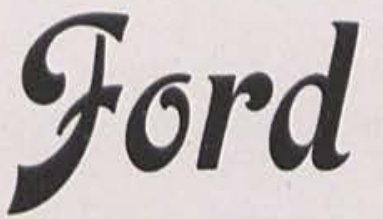

Authorized Sales and Service R. A. MURDOCK

Main Street

CEDARVILLE, OHIO

Bill A. (In chapel after we broke down on No. 123) - "Well, we got as far as Sing Sing any how."

Student - "Are you going to take somebody to the lecture tonight?"

Mr. Duncan-" Yes, I have a seat."

Anna Collins (In Literature Class) - "After meeting a number of hardships he was finally married."

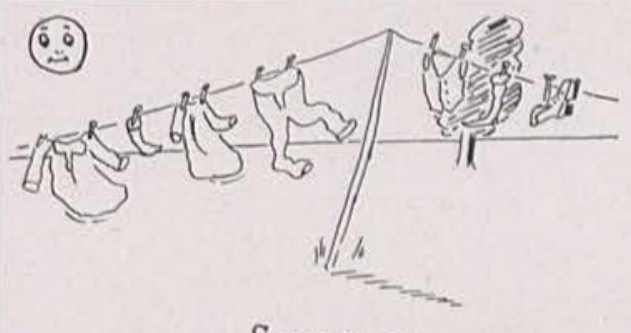

Bell Phone 681

Citizen Phone 174

\section{FLOY ANDERSON, Florist}

FLOWERS FOR ALL OCCASIONS

THE STORE THAT TREATS YOU RIGHT KATZ \& MADDUX

Clothes for Men, particularly Young Men

Opposite Citizens National Bank

XENIA, OHIO 


\section{9}

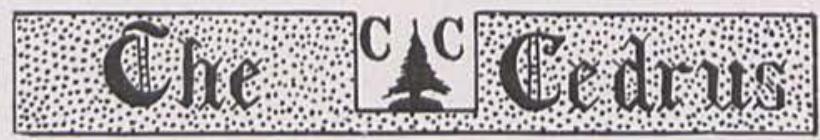

Prestige in Piano Buying When You Buy from the

\section{SUTTON MUSIC STORE}

15th Year on Green Street, XENIA, OHIO

Over 1000 Satisfied Customers. Piano Refinishing. Tuning and Repairing a Specialty.

\section{BOTH PHONES}

We pay the highest possible net cash price for Cream.

\section{The Western Ohio Creamery Co. XENIA, OHIO}

J. M. WiLloughbY, Cedarville Representative

(2)

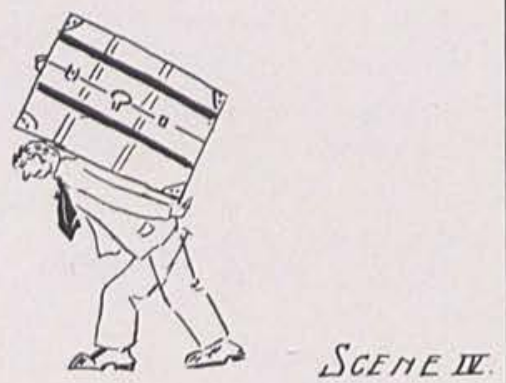

Walk-Over Shoes For JुCen and Women $\$ 3.50$ to $\$ 10.00$

Moser's Shoe Store XENIA, OHIO
WILLARD Storage Batteries

\section{Oscar L. Pidgeon}

S. Detroit St. XENIA, OHIO

Jim - "Are you cold?"

Irene - "Yes, dear."

Jim- "Want my coat?"

Irene (Leaning over)-Just the sleeves.

Recently Miss Schneder received a letter, and was afterward heard singing, "None like thee -None like thee."

Both Phones 71

The Greene County Hardware Co.

The House that Makes Good Xenia, Ohio 


\section{9}

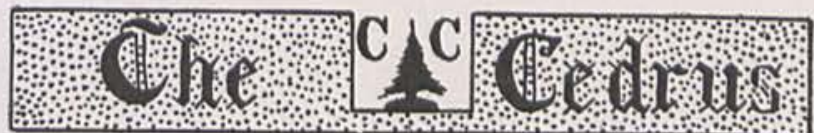

\section{Paint and Flower Seeds}

\section{Little beds of flowers,}

Little cans of paint,

Make attractive neighborhoods out of these that ain't.

Buy them from

\section{Kerr and Hastings Bros.}

\section{Parody by Lonisa Greer.}

Good-bye, Students,

Good-bye, Students,

Good-bye Students,

We're going to take a ride,

Meryl and I we roll along, roll along, roll along,

Meryl and me we roll along

O'er the broad highway.

(Rest of poem deleted by Censor)

The morning after the night before.

Bob. C. (In Bible Class reading) - "A thousand years in thy sight are but as yesterday when it is past, and as a watch in the night."

Prof. Allen - "What is meant by a watch in the night?"

Bob. C. (yawning) - "Well, we all know how short these nights are."

Harriet Stewart (After prayer meeting at Wright's) - "Lets take some kindling

\section{Grow with Us!}

Place your savings with us on which we pay $4 \%$ interest compounded semi-annually.

\section{The Exchange Bank}

\section{CEDARVILLE, OHIO}

Capital and Surplus,

Resources and Liabilities, $\quad$ - $\quad$ - $\quad$ - $\$ 300,000.00$ 


\section{9}

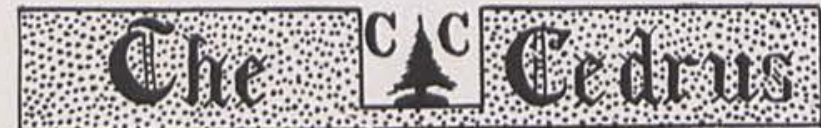

Make our store the place you feel at home. We appreciate your presence and patronage.

\section{McKee Hardware \\ The STANTON STUDIO \\ CEDARVILLE, OHIO}

Sittings and Delivery made in Cedarville, finishing done by Stanton's, Springfield, Ohio: Gallery open Thursday, Friday, and Saturday of each week.

\section{J. VICTOR TARR, Artist, Mgr.}

Pictures enlarged and framed; all sizes of frames made to order. 18 years an Artist.

\section{J. VICTOR TARR, Stanton Studio, Cedarville, Ohio}

home, we want to get something out of this prayer meeting."

Dr. MeChesney (discussing diet of the Jews) - "They will not eat milk and meat together, but will eat milk and honey."

George Smith (in surprise) - "Milk and honey! Gee-Whiz- They must be galvanized."

Irate Prof. (to Latin Class) - "Will the cavalry in the rear of the room please ride forward, tie your ponies to my desk, and retire again in good order."

Doherty fails to answer at roll call in class.

Prof.- "I suppose the gentleman has discovered a cut he hasn't used."

Prof. (in Physiology class) - "Is there any cure for bow legs?"

Duncan- - None that I know of except to cover them up."

Student (writing home) - "How do you spell financially?"

Another Student- "F-i-n-a-n-c-i-a-l-1-y, and there are two E's in Embarrassed." 

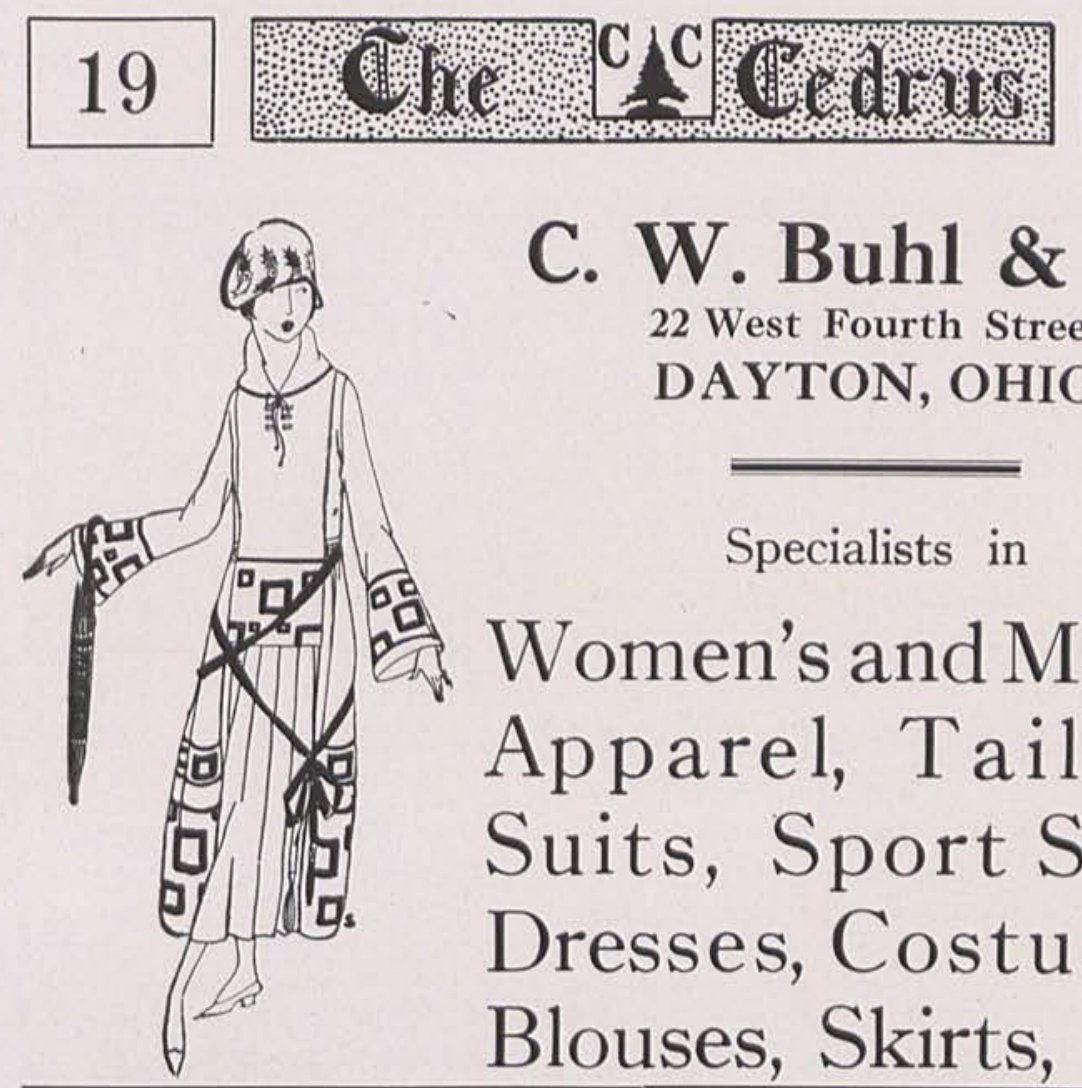

\section{W. Buhl \& Co. \\ 22 West Fourth Street \\ DAYTON, OHIO}

Specialists in

Women's and Misses'

Apparel, Tailored

Suits, Sport Suits,

Dresses, Costumes, Blouses, Skirts, Furs

MEAT MARKET

FRESH and SMOKED MEATS Phone 104 Cedarville, Ohio

J. H. NAGLEY

NAGLEY BROS.

M. C. NAGLEY

FUNERAL DIRECTORS

PHONES: Home 159 and 40 AUTO SERVICE CEDARVILLE, OHIO

\section{“Cedar Inn" $\quad$ Kredel \& Alexander}

- The place for Travelers, Students, or anyone wishing a good home-like meal; alsolunches or short orders. Everyone welcome at all times.

Mrs. Geo. H. Smith Proprietor
Fashionable Clothiers

Hatters, Furnishers

:: FOR MEN ::

Cor. Main and Limestone SPRINGFIELD, OHIO 


\section{9}

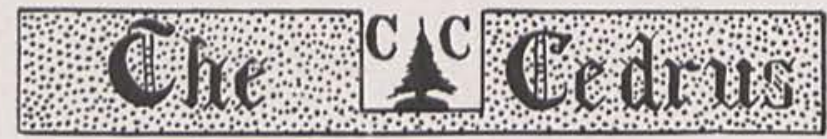

\section{THINK}

While considering the purchase of Memorial Work, of superior equipment, facilities, and ability of

The George Dodds \& Sons Gr. Co. XENIA, OHIO KEENE, N. H. MILFORD, MASS.

(Awarded first prize as the finest Granite and Marble works in the U. S.) Write for free copy of handsome Art Booklet today.

\section{The relestern Theological Seminary}

\section{N. S. PITTSBURGH, PA.}

Founded by the Gen. Assembly, 1825.

A Seminary for College Graduates

A complete modern theological curriculum is offered to students of all denominations. Elective courses leading to degree of B. D. Graduate courses of the University of Pittsburgh open to properly qualified students of the Seminary. Exceptional library facilities. All Seminary buildings are new with modern equipment, Gym., social hall, and students' commons.

Next term opens Sept. 18, $1917 . \quad$ For information apply to Pres. JAS. A. KELSO, Ph. D., D. D.

\section{The MissouriState Life Insurance Co. St. Louis, Missouri}

$7 \mathrm{HE}$ Missouri State Life writes guaranteed contracts, with Loan values at the end of the first year.

Cash paid up, extended Insurance, and Loan

Values the second year and every year thereafter.

The Policy contract has a provision in it for insuring Loans, provided the insured can give a certificate of good health. Then in case of death it cancels the Loan and the Policy is paid in full to the beneficiary. The Company closed 1916 with assets \$14,142,052.49. Guarantee Fund to Policy holders $\$ \mathbf{2 , 7 0 8 , 3 9 7 . 6 5}$. Insurance in force, paid for basis, $\$ 129,199,279.00$.

\section{P. A. ALTLANT, General Agent Washington C. H., Ohio.}




\section{9}

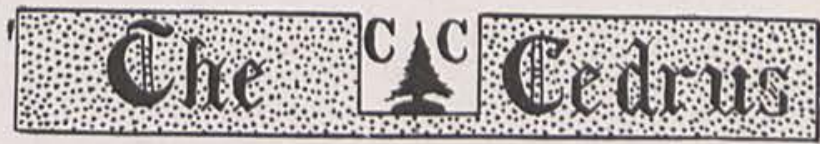

17

\section{"Sheffield" for Steel \\ "Sterling" for Silver "Aldine" for Printing}

are Hall Marks of Quality

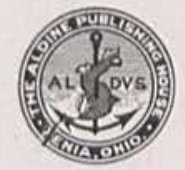

The Aldine Publishing House GEO. I. GRAHAM \& COMPANY

College Publications

Engraving - Printing - Binding

Gazette Bldg.

XENIA, OHIO

Samples and Prices on Request.

Both
Telephones
J0 H. WHERAL DIREGTORS AND EMBALMERS
OFFICE OPEN DAY AND NIGHT
22 EAST MARKET STREET

Miss Schneder, in College English, asking different members of class to recite: Miss Elder you may give, "The day is done" -

- "No, I don't want a girl, I want a fellow."

Why is married life in college like a steamboat?

Because it is likely to blow up.

\section{W. L. Clemans}

Real Estate, Loans -AND -

Insurance Agency ESTABLISHED 1896

CEDARVILLE, $\mathrm{OHIO}$
In Extempo Class, when criticizing Elwood:

Bill C.- "A rattling good speaker, isn't he?'

McClure " Yes, he rattles, and that's about all he can do."

Prof. Allen (after several vain attempts to elicit an answer from a $\mathrm{Bi}$ ble student) - "Now, you can answer this question, even if you haven't studied your lesson. 


\section{9}

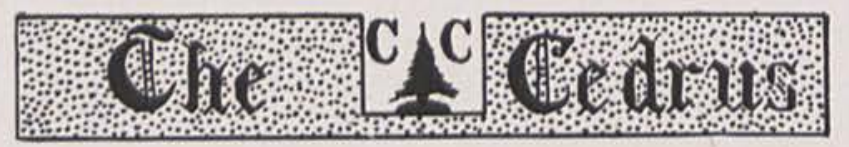

17

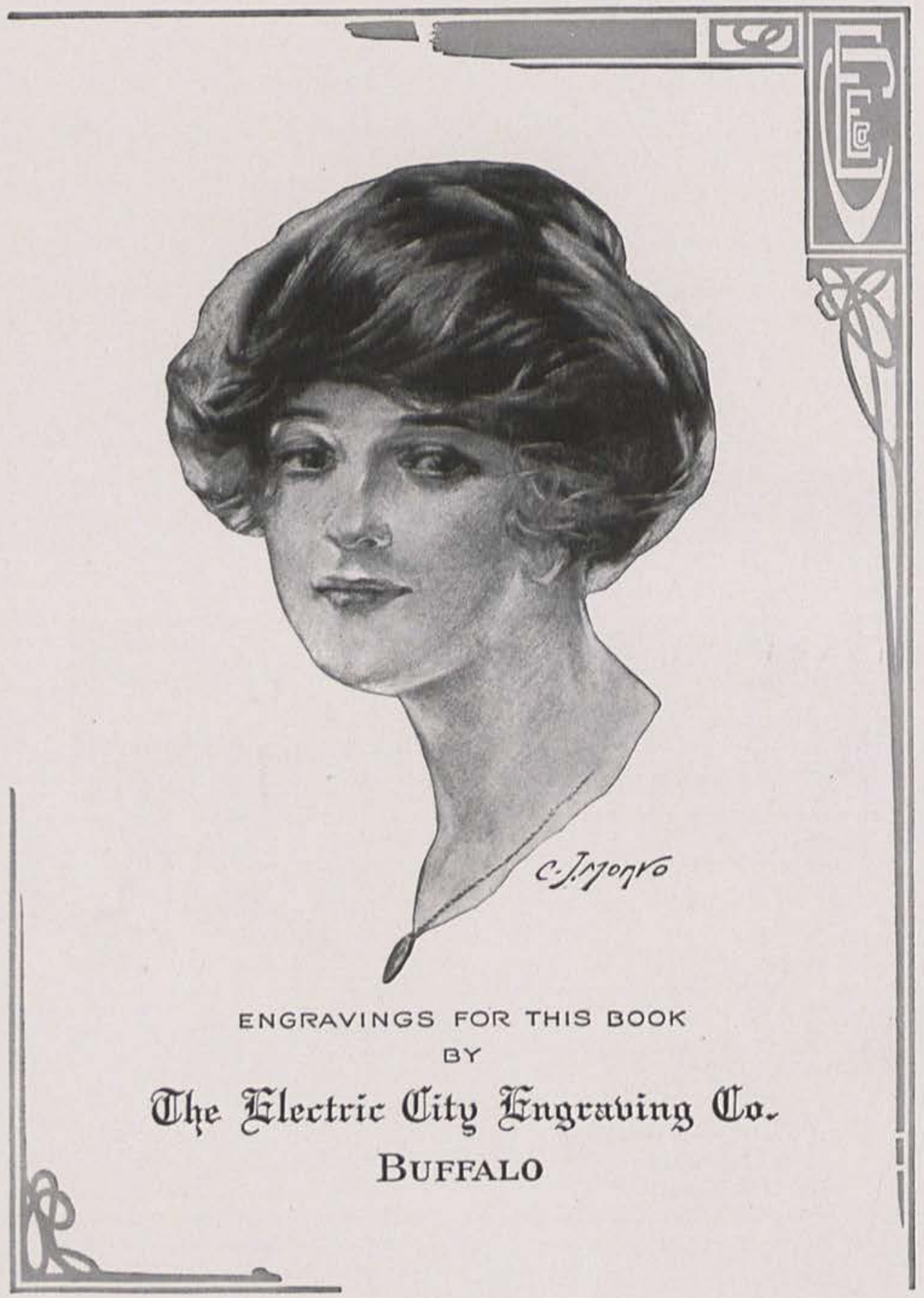




\section{9

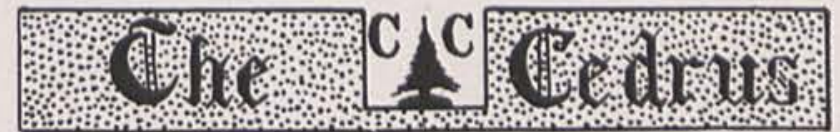 \\ 17}

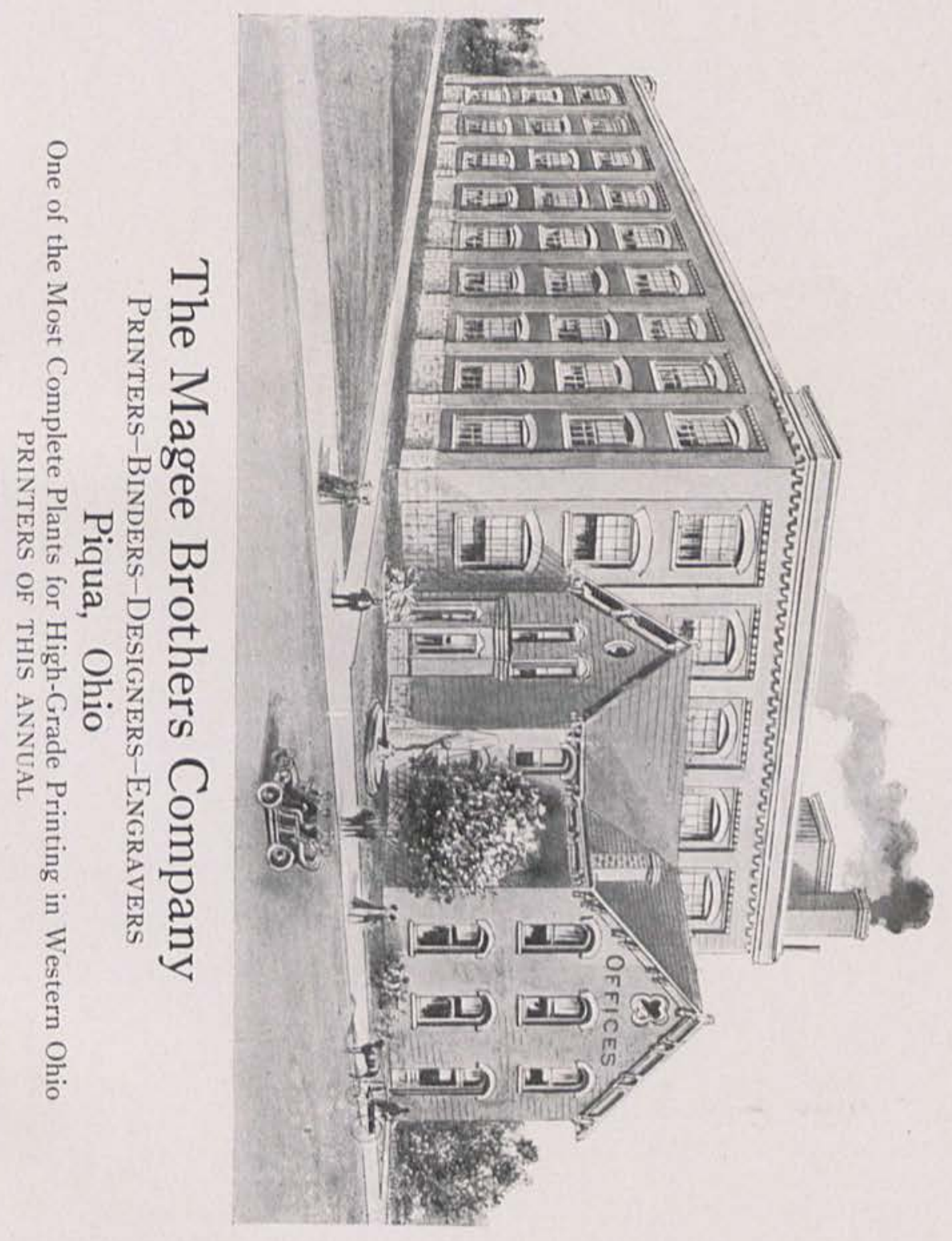




